\title{
Map Depicting Susceptibility to Landslides Triggered by Intense Rainfall, Puerto Rico
}

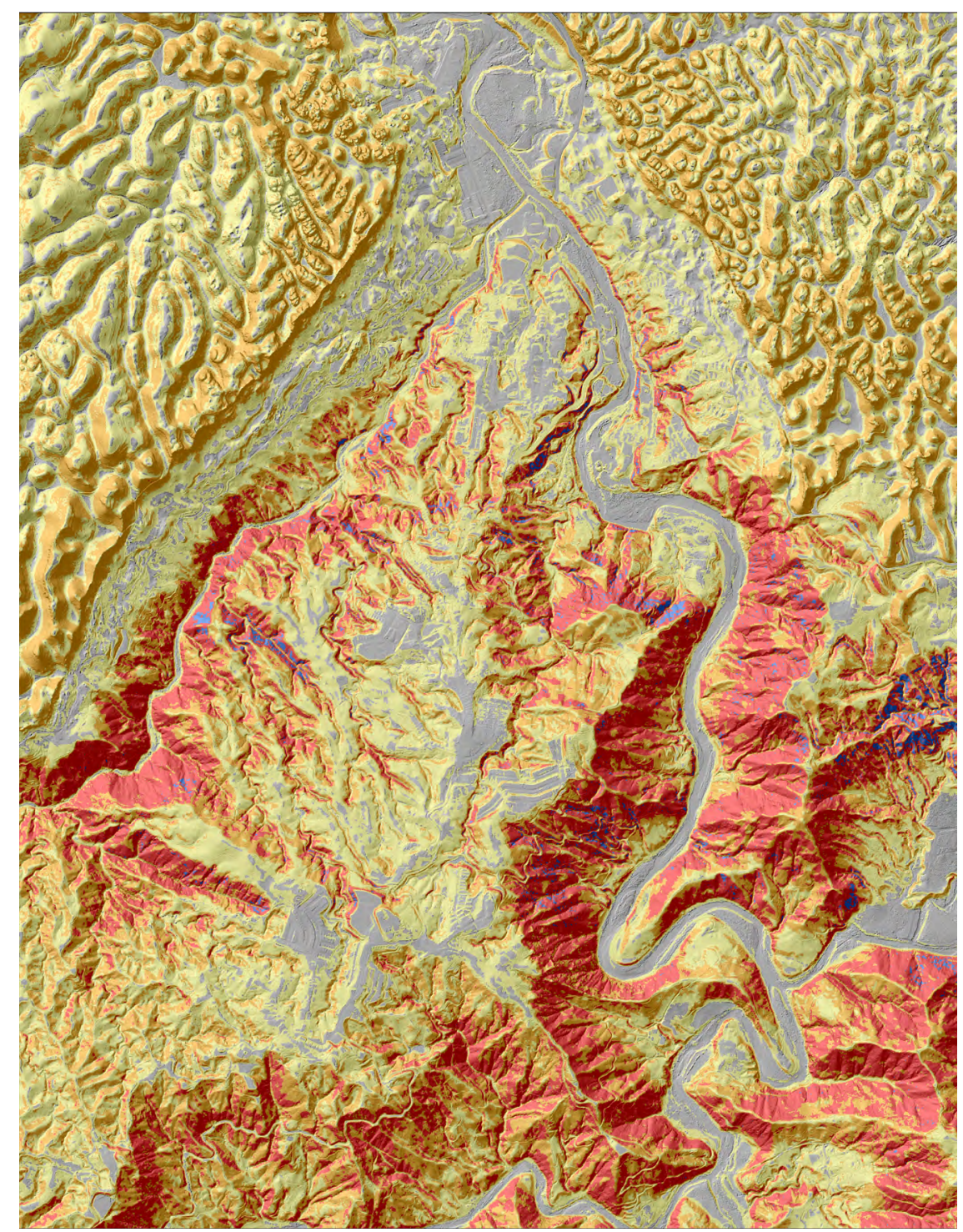

Open-File Report 2020-1022 
Cover. View from the landslide susceptibility map (plate 1) along the border between Ciales and Morovis municipalities, Puerto Rico. 


\section{Map Depicting Susceptibility to Landslides Triggered by Intense Rainfall, Puerto Rico}

By K. Stephen Hughes and William H. Schulz

Landslide Hazards Program

Open-File Report 2020-1022 


\title{
U.S. Department of the Interior DAVID BERNHARDT, Secretary
}

\author{
U.S. Geological Survey \\ James F. Reilly II, Director
}

\section{U.S. Geological Survey, Reston, Virginia: 2020}

For more information on the USGS - the Federal source for science about the Earth, its natural and living resources, natural hazards, and the environment-visit https://www.usgs.gov or call 1-888-ASK-USGS.

For an overview of USGS information products, including maps, imagery, and publications, visit https://store.usgs.gov.

Any use of trade, firm, or product names is for descriptive purposes only and does not imply endorsement by the U.S. Government.

Although this information product, for the most part, is in the public domain, it also may contain copyrighted materials as noted in the text. Permission to reproduce copyrighted items must be secured from the copyright owner.

Suggested citation:

Hughes, K.S., and Schulz, W.H., 2020, Map depicting susceptibility to landslides triggered by intense rainfall, Puerto Rico: U.S. Geological Survey Open-File Report 2020-1022, 91 p., 1 plate, scale 1:150,000, https://doi.org/10.3133/ofr20201022.

Associated data for this publication:

Hughes, K.S., and Schulz, W.H., 2020, Results from frequency-ratio analyses of soil classification and land use related to landslide locations in Puerto Rico following Hurricane María: U.S. Geological Survey data release, https://doi.org/10.5066/P9VK2FAL.

ISSN 2331-1258 (online) 


\section{Acknowledgments}

The authors thank many colleagues and partners for their direct and indirect support of this project. K. Stephen Hughes (KSH) acknowledges the dedication of a terrific group of students in the Department of Geology at the University of Puerto Rico at Mayagüez who worked diligently to manually identify tens of thousands of landslide headscarps in aerial photographs taken across Puerto Rico after Hurricane María. These students include Sahira Cancel, Xavier García, Selena González, Edwin Irizarry, Raquel Lugo, Priscilla Ortiz, César Rodríguez, Amos Santiago, Yanira Santiago, Stephanie Soto, and Karla Torres. Additional support was provided by U.S. Department of Agriculture Natural Resource Conservation Service personnel Luis Aponte, Brendaly Rodríguez, and Misha Vargas. Special thanks to team members Desireé Bayouth and Gabriel Martínez who performed the tedious final verification of all landslide sites across the island. KSH is grateful to Chiara Lepore for sharing her previous susceptibility analysis data. $\mathrm{KSH}$ also thanks colleague James Joyce for helpful counsel in the subject matter in addition to the University of Puerto Rico at Mayagüez College of Arts and Sciences for providing release time to devote to the project.

KSH and William H. Schulz thank Arleen Reyes Rodriguez and Félix Rivera Santiago of the Puerto Rico Planning Board for their suggestions and assistance while developing the susceptibility map. Both authors also wish to thank Jim Hibbard and Félix Rivera Santiago for thoughtful and constructive review of the report. Desireé Bayouth is thanked for translating the report into Spanish. Both authors also thank Rex Baum, Jeffrey Coe, Eric Jones, and Robert Schmitt of the U.S. Geological Survey for their suggestions and assistance while developing the susceptibility map. Rex Baum and Jeffrey Coe are also thanked for their thoughtful and constructive review of the report. 


\section{Contents}

Acknowledgments .........................................................................................................................

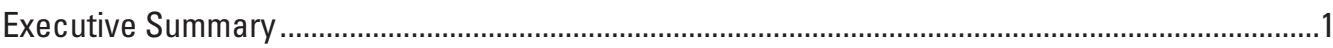

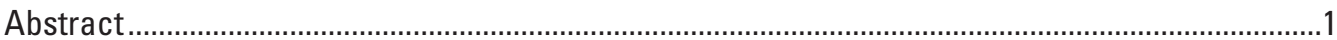

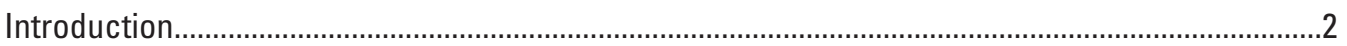

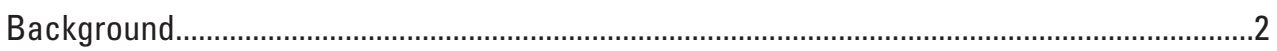

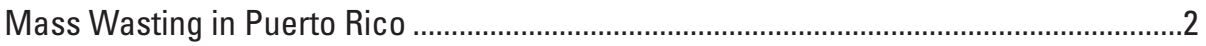

General Geology of Puerto Rico ..................................................................................11

Natural Landslide-Provoking Phenomena in Puerto Rico ..................................................11

Anthropogenic Topographic Perturbations .....................................................................12

Previous Landslide Susceptibility Studies for Puerto Rico ......................................................12

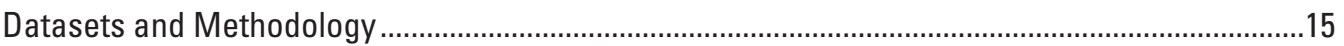

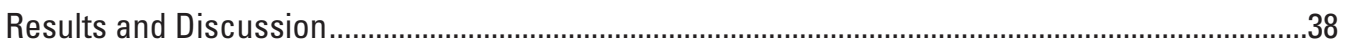

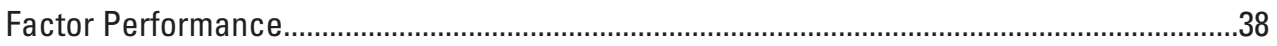

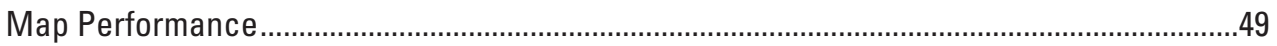

Use and Limitations of the Landslide Susceptibility Map .......................................................64

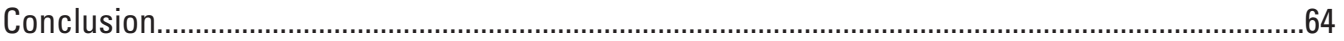

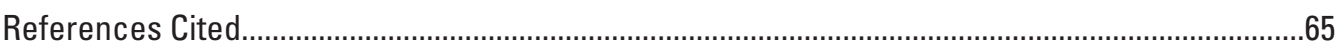

Appendix 1. Key for Municipality Abbreviations .........................................................................73

Appendix 2. Results from Analyses of Land Cover....................................................................74

Appendix 3. Results from Analyses of Soil Class ...........................................................................

\section{Figures}

1. Map showing the topography of the U.S. territory of Puerto Rico

2. Photograph of the headscarp and body of the large block landslide in 1985 at Mameyes, Ponce, Puerto Rico ...................................................................................... 4

3. Photograph of a large block landslide along Highway PR-9 in Ponce, Puerto Rico ........5

4. Photograph of a large block failure along uncompleted section of PR-385 in Peñuelas, Puerto Rico

5. Photograph of debris flows triggered by Hurricane Georges along the Rio Grande de Arecibo in Utuado, Puerto Rico

6. Photograph of a landslide along Highway PR-4131 in the municipality of Lares, Puerto Rico

7. Photograph of abundant shallow mass movements and debris flows on the eastern side of the upper reach of Lago Caonillas, Puerto Rico.

8. Photograph of a landslide that transitioned to debris flow along Highway PR-143 in Barranquitas, Puerto Rico .

9. Photograph of a shallow failure in Río Blanco watershed of Naguabo, Puerto Rico

10. Hand-drawn landslide susceptibility map modified from Monroe (1979) ........................13

11. Landslide susceptibility map modified from Lepore and others (2012) 
12. Map of the Hurricane María event slope failure inventory ..............................................16

13. Map showing the density of landslide sites from the Hurricane María

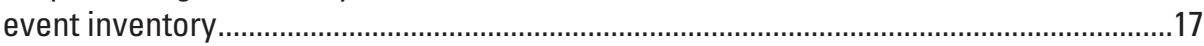

14. Flowchart depicting the process followed to develop the $S I A_{m}$ raster ..........................18

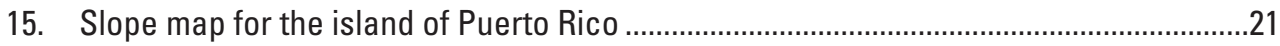

16. Map showing curvature values calculated from lidar-derived digital elevation

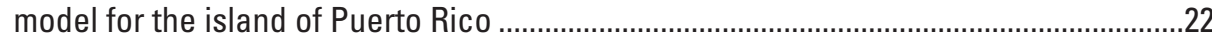

17. Map showing the missing zones for the 2015-2016 airborne lidar survey of Puerto Rico ... .27

18. Map showing paved roads on the island of Puerto Rico ….............................................28

19. Hillshade raster from a lidar-derived digital elevation model and aerial photograph of a dense improvised farm road network that is not digitized as part of the U.S. Census Bureau TIGER roads shapefile ...................................................29

20. Map showing digitized 1:20,000 geologic map units of Puerto Rico ...............................30

21. Map showing the mean annual precipitation in Puerto Rico .........................................31

22. Map of fluvial channels for Puerto Rico from the National Hydrography

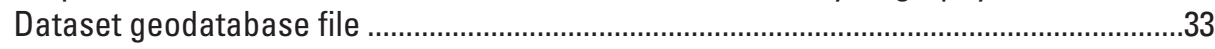

23. Map of the Puerto Rico Gap Analysis Program land cover dataset ................................34

24. U.S. Department of Agriculture Natural Resources Conservation Service soil classification map for the island of Puerto Rico .......................................................35

25. Map showing raw Soil Moisture Active Passive root zone soil moisture data for 9:30 a.m. Atlantic Standard Time on 21 September 2017.........................................36

26. Map showing interpolated Soil Moisture Active Passive root zone soil moisture data at 9:30 a.m. Atlantic Standard Time on 21 September 2017 .....................................37

27. Map and a graphical representation of the results of the slope Susceptibility Index analysis.

28. Map and a graphical representation of the results of the curvature Susceptibility Index analysis.

29. Map and a graphical representation of the results from the proximity to road factor

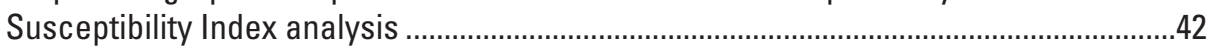

30. Map showing Susceptibility Index results for geological terranes ...............................43

31. Map and a graphical representation of the results from Susceptibility Index analysis of mean annual precipitation.

32. Map and a graphical representation of the results from Susceptibility Index analysis of the proximity to fluvial channel factor

33. Map of the results from analysis of Susceptibility Index values for the 66 unique

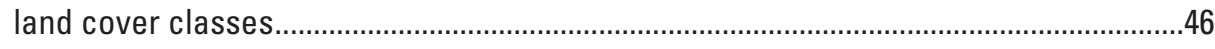

34. Map of the results from Susceptibility Index analysis of 697 soil classes......................47

35. Map of the results from Susceptibility Index analysis of Soil Moisture Active Passive data

36. Graph of receiver operating characteristic area under curve analyses for different combinations of data results

37. Composite Susceptibility Index map of the seven nonslope and non-Soil Moisture Active Passive datasets used in the analysis.

38. Map of residual values of Susceptibility Index model output from this study compared with the frequency ratio model output of a previous study. 
39. An example of the Susceptibility Index model output for the Santa Ana mogote landslide at the Villa España Urbanization in the municipality of Bayamón, Puerto Rico, including a hillshade raster of the 2016 lidar survey data, an aerial view of the same location, the final susceptibility map dataset overlayed on the hillshade raster, the final susceptibility map dataset overlayed on the aerial imagery, an oblique aerial photograph of the site in 2013, and a location map of the area.....

40. Example of the Susceptibility Index model output for the Las Lomas Urbanization failure in the municipality of Ceiba, Puerto Rico, including a hillshade raster of the 2016 lidar survey data, an aerial view of the same location, the final susceptibility map dataset overlayed on the hillshade raster, the final susceptibility map dataset overlayed on the aerial imagery, a photograph of the headscarp, and a location map of the area

41. Example of the Susceptibility Index model output for the PR-143 kilometer 56.2 landslide site in the municipality of Barranquitas, Puerto Rico, including a hillshade raster of the 2016 lidar survey data, an aerial view of the same location, the final susceptibility map dataset overlayed on the hillshade raster, the final susceptibility map dataset overlayed on the satellite imagery, a photograph of the headscarp, and a location map of the area.

42. Example of the Susceptibility Index model output for a landslide in the urban center of Utuado, Puerto Rico, caused by Hurricane María, including a hillshade raster of the 2016 lidar survey data, an aerial view of the same location, the final susceptibility map dataset overlayed on the hillshade raster, the final susceptibility map dataset overlayed on the aerial imagery, a photograph of the site, and a location map

43. Example of the Susceptibility Index model output for a landslide at kilometer 209.3 along Highway PR-2 in the municipality of Guayanilla, Puerto Rico, including a hillshade raster of the 2016 lidar survey data, an aerial view of the same location, the final susceptibility map dataset overlayed on the hillshade raster, the final susceptibility map dataset overlayed on the aerial imagery, a photograph of the site, and a location map...

\section{Tables}

1. Hypothetical examples of a set of frequency-ratio values and corresponding Susceptibility Index values for a given bin of any characteristic..

2. Data utilized in the frequency-ratio analyses...

3. Results from frequency-ratio analyses of potential landslide-contributing factors .......23

4. Susceptibility Index values for potential landslide-contributing factors

5. Results from comparison of the susceptibility map to locations of landslides in the Hurricane María inventory ....................................................................................4

6. Factors considered in quantitative Puerto Rico landslide susceptibility maps ................53

7. Comparison of performance of Puerto Rico landslide susceptibility maps against the Hurricane María inventory. 


\section{Conversion Factors}

U.S. customary units to International System of Units

\begin{tabular}{lcc}
\hline Multiply & By & To obtain \\
\hline acre & Area & \\
\hline
\end{tabular}

International System of Units to U.S. customary units

\begin{tabular}{lcc}
\hline \multicolumn{1}{c}{ Multiply } & By & To obtain \\
\hline centimeter $(\mathrm{cm})$ & Length & \\
millimeter $(\mathrm{mm})$ & 0.3937 & inch (in.) \\
meter $(\mathrm{m})$ & 0.03937 & inch (in.) \\
kilometer $(\mathrm{km})$ & 3.281 & foot $(\mathrm{ft})$ \\
& 0.6214 & mile (mi) \\
\hline square kilometer $\left(\mathrm{km}^{2}\right)$ & Area & acre \\
\hline & 247.1 & gallon $(\mathrm{gal})$ \\
\hline cubic meter $\left(\mathrm{m}^{3}\right)$ & Volume & million gallons $\left(\mathrm{Mgal}^{3}\right)$ \\
cubic meter $\left(\mathrm{m}^{3}\right)$ & 264.2 & cubic foot $\left(\mathrm{ft}^{3}\right)$ \\
cubic meter $\left(\mathrm{m}^{3}\right)$ & 0.0002642 & cubic yard $\left(\mathrm{yd}^{3}\right)$ \\
cubic meter $\left(\mathrm{m}^{3}\right)$ & 35.31 & \\
\hline
\end{tabular}

\section{Datum}

Horizontal coordinate information is referenced to the World Geodetic System of 1984 (WGS84). 


\section{Abbreviations}

$\circ$

AUC area under curve

DEM digital elevation model

FR frequency ratio

GAP Gap Analysis Program

GIS geographic information system

KSH K. Stephen Hughes

lidar light detection and ranging

MUKEY mapunit key

NASA National Aeronautics and Space Administration

ROC receiver operating characteristic

SI Susceptibility Index

SIA aggregate S/value

$S I A_{m} \quad$ the final modified $S /$ value at each 5-meter pixel islandwide

SMAP Soil Moisture Active Passive

USGS U.S. Geological Survey 


\title{
Map Depicting Susceptibility to Landslides Triggered by Intense Rainfall, Puerto Rico
}

\author{
By K. Stephen Hughes, ${ }^{1}$ and William H. Schulz ${ }^{2}$
}

\section{Executive Summary}

Puerto Rico is vulnerable to landsliding. This report summarizes creation of a new high-resolution model of rainfall-induced landslide susceptibility for the main island. The main island of Puerto Rico was classified at 5-meter pixel scale into categories of Low, Moderate, High, Very High, or Extremely High susceptibility to landsliding during and soon after intense rainfall, such as is produced during tropical cyclones. The map data can be downloaded as georeferenced files in multiple formats by the public or government agencies and used in a geographic information system platform. The model is intended for use in planning, development, and emergency management. The map highlights areas susceptible to landsliding that may warrant further site-specific evaluation by licensed professionals.

This map product highlights an important collaboration between the U.S. Geological Survey and the Department of Geology at the University of Puerto Rico at Mayagüez that materialized after the destructive Hurricanes Irma and María in September 2017. An inventory of more than 70,000 mass wasting sites triggered by Hurricane María represents one of the initial products of this partnership and was an essential dataset in the modeling effort described in the report. Characteristics of the inventoried sites were statistically analyzed to produce Susceptibility Index values for various geospatial factors that were combined to form the new map product. The model output demonstrates how post-disaster data can be used to better understand risks and hazards for the future. The project benefited from diverse feedback among colleagues in the U.S. Geological Survey, at the University of Puerto Rico at Mayagüez, and government agencies in Puerto Rico. In addition, the inventory and present study satisfy sections (a), (b), (c), (d), and (i) of Article 4 in Puerto Rico Law 24 of 2008-Protocol for the Mitigation of Landslide Risks in Puerto Rico. The susceptibility map also represents an important step in understanding erosion, sedimentation, and hazards that arise from heavy rainfall in Puerto Rico and the tropics.

\section{Abstract}

Landslides in Puerto Rico range from nuisances to deadly events. Centuries of agricultural and urban modification of the landscape have perturbed many already unstable hillsides on the tropical island. One of the main triggers of mass wasting on the island is the high-intensity rainfall that is associated with tropical atmospheric systems. Puerto Rico's geographic position and rugged topography render millions of residents vulnerable to widespread landslide events. In this study, a high-resolution (5 meters), high-intensity rainfallinduced landslide susceptibility model was produced using the frequency-ratio method. Datasets utilized in the model included a complete-island landslide inventory created from imagery obtained after Hurricanes Irma and María impacted the island during September 2017, slope inclination, land-surface curvature, soil type, geologic terrane, mean annual precipitation, land use, soil moisture, and distance to roadways and streams. The final data product (plate 1) is a statistically viable representation of where landslides are likely to initiate during or soon after intense rainfall, with a robust receiver operating characteristic area-under-curve value of 0.87 . The model output raster pixel values were binned into 100 equal-area quantiles and then classified into Low, Moderate, High, Very High, and Extremely High classes of susceptibility. The Extremely High susceptibility classification represents the most vulnerable 1 percent of the island, whereas Very High, High, Moderate, and Low classifications cover 9, 20, 30, and 40 percent of the island, respectively. The susceptibility map is intended to assist in planning future development, mitigation measures, and post-event emergency response; however, it is not a substitute for site-specific, slope-stability assessments performed by licensed geologists and engineers. Additionally, the map does not portray locations where landslide material may travel after mobilization, and which may be at extreme risk; nor does it necessarily portray where landslides may occur during earthquakes or mass wasting triggered by prolonged, relatively low-intensity rainfall.

${ }^{1}$ University of Puerto Rico, Mayagüez, Puerto Rico.

${ }^{2}$ U.S. Geological Survey. 


\section{Introduction}

Puerto Rico $\left(18.25^{\circ} \mathrm{N} ., 66.50^{\circ} \mathrm{W}\right.$.) is an approximately 9,000-square kilometers $\left(\mathrm{km}^{2}\right)$ Caribbean territory of the United States and is the easternmost island of the Greater Antilles archipelago. Home to more than 3 million citizens, the archipelago's population density is the fourth highest of any U.S. State or State-equivalent jurisdiction, behind only the District of Columbia, New Jersey, and Rhode Island (U.S. Census Bureau, 2010). Unlike those locations, most of the Puerto Rican landscape is mountainous, a consequence of its location along the tectonically active North American-Caribbean plate boundary zone. A narrow, discontinuous coastal plain rings a rugged interior where the highest peaks on the main island are more than 1,300 meters (m) above sea level and lie within 150 kilometers $(\mathrm{km})$ of the more than 8,000 $\mathrm{m}$ deep Puerto Rico trench, which marks the plate boundary. The island's terrain is demarcated by the east-west trending Cordillera Central (fig. 1), which is the main north-south fluvial divide, and the Sierra de Luquillo that lies in the northeast corner of the territory. Because of the high-relief, rugged topography that covers most of the land surface, and relatively higher risk of tectonic or climatic conditions that can induce landslides, millions of residents in Puerto Rico are disproportionately more likely to suffer the effects of mass wasting than their counterparts in the continental United States (Jibson, 1987).

The purpose of the landslide susceptibility map product presented herein (plate 1) is to provide high-resolution (5-m pixel) hazard data that can be directly used by citizens and government agencies to assess and plan effectively for future extreme precipitation events that induce widespread slope failure across the main island of the territory. Given that long-term tropical cyclone forecasts predict more frequent high-intensity events that will likely directly affect Puerto Rico in the future (Knutson and others, 2010; Jennings and others, 2014; Keellings and Hernández Ayala, 2019; Ramos-Scharrón and Arima, 2019), this landslide susceptibility map can be used as a tool to potentially avoid the loss of life and property.

\section{Background}

\section{Mass Wasting in Puerto Rico}

Mass movements present persistent hazards in Puerto Rico. Landslides, rockfalls, slumps, debris flows, and other mass movements are responsible for the loss of human life, private property, transportation routes, utility infrastructure, and the temporary isolation of remote communities across the densely populated, rugged Caribbean island (for example, Jibson, 1987; Larsen, 2012; Bessette-Kirton and others, 2019). For this report, the term "landslide" is used to include all types of slope failure. The mountainous interior of the island is most at risk from landslides; however, landslides also present risks in an extensive karst province and coastal zones marked by steep cliffs and terraces. The 1985 landslide disaster at Mameyes in Ponce (fig. 2), which claimed at least 129 lives, serves as a reminder of the vulnerability to landslides on the island and remains the deadliest landslide event to have occurred in any jurisdiction of the United States (Jibson, 1986; Silva-Tulla, 1986). Large block landslides like the Mameyes example exist at other locations across the island (figs. 3 and 4), including Cerca del Cielo (Wang, 2012, 2013; Rivera Santiago, 2015), Lago Guajataca Dam (Monroe, 1967; Silva-Tulla and others, 2018); El Yunque (Wang and others, 2013), Highway PR-10 in Utuado (Rodriguez-Pérez and others, 1988; Deere and others, 1989), Highway PR-9 in Ponce (García López, 2018), and scattered along the southern karst escarpment (Monroe, 1964). Much more frequent and widespread are shallow mass movements that usually mobilize into fast-moving channelized debris flows that deliver sediment directly to the fluvial network (figs. 5-9; Campbell and others, 1985; Jibson, 1986, 1989; Larsen and Simon, 1990, 1993; Simon and others, 1990; Larsen and Torres Sánchez, 1992; Larsen and Santiago Román, 2001; Pando and others, 2005; Larsen, 2012; Hughes and Morales Vélez, 2017; Morales Vélez and Hughes, 2018; Silva-Tulla and others, 2018; Bessette-Kirton and others, 2019). The introduction of liberated sediment into a river system also has negative consequences related to sedimentation, especially in watersheds that have impounded reservoirs (for example, Soler-López, 2000; Rodríguez Feliciano and others, 2019). 


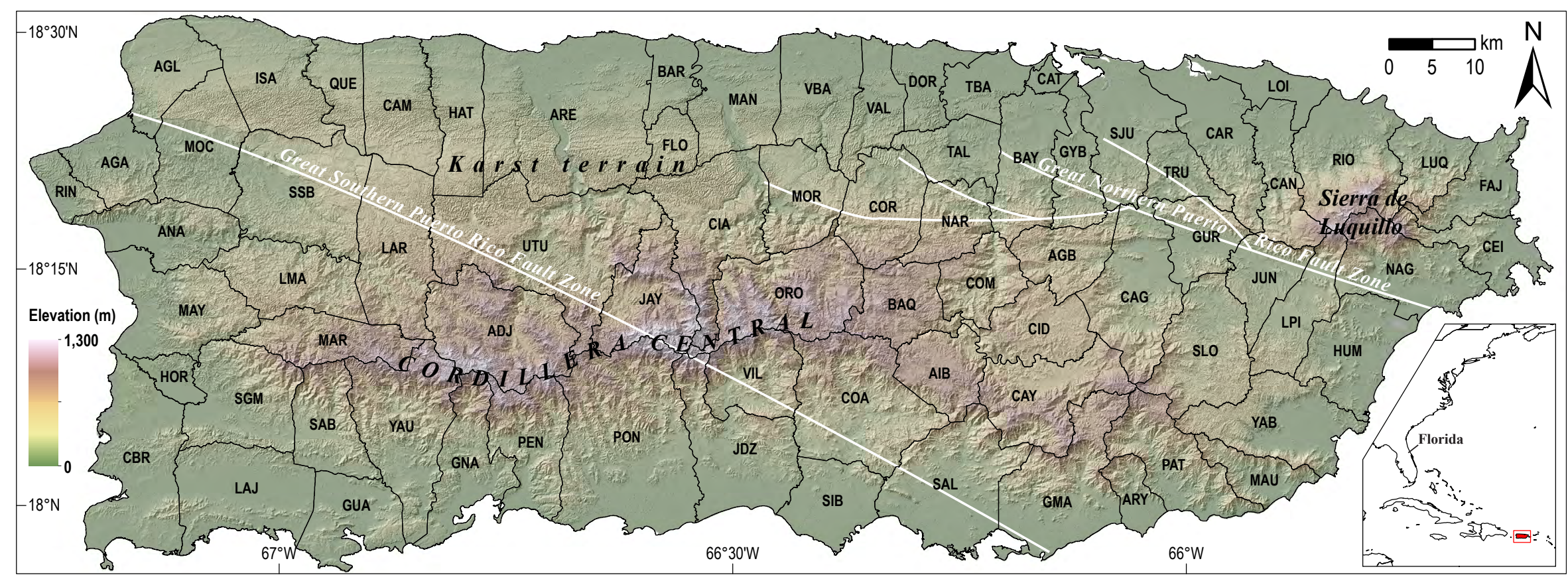

Figure 1. Topography of the U.S. territory of Puerto Rico (U.S. Geological Survey, 2017). The east-west trending Cordillera Central is the principal topographic feature on the island. It reaches more than 1,300 meters $(\mathrm{m})$ above sea level and is the primary drainage divide between rivers to the north that drain to the Atlantic 0cean and rivers to the south that drain to the Caribbean Sea. The north coast karst terrain covers about 20 percent of the island's surface. The prominent Sierra de Luquillo in eastern Puerto Rico is the site of El Yunque National Forest. Puerto Rico is the easternmost of the Greater Antilles archipelago and lies approximately 1,600 kilometers (km) southeast of the State of Florida (see inset). Approximate locations of the Great Northern and Great Southern Puerto Rico Fault Zones are modified from Zachariasen and von Hillebrandt-Andrade (2005). Explanation of municipality abbreviations can be found in appendix 1. 


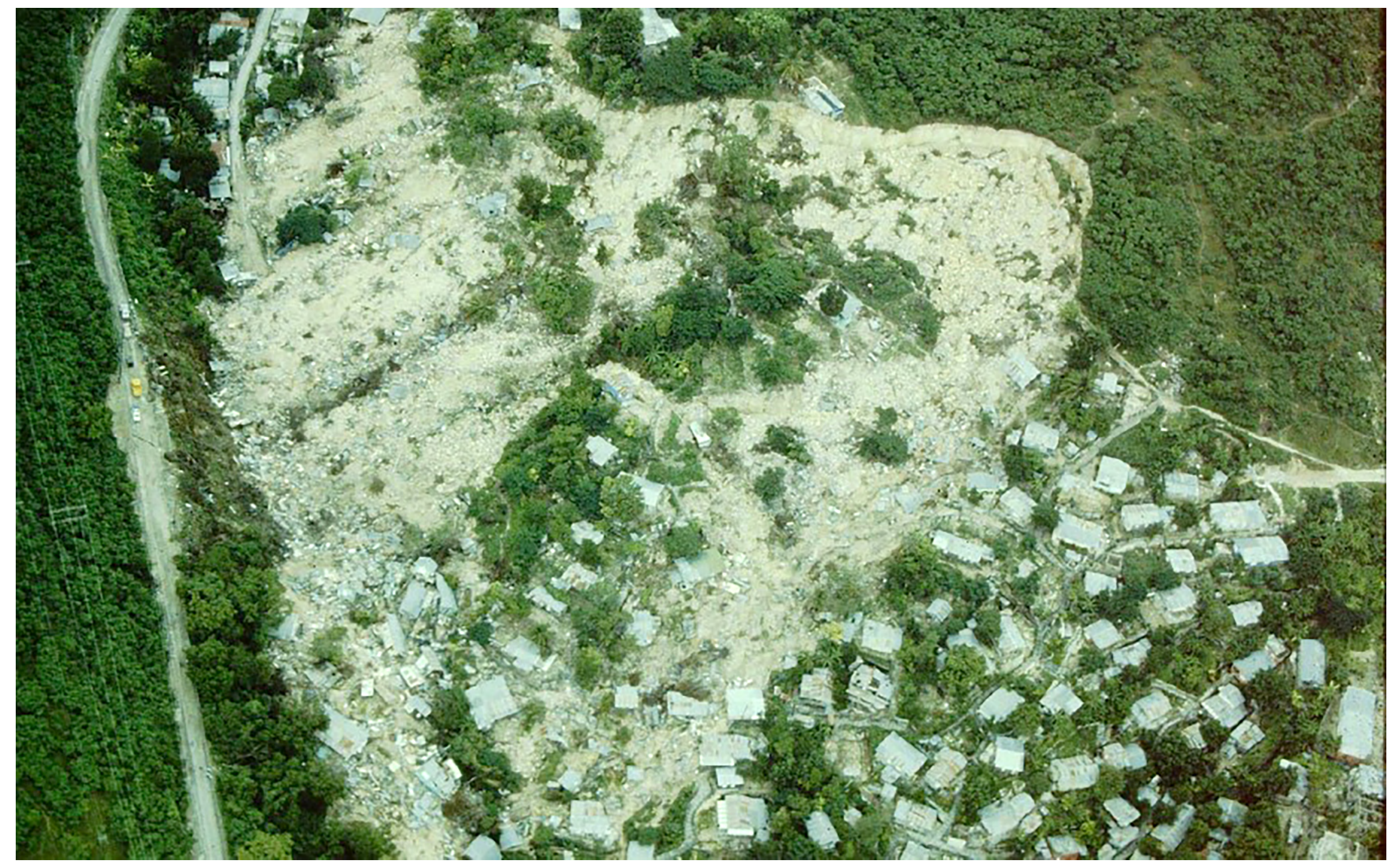

Figure 2. Headscarp and body of the large block landslide in 1985 at Mameyes, Ponce, Puerto Rico (18.024, -66.619). Photograph taken October 1985 by James Joyce, University of Puerto Rico at Mayagüez, used with permission. View is looking west. 


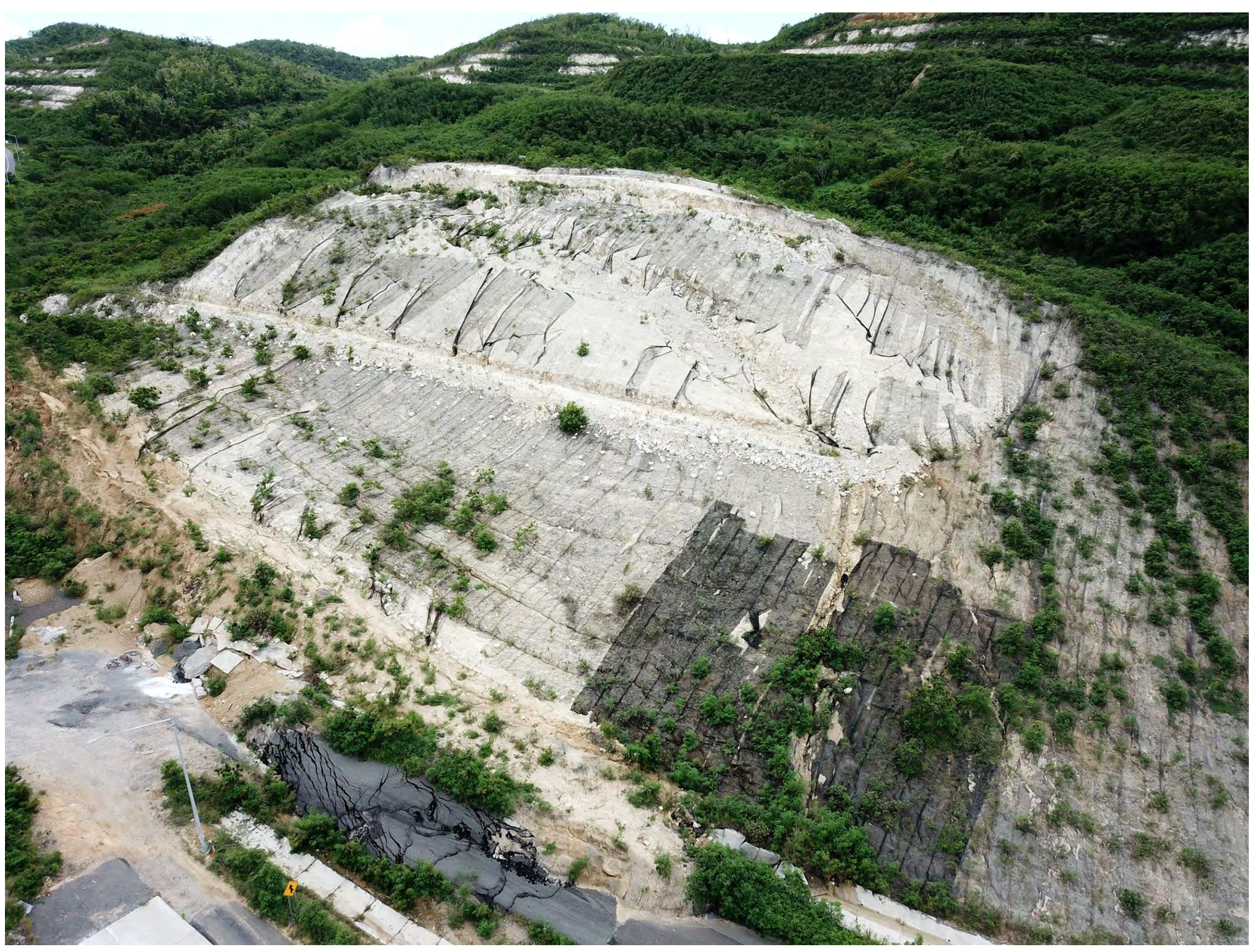

Figure 3. Large block landslide along Highway PR-9 in Ponce, Puerto Rico (18.032, -66.636). Photograph taken on 4 September 2018 by Stephen Hughes, University of Puerto Rico at Mayagüez. View is looking southeast. 


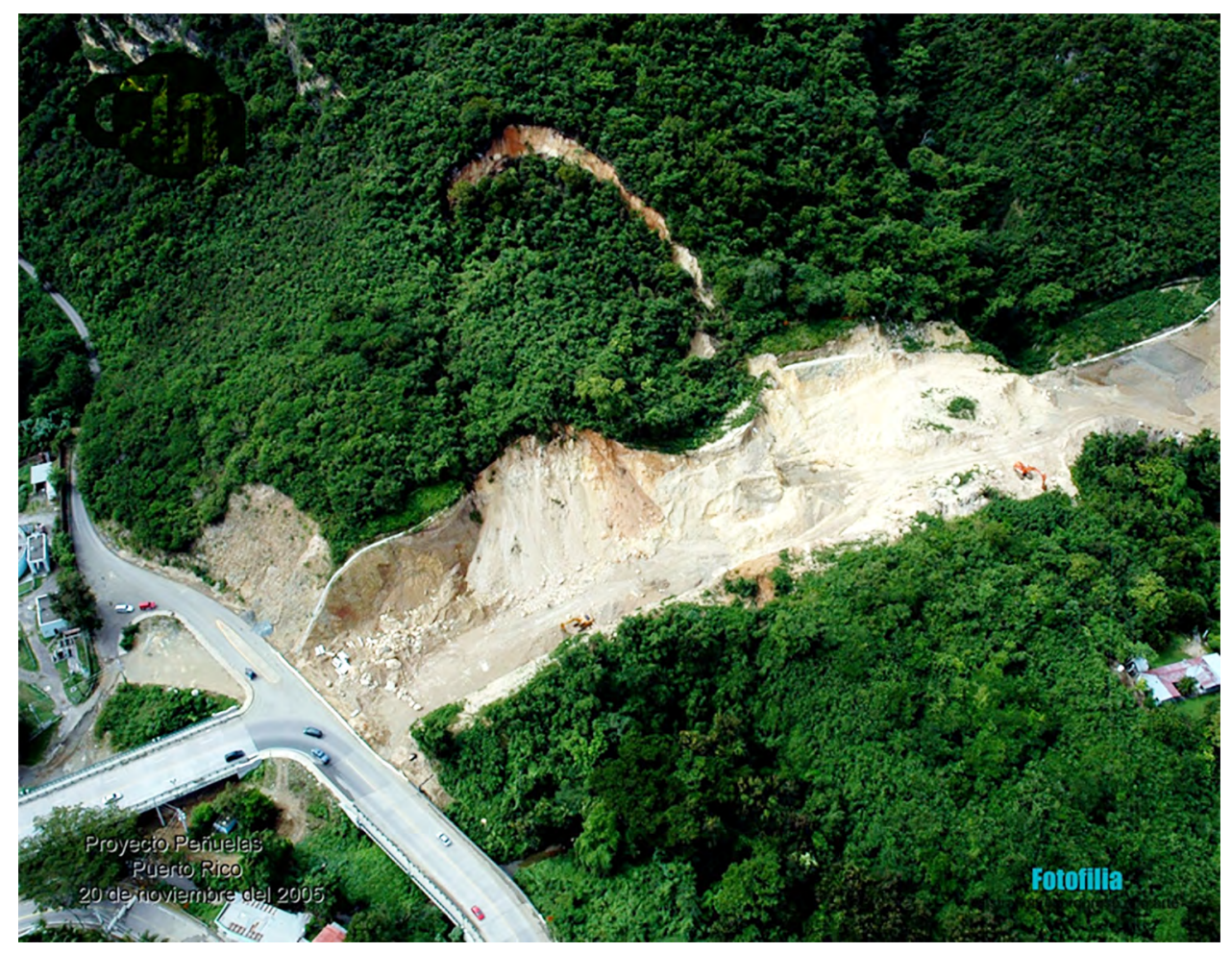

Figure 4. Large block failure along uncompleted section of PR-385 in Peñuelas, Puerto Rico (18.051, -66.724). Photograph taken by the Puerto Rico Autoridad de Carreteras y Transportación on 20 November 2005. View is looking south.

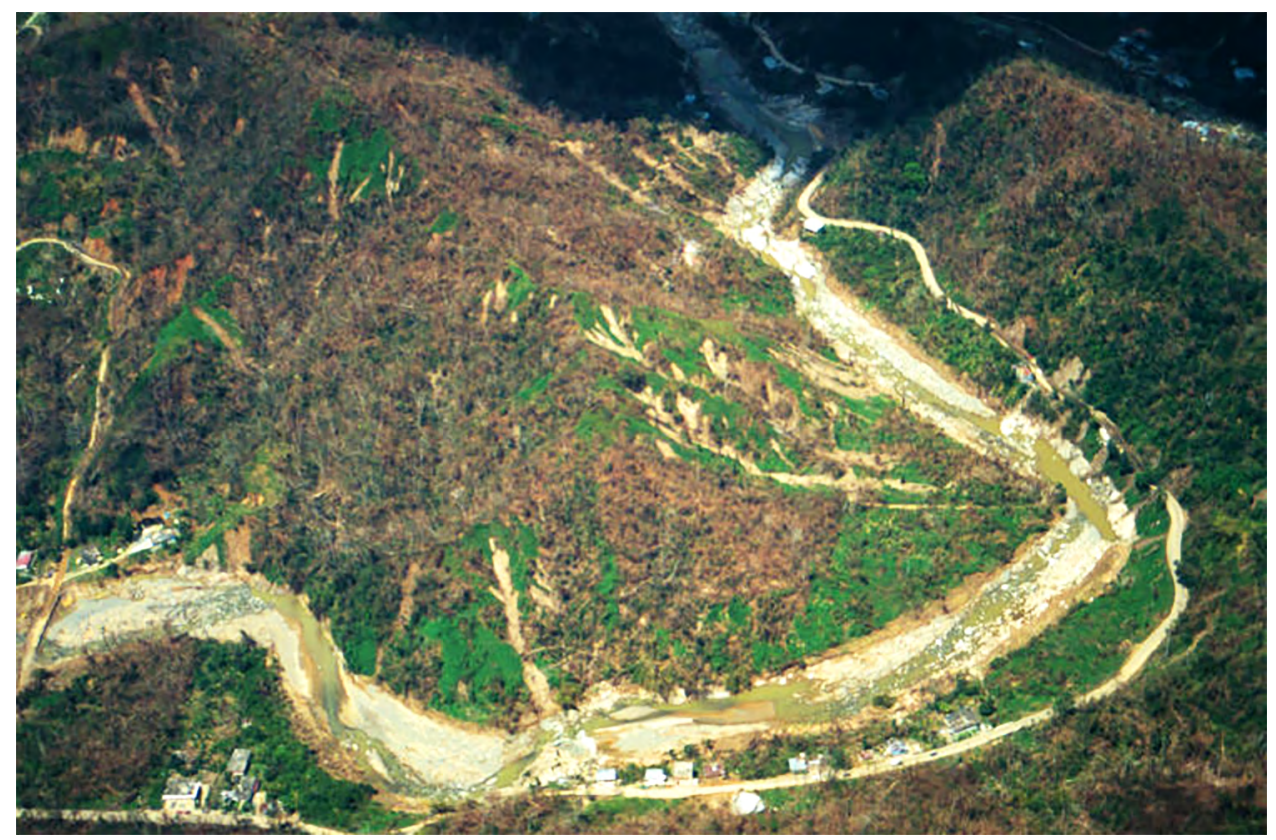

Figure 5. Debris flows (light-colored linear features on the hillslopes) triggered by Hurricane Georges along the Rio Grande de Arecibo in Utuado, Puerto Rico (18.222, -66.717). Photograph taken on 1 October 1998, courtesy of Cheryl Hapke, U.S. Geological Survey. View is looking north. 


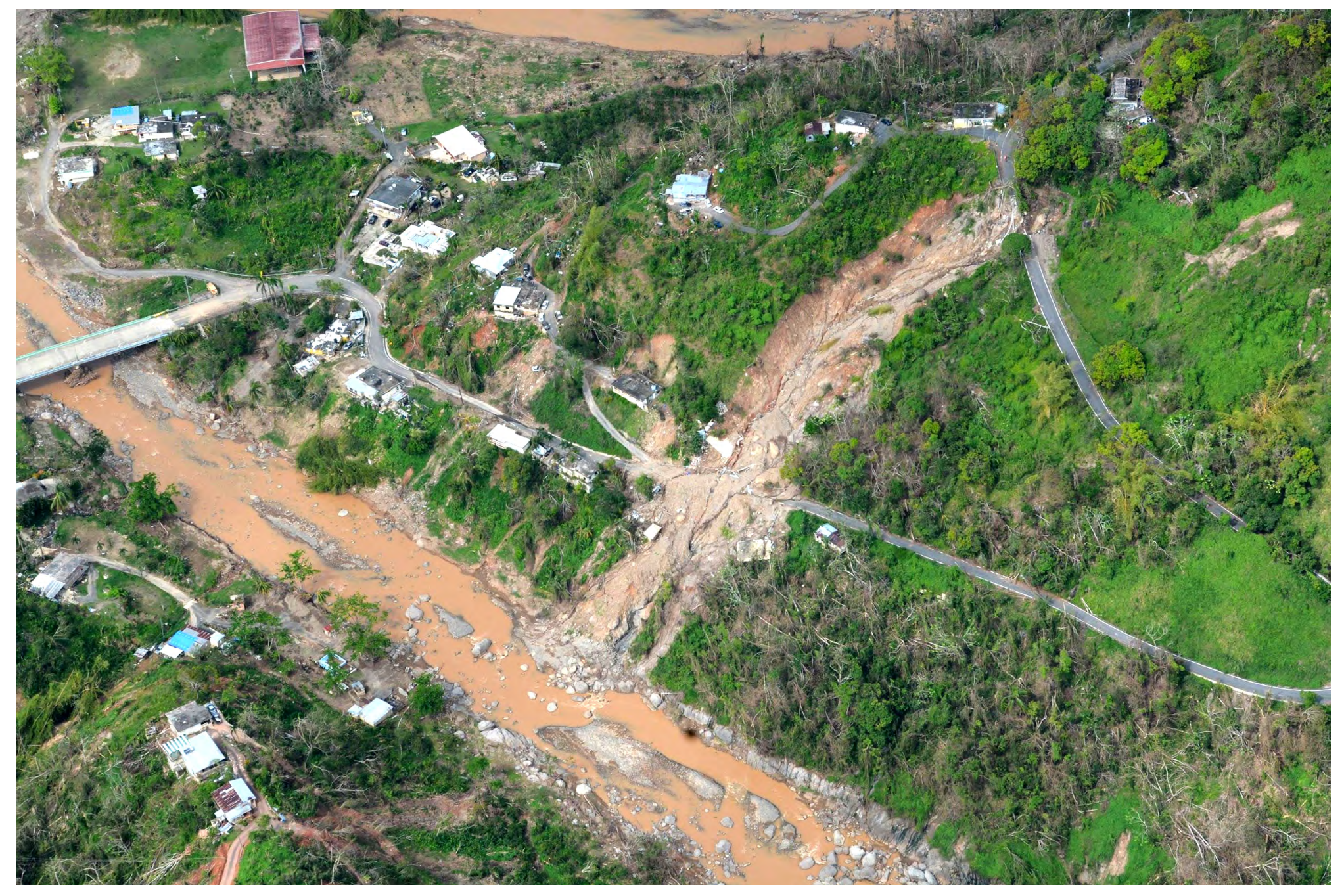

Figure 6. Landslide along Highway PR-4131 in the municipality of Lares, Puerto Rico $(18.250,-66.884)$. Photograph taken on 15 October 2017 by the Civil Air Patrol (2017). View is looking west. 


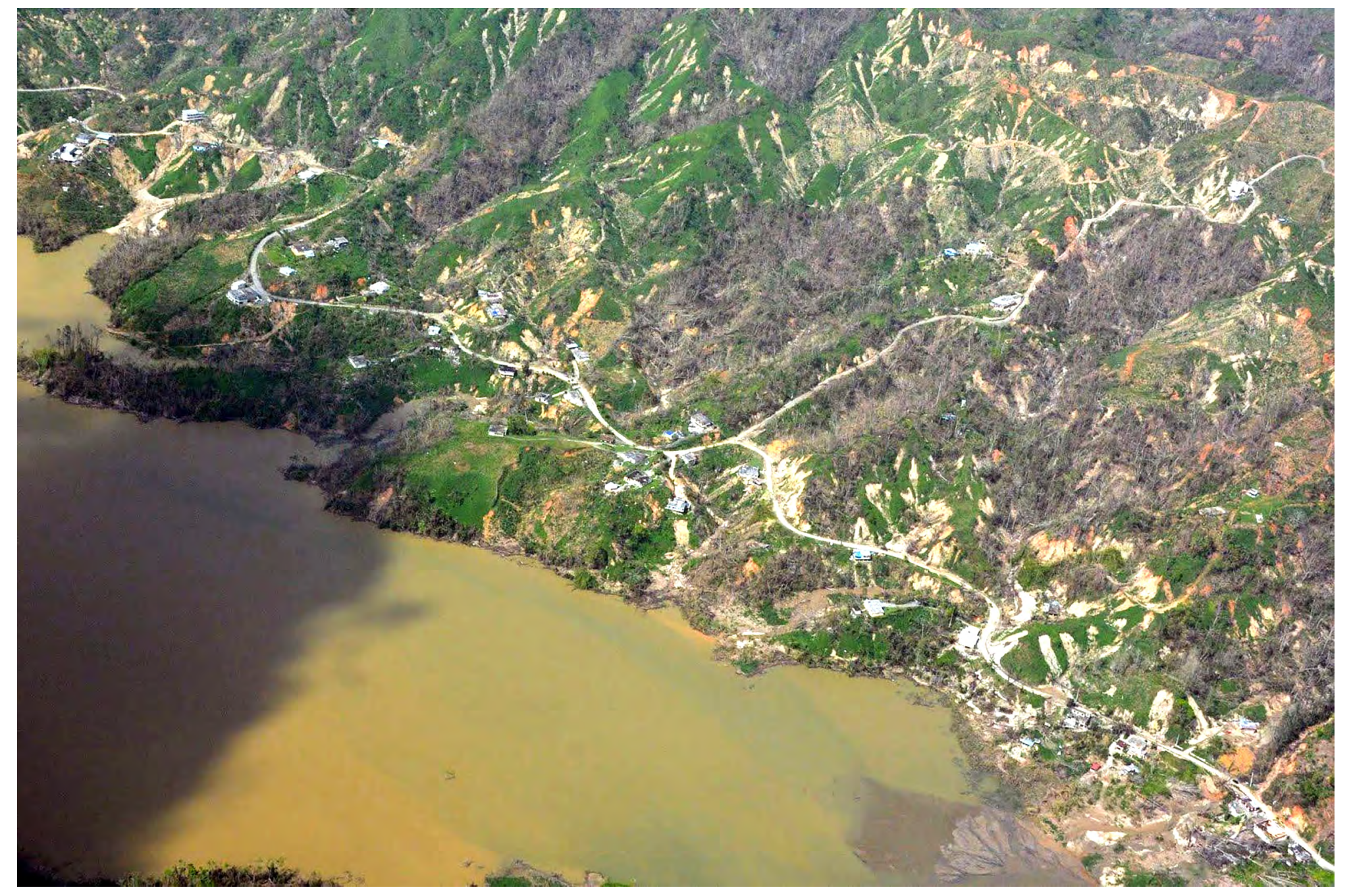

Figure 7. Abundant shallow mass movements and debris flows on the eastern side of the upper reach of Lago Caonillas, Puerto Rico (18.252, -66.644$)$. Photograph taken by the Civil Air Patrol (2017) on 17 October 2017. View is looking northeast. 


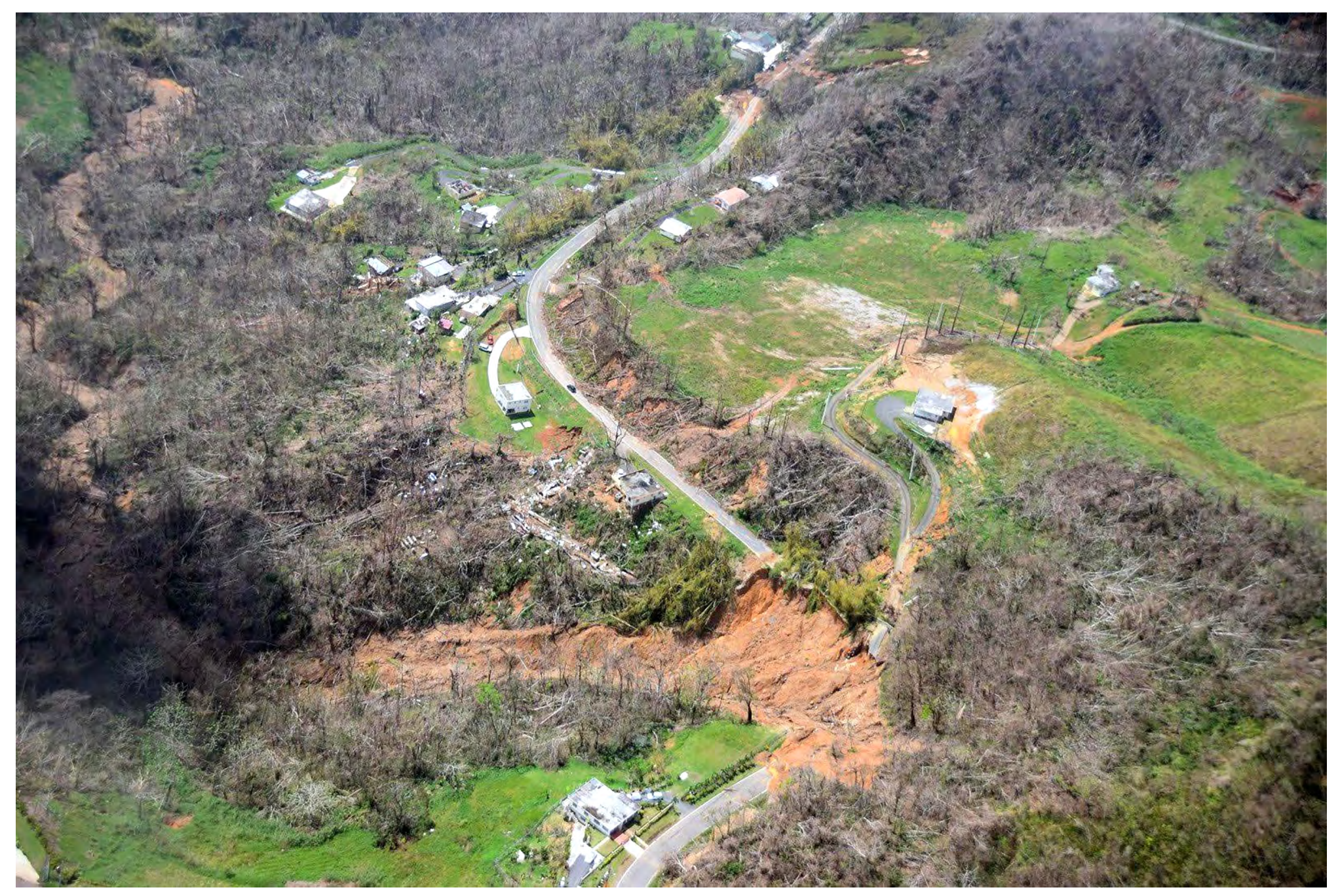

Figure 8. Landslide that transitioned to debris flow along Highway PR-143 in Barranquitas, Puerto Rico (18.176, -66.338). Photograph taken by the Civil Air Patrol (2017) on 12 October 2017. View is looking west. 


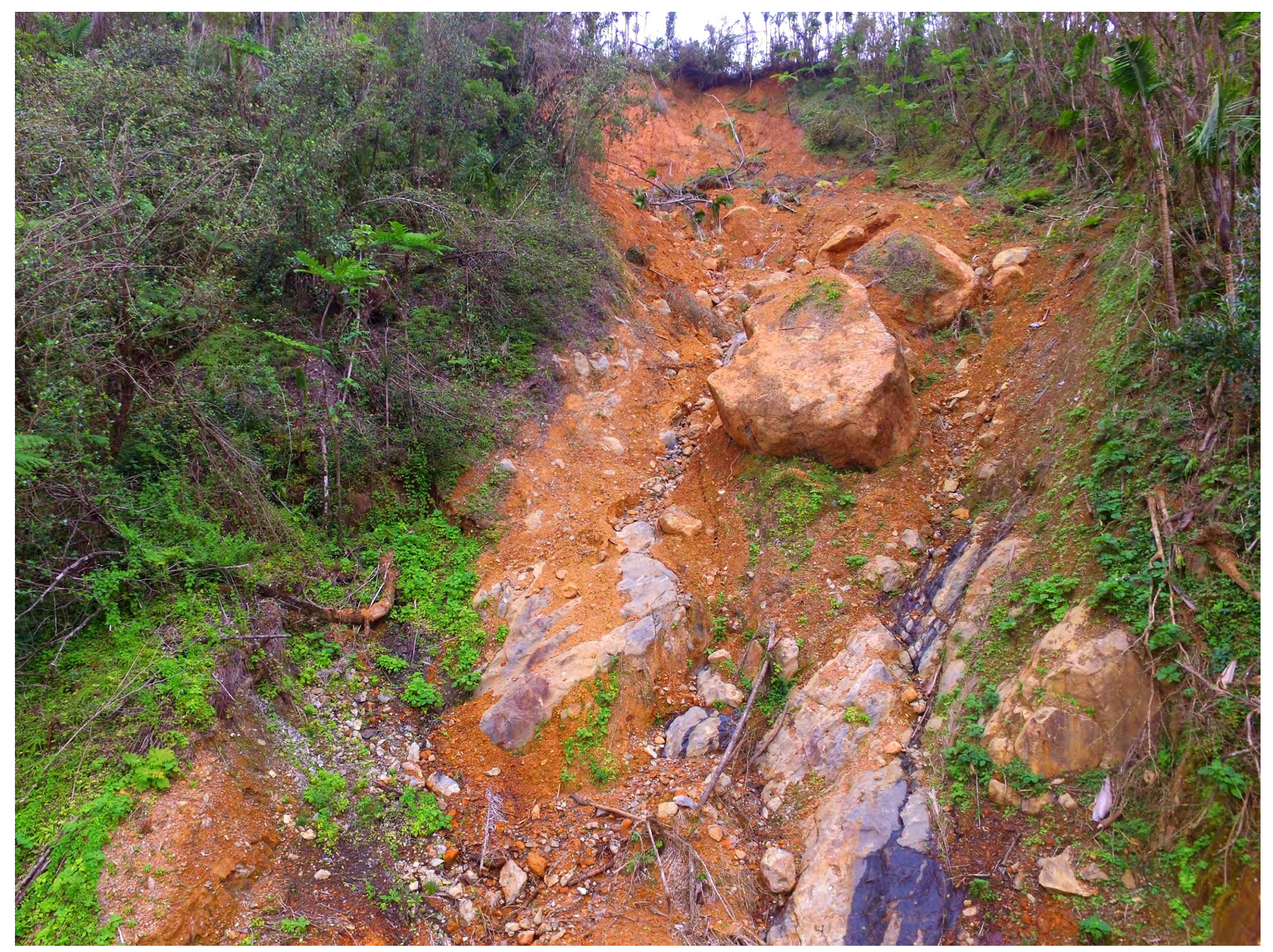

Figure 9. Shallow failure in Río Blanco watershed of Naguabo, Puerto Rico (18.266, -65.789). Photograph taken on 26 March 2018 by Stephen Hughes, University of Puerto Rico at Mayagüez. View is looking east-southeast. 


\section{General Geology of Puerto Rico}

The geology of the island is complex. In its simplest conceptualization, two main components include (1) an Eocene and older basement arc complex (Jolly and others, 1998a, 1998b) that is unconformably overlain by (2) a late Oligocene to Pliocene carbonate cover sequence (Monroe, 1980a; Ortega-Ariza and others, 2015). The basement rocks include volcaniclastic units, granodiorite plutons, serpentinite, and other rock types. Since the Pliocene, the island has experienced uplift, which continues to the present (Taggart and Joyce, 1989; Brocard and others, 2015); adjustment to this tectonic forcing has promoted topographic disequilibrium. Fluvial incision into low-relief erosional surfaces has shaped a deeply dissected landscape where hillslopes are oversteepened and drainage divides are susceptible to piracy. Erosion is also controlled in many places by the local bedrock geology. For example, karstification of carbonate rocks that underlie about 20 percent of the island has resulted in a topographic expression distinct from that of other geologic units on the island. In these karst zones, most water movement is subterranean, but elsewhere, surficial fluvial processes have exploited the abundance of faulted contacts in the island's older basement arc complex. Pronounced valley systems mark both the Great Northern and Southern Puerto Rico Fault Zones. Classic graben and half-graben fault systems are also expressed in the topography of western Puerto Rico (Grindlay and others, 2005; Mann and others, 2005; Prentice and Mann, 2005; Moul-Bogunovic, 2019). Chemical weathering is accelerated in most of the territory due to the prevalent humid tropical climate.

\section{Natural Landslide-Provoking Phenomena in Puerto Rico}

The island is particularly exposed to tropical cyclone activity because of its latitude and ocean setting. The most devastating atmospheric events to affect Puerto Rico usually originate near the Cape Verde islands in the eastern Atlantic Ocean and travel west-northwest towards the Lesser and Greater Antilles (Ramos-Scharron and Arima, 2019). The most destructive hurricanes that have affected Puerto Rico since U.S. occupation in 1898 are San Ciriaco (1899) and María (2017). Because of vast differences in the political and societal landscape of the island during each event, direct comparison of the impacts of the two storms is difficult. However, both storms caused historic flooding, destruction of infrastructure, extensive loss of cultivated lands, and loss of life. Hurricane San Ciriaco resulted in the death of more than 3,000 residents and left more than 200,000 residents of the total population of about 950,000 homeless and facing starvation (Sanger and others, 1900; Schwartz, 1992). Hurricane María also caused the death of an estimated 3,000 citizens and triggered the outmigration of about 8 percent (about 280,000 people) of the island population in the months after the storm (Milken Institute School of Public Health, 2018).

The archipelago lies at the seismically active interface of the North American and Caribbean tectonic plates. Widespread slope failures can also be triggered by seismic shaking. A swarm of earthquakes with magnitude as great as 6.4 occurred from December 2019 to January 2020 generally offshore of the Guanica municipality (fig. 1) and triggered rockfalls from steep slopes in limestone bedrock near the epicentral area (Lopez and others, 2020). Prior to this, the 1918 magnitude 7.2 Mona Passage earthquake (Doser and others, 2005) initiated mostly rockfalls that were generally reported in areas underlain by limestone bedrock units in the northwest portion of the island, closest to the inferred epicenter zone offshore (Reid and Taber, 1919). 


\section{Anthropogenic Topographic Perturbations}

Since colonization in the late 15th century, diverse societal factors in Puerto Rico have contributed to an increase in the failure susceptibility of hillslopes, many of which were already naturally vulnerable. During the 19th century under Spanish control, almost all of the usable Puerto Rican landscape was developed for agricultural crops such as sugarcane, coffee, and plantains (Dietz, 1986). In the decades after U.S. acquisition in 1898, a shift towards industrialization occurred, and in the latter 60 years of the 20th century, forests increased from only 10 percent coverage of the island to more than 40 percent (Grau and others, 2003). This statistic represents the abandonment of agricultural practices for the majority of the population and the movement towards urbanization. Both the agricultural and industrial phases of land use practice have involved extensive road networks. For the agrarian phase, a dense and tangled web of improvised roads was developed across montane plantations, and during the urbanization phase, construction of dense residential communities expanded into the hills and mountains surrounding population centers. Excavation and fill placement associated with road building throughout the development of the island has led to an increase in landslide susceptibility along and near roadways (for example, Larsen and Torres-Sanchez, 1992).

\section{Previous Landslide Susceptibility Studies for Puerto Rico}

Puerto Rico has been the focus of many landslide-related investigations given that it is a geographically, topographically, and climatologically unique jurisdiction under U.S. control. Puerto Rico-specific rainfall intensity thresholds have been empirically derived for historical storms that triggered widespread mass wasting (Larsen and Simon, 1993; Pando and others, 2005). Island-wide estimations of high landslide vulnerability zones have been carried out in the past at 1:240,000 and 1:60,000 scales (Monroe, 1979; Kamal, 2008; Lepore and others, 2012). Monroe's hand-drawn map (1979) was developed based upon extensive bedrock and surficial mapping carried out across the island and showcases zones susceptible to large and deep bedrock failures along prominent escarpments in the island's northern carbonate region (fig. 10). The vast majority of the interior of the island was classified as moderately susceptible, without much differentiation. Kamal (2008) and Lepore and others (2012) used a robust bivariate statistical method and partial landslide inventories available in central and eastern Puerto Rico to derive a susceptibility model (fig. 11) superior to Monroe's map (1979). The same general bivariate approach is used in this study, with modification.

Some regionally focused landslide susceptibility maps have been prepared for individual municipalities, including Ponce (PON; Larsen and others, 2004) and Comerío (COM; Larsen and Parks, 1998) at 1:30,000 and 1:20,000 scale, respectively. Both of these maps were prepared using a subjective matrix methodology and regional mass movement inventories. In addition, a seismic-triggered landslide susceptibility map was prepared for seven municipalities in the San Juan metropolitan area (TBA, CAT, BAY, SJU, GYB, CAR, and TRU; Santiago and Larsen, 2001). 


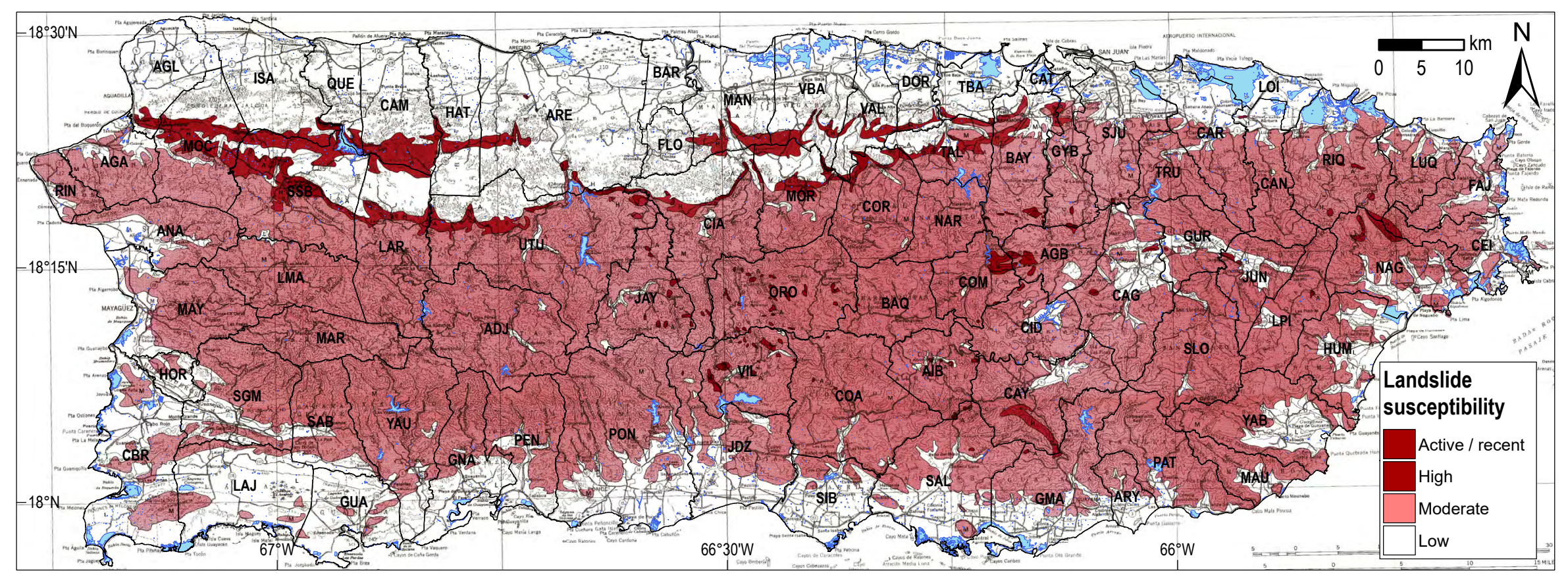

Figure 10. Hand-drawn landslide susceptibility map (1:240,000) modified from Monroe (1979). Most zones of active movement and high susceptibility lie within and at the margin of the northern carbonate province. Explanation of municipality abbreviations can be found in appendix 1. (km, kilometer) 


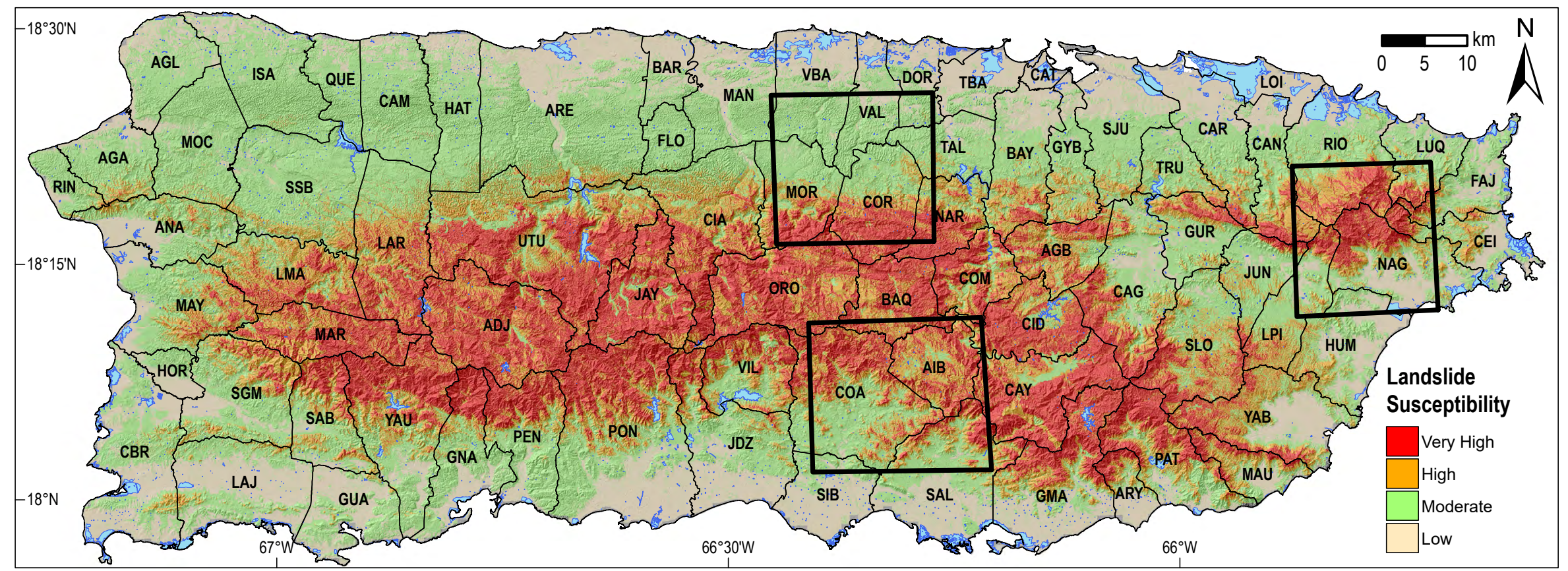

Figure 11. Landslide susceptibility map modified from Lepore and others (2012). Inventory areas used to inform their model are delineated by the three boxes. Explanation of municipality abbreviations can be found in appendix 1. (km, kilometer) 


\section{Datasets and Methodology}

The landslide susceptibility model described herein utilizes the Hurricane María digital landslide inventory (figs. 12 and 13; Hughes and others, 2019) as well as a host of other geospatial data. The inventory includes 71,431 points that correspond to the centers of headscarps formed at failure initiation sites. The sites were manually identified using high-resolution, georeferenced, post-event aerial and satellite imagery. The dataset appears to represent the largest rainfall-induced event slope failure inventory to date. The smaller municipalities of Culebra and Vieques that lie offshore of the main island were not incorporated in the model because they do not present considerable sites for slope failure and there were no landslides on these islands in the Hurricane María post-event inventory (Hughes and others, 2019). In addition, other minor outlying islands off the coast of Puerto Rico, including Caja de Muertos, Desecheo, Mona, and Monito, were not included in the analysis.

Various data in this study are classified by their correlation with María slope-failure sites and combined into a comprehensive model. The method employed is the frequency-ratio (FR) bivariate approach (Lee and Pradhan, 2006; Lee and others, 2007; He and Beighley, 2008; Lepore and others, 2012; Chalkias and others, 2014). Like other empirical assessments, FR analysis assumes that landslides are likely to occur in locations that have very similar conditions to previous failure sites (Brabb, 1984; Varnes, 1984; Sidle and Ochiai, 2006). The use of FR modeling requires that quantitative target factors (such as slope, curvature, aspect, and so on) are classified into ranges or bins. Then the percentage of total study area covered by that bin range is compared to the total percentage of events (landslides in this case) from some empirical dataset that are geospatially coincident with the locations where the bin range exists in the study area. A FR value for each bin $(i)$ of each characteristic $(f)$ is calculated using equation 1 (modified from He and Beighley, 2008; Lepore and others, 2012; and Chalkias and others, 2014):

$$
F R_{f i}=\frac{N_{L f} / N_{L}}{A_{f i} / A}
$$

where:

$F R_{f i}$ is the frequency-ratio value for each bin $(i)$ of each characteristic $(f)$,

$N_{L f} / N_{L} \quad$ is the ratio of the number of landslides in a bin (for example, slope of 0 degrees $\left[{ }^{\circ}\right]-5^{\circ}$ ) to the total number of landslides, and

$A_{f} / A \quad$ is the ratio of any area with the same bin characteristic to the total study area.

The value of $F R_{f i}$ is interpreted to indicate higher correlation of the event dataset to the geospatial factor dataset if it is greater than $1 . F R_{f i}$ values cannot be 0 or negative. Equation 2 was used to convert $F R_{f i}$ values to Susceptibility Index $(S I)$ values because equally opposite $F R_{f i}$ values are not symmetrically distributed about the neutral value of 1 :

$$
S I_{f i}=\ln \left(F R_{f i}\right)
$$

where:

$S I_{f i} \quad$ is the $S I$ value for each bin $(i)$ of each characteristic $(f)$.

Once converted to $S I$ values, the neutral value is now 0 , and negative numbers represent anti-correlation and positive numbers represent correlation between the event dataset and the geospatial factor dataset. Table 1 shows an example of hypothetical $F R_{f i}$ values converted to $S I_{f i}$ values. The use of $S I_{f i}$ values allows for the simple summing of classified factor raster datasets in the final model output.

Only a random 75 percent of the Hurricane María slope failure event inventory (Hughes and others, 2019) was used to calculate the $S I$ values for the landslide susceptibility model. The remaining 25 percent was used to examine the viability of the model using a receiver operating characteristic (ROC) curve (see "Results and Discussion" section). Although landslide inventories were created following other events (Jibson, 1989; Larsen and Torres-Sanchez, 1992), we were unable to obtain georeferenced versions of these inventories with which to test our model. We attempted to georeference the inventories from the publications, but results indicated inconsistent mislocations as great as several hundred meters between mapped landslides and their apparent true locations revealed by a light detection and ranging- (lidar-) derived digital elevation model (DEM; U.S. Geological Survey [USGS], 2017). Once the $S I$ values for each of the factors described below were calculated, they were combined using equation 3 to obtain an aggregate $S I$ value (SIA) for each pixel at 5-m resolution across the main island of Puerto Rico (fig. 14):

$$
S I A=\left(S I_{f 1}+S I_{f 1}+S I_{f 1}+S I_{f 4} \ldots\right)+X\left(S I_{f s}\right)
$$

where:

SIA is the aggregate $S I$ value,

$S I_{f n} \quad$ is the $S I$ value for nonslope factor $n$,

$X \quad$ is the number of nonslope factors, and

$S I_{f s} \quad$ is the $S I$ value for the slope factor. 


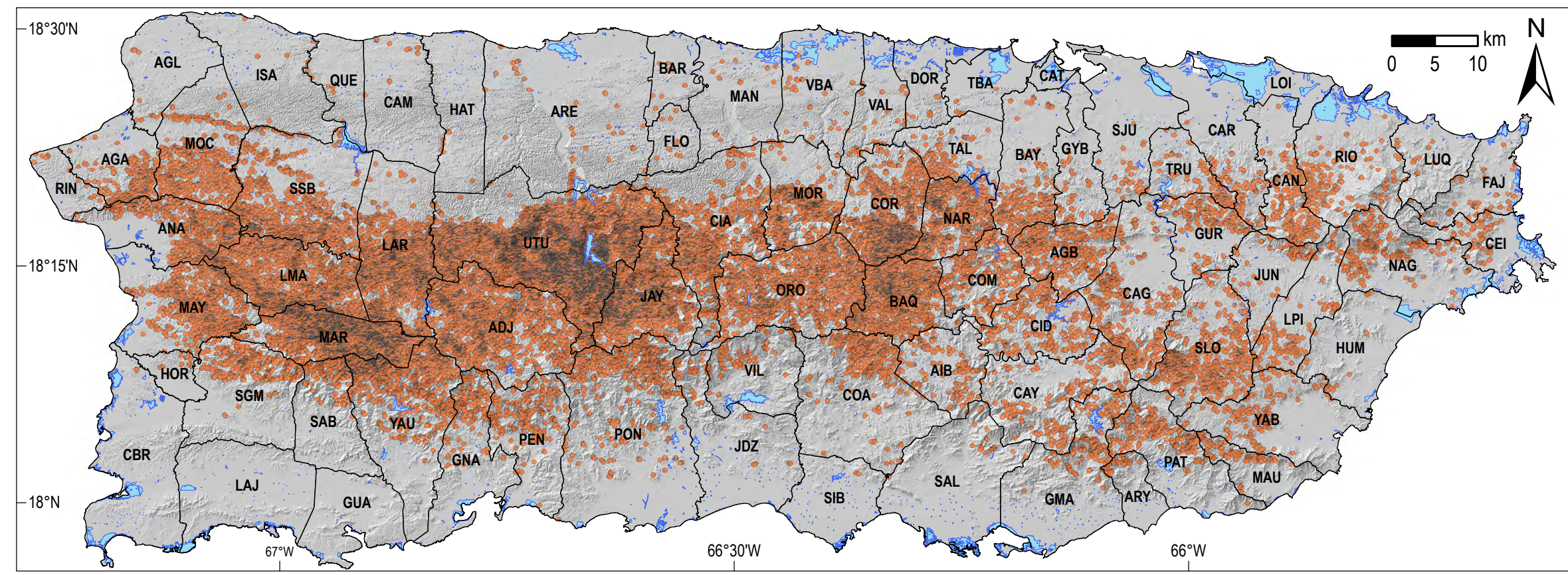

Figure 12. Hurricane María event slope failure inventory (Hughes and others, 2019). Each small circle represents one landslide site. There are 71,431 sites in the inventory. Explanation of municipality abbreviations can be found in appendix 1. (km, kilometer) 


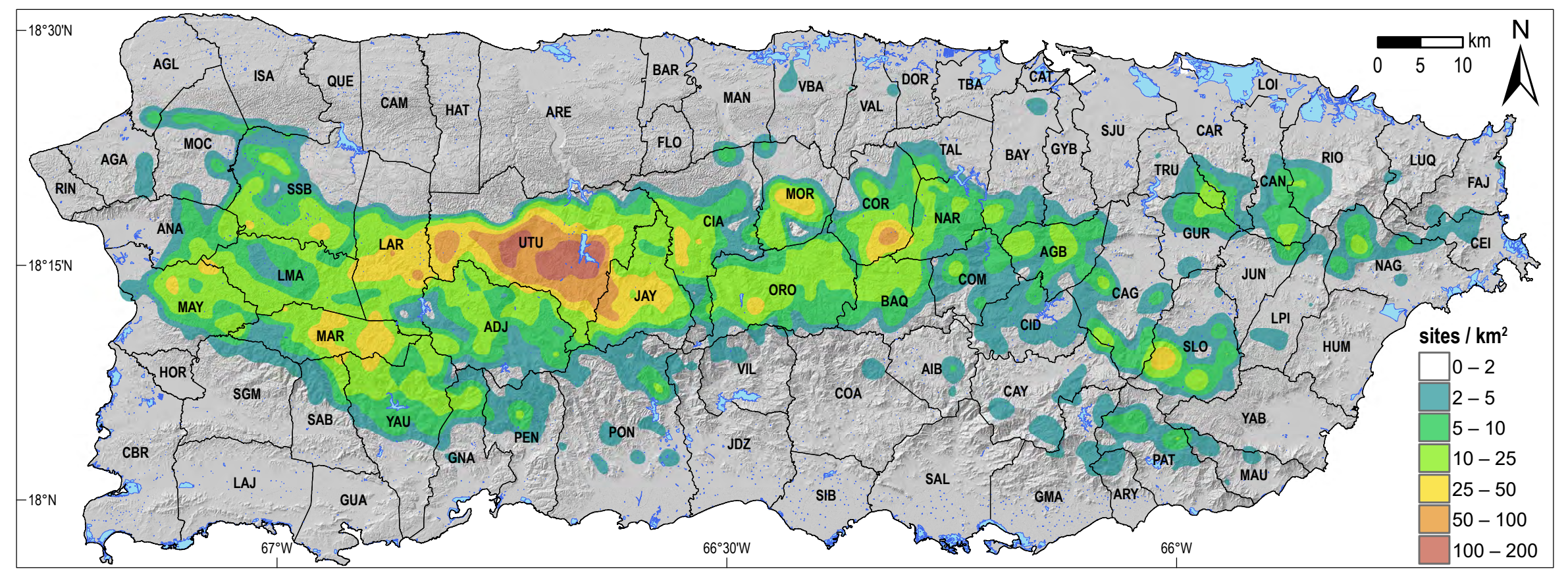

Figure 13. Density of landslide sites from the Hurricane María event inventory. Point data from Hughes and others (2019) were used to determine the spatial density of the points, which is shown in the figure. The figure was created with kernel density technique using a 2-km-diameter window. Explanation of municipality abbreviations can be found in appendix 1. (km, kilometer; $\mathrm{km}^{2}$, square kilometer) 
Table 1. Hypothetical examples of a set of frequency-ratio (FR) values and corresponding Susceptibility Index $(S /)$ values for a given bin ( $i)$ of any characteristic $(f)$. Cooler colors represent increasingly less correlation between the characteristic bin and inventory sites. Warmer colors represent increasingly greater correlation between the characteristic bin and inventory sites. A FR value of 1 and $S /$ value of 0 are neutral. $S I$ is the natural $\log$ of $F R$.

$\left[F R_{f}\right.$, the frequency-ratio value for each bin $(i)$ of each characteristic $(f) ; S I_{f}$, the $S I$ value for each bin $(i)$ of each characteristic $(f)]$

\begin{tabular}{lll}
\hline Ratio & $F R_{f i}$ & $S I_{f i}$ \\
$1: 5$ & 0.2 & -1.61 \\
$1: 4$ & 0.25 & -1.39 \\
$1: 3$ & 0.33 & -1.11 \\
$1: 2$ & 0.5 & -0.69 \\
$1: 1$ & 1 & 0 \\
$2: 1$ & 2 & 0.69 \\
$3: 1$ & 3 & 1.1 \\
$4: 1$ & 4 & 1.39 \\
$5: 1$ & 5 & 1.61 \\
\hline
\end{tabular}

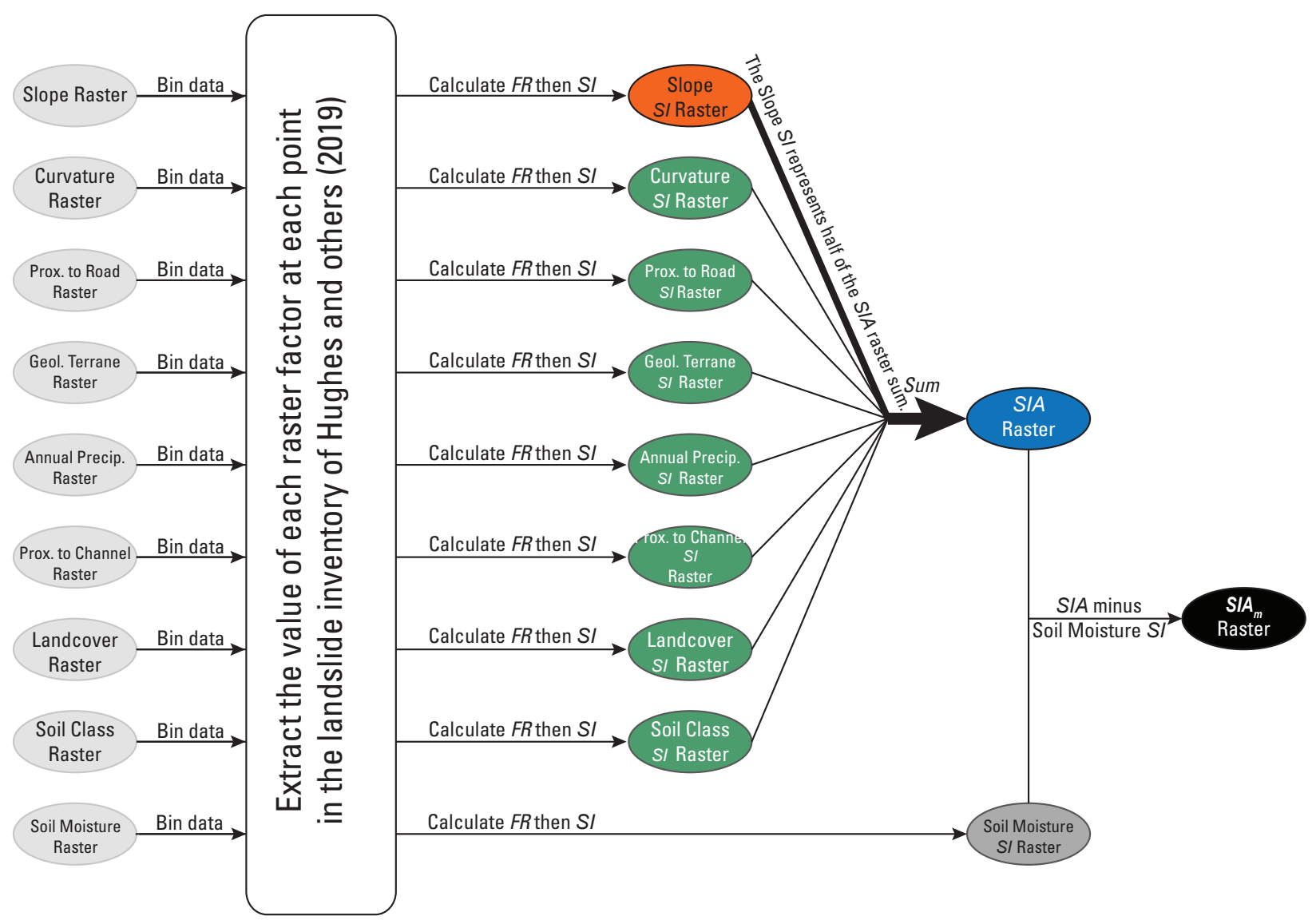

Figure 14. Flowchart depicting the process followed to develop the $S I A_{m}$ raster, which forms the basis for the landslide susceptibility map (geol., geological; precip., precipitation; prox., proximity; FR, frequency ratio; SI, Susceptibility Index; $S I A$, aggregate Susceptibility Index; $S I A_{m^{\prime}}$ aggregate Susceptibility Index modified by soil moisture) 
Table 2. Data utilized in the frequency-ratio analyses.

[USGS, U.S. Geological Survey: lidar, light detection and ranging; NHD, National Hydrography Dataset; GAP, Puerto Rico Gap Analysis Program; USDA, U.S. Department of Agriculture; NRCS, Natural Resources Conservation Service; NASA, National Aeronautics and Space Administration]

\begin{tabular}{|c|c|c|c|c|}
\hline Factor $^{1}$ & Data source & Original resolution & Final resolution & Interpolation \\
\hline Slope & 2015-2016 USGS lidar² & 1 meter & 5 meters & No \\
\hline Curvature & 2015-2016 USGS lidar² & 1 meter & 5 meters & No \\
\hline Geology & $\begin{array}{l}\text { USGS/Puerto Rico Office of Management \& } \\
\text { Budget }^{4}\end{array}$ & $1: 20,000$ polygon vector & 5 meters & No \\
\hline Land cover & USDA GAP Land Cover ${ }^{6}$ & 15 meters & 5 meters & No \\
\hline Soil classification & $\mathrm{USDA}_{\mathrm{NRCS}}{ }^{7}$ & Polygon vector & 5 meters & No \\
\hline Soil moisture & NASA Soil Moisture Active Passive ${ }^{8}$ & 9,008 meters & 5 meters & Yes \\
\hline
\end{tabular}

${ }^{1}$ Factors are highlighted in bolded text when first described in the following paragraphs. ${ }^{2}$ USGS, 2017.

${ }^{3}$ U.S. Census Bureau, 2015.

${ }^{4}$ Puerto Rico Oficina de Gerencia y Presupuesto, 2018.

${ }^{5}$ USGS, 2019.

${ }^{6}$ Gould and others, 2008.

${ }^{7}$ USDA, 2018.

${ }^{8}$ NASA, 2017. 
The factors used in the analysis are recorded in table 2. The resultant output model has the slope $S I$ values as half of the input and all other combined factors as the remaining half of the input. This weighting of slope input was selected by trial-anderror evaluations of effects on regions known to have historically high and low landslide susceptibility.

In order to make the susceptibility map applicable for any intense rainfall event, an attempt was made to temper any bias resulting from variable rainfall and soil moisture conditions unique to the Hurricane María event because the model was derived from that single rainfall event inventory. Bessette-Kirton and others (2019) found that the spatial density of landslides triggered by Hurricane María correlated well with remotely sensed root zone soil moisture data from the National Aeronautics and Space Administration (NASA) Soil Moisture Active Passive (SMAP) mission collected 1 day after the event (NASA, 2017), and did not correlate as well with rainfall estimates. Using equation 4, we calculated SI values for the same SMAP data and subtracted these from the SIA values to account for soil moisture variability following the hurricane:

$$
S I A_{m}=S I A-S I_{S M A P}
$$

where:

$S I A_{m} \quad$ is the final modified $S I$ value at each 5-m pixel islandwide, and

$S I_{S M A P} \quad$ is the $S I$ value calculated based on the root zone soil moisture content estimated for 21 September 2017.

The SMAP dataset is discussed further below, as is an approach to utilize future SMAP data along with the landslide susceptibility map data to improve forecasts of the locations of landslides triggered by specific events (in the "Use and Limitations of the Landslide Susceptibility Map" section.)

Slope angle is usually considered one of the most important factors with regards to mass wasting, especially for shallow failures (for example, Carson and Petley, 1970). Values of slope at $5-\mathrm{m}$ pixel resolution were binned into $5^{\circ}$ intervals for analysis. All slopes greater than $45^{\circ}$ were combined into one group. The distribution of slope bins across the island is presented in table 3 and figure 15 . About 40 percent of the island has a slope of less than $10^{\circ}$, another 40 percent has a slope between $10-30^{\circ}$, and the remaining 20 percent is greater than $30^{\circ}$ inclination. The lowest slopes are generally coastal; however, broad alluvial valleys are present in some interior zones along rivers such as the Rio Gurabo, Rio Grande de Arecibo, and others. The north coast karst province is a zone of especially high slopes along the flanks of mogotes, sinkholes, zanjones, and other dissolution features.

Where the karst is covered by blanket sand deposits, the north coast has very low slopes. Along the Cordillera Central, slopes on the southern flank are generally higher, on average, given that the rivers destined for the Caribbean Sea have shorter distances to descend to base level from the divide. Notable high-slope topographic features across the island include the Lares escarpment along the southern edge of the karst province, river gorges incised into the karst terrain (Rio Guajataca, Rio Camuy, Rio Tanamá, Rio Grande de Arecibo, Rio Grande de Manatí), and the Cañon San Cristobal. Not all high slope zones are confined to the higher elevation interior as there are prominent sea cliffs in both northwestern and southeastern corners of the island, in addition to other locations. Although most urban centers are positioned in lower slope areas, the population density across the rugged interior remains high. Lakes and reservoirs were classified as areas with $0^{\circ}$ slope.

Hillslope curvature is classified as convex, concave, or planar. Ridge tops are generally convex but hollows are concave. Curvature was calculated at $5-\mathrm{m}$ pixel resolution using the combination of profile and planform profiles (standard curvature function). Positive values represent convexities and negative values represent concavities. The amount of convex versus concave topography across Puerto Rico is approximately equal (about 35 percent each) and pixels classified as planar and near-planar represent the remaining approximately 30 percent (fig. 16). Curvature values are binned as shown in table 3 . Lakes and reservoirs are classified as planar areas.

Both slope and curvature metrics are calculated from a pre-María 1-m resolution lidar-derived DEM raster (USGS, 2017) that was resampled to 5-m resolution. Using lidar data has been shown to be far superior for landslide investigations than traditional, low-resolution DEMs created with photogrammetric methods (for example, Schulz, 2007). The lidar-derived DEM is almost complete for the island. Data do not exist for approximately $55 \mathrm{~km}^{2}$ (less than 1 percent of the island) located in the vicinity of Lago Carite in southeastern Puerto Rico (fig. 17). The three polygonal zones without data are mostly in Cayey and Guayama municipalities with much less expression in Salinas, Patillas, San Lorenzo, and Yabucoa municipalities. Within these zones, the gaps were seamlessly filled with older, non-lidar data extracted from a 5-m resolution DEM (Puerto Rico Centro de Recaudación de Ingresos Municipales, 1998). The DEM used to fill the data gaps results in a less-detailed slope and curvature product in those specific areas because the DEM was produced using aerial imagery photogrammetry, which reveals less ground surface detail than a lidar survey.

Roadway construction often involves cutting and filling of the natural landscape. If Puerto Rico were an independent nation, its road density (kilometer/square kilometer) would rank ninth globally (NationMaster, 2017). Larsen and Parks (1997) showed that proximity to road surfaces in mountainous regions of Puerto Rico increases the likelihood of mass wasting. This correlation is a result of stress redistribution from cutting and filling, and alteration of surface and subsurface drainage paths, all of which can result in decreased slope stability. In addition, many rural roads are not constructed using best practices for reducing slope instability (Larsen and Parks, 1997). The correlation between landslides and the presence of roads was explored using the Hurricane María 


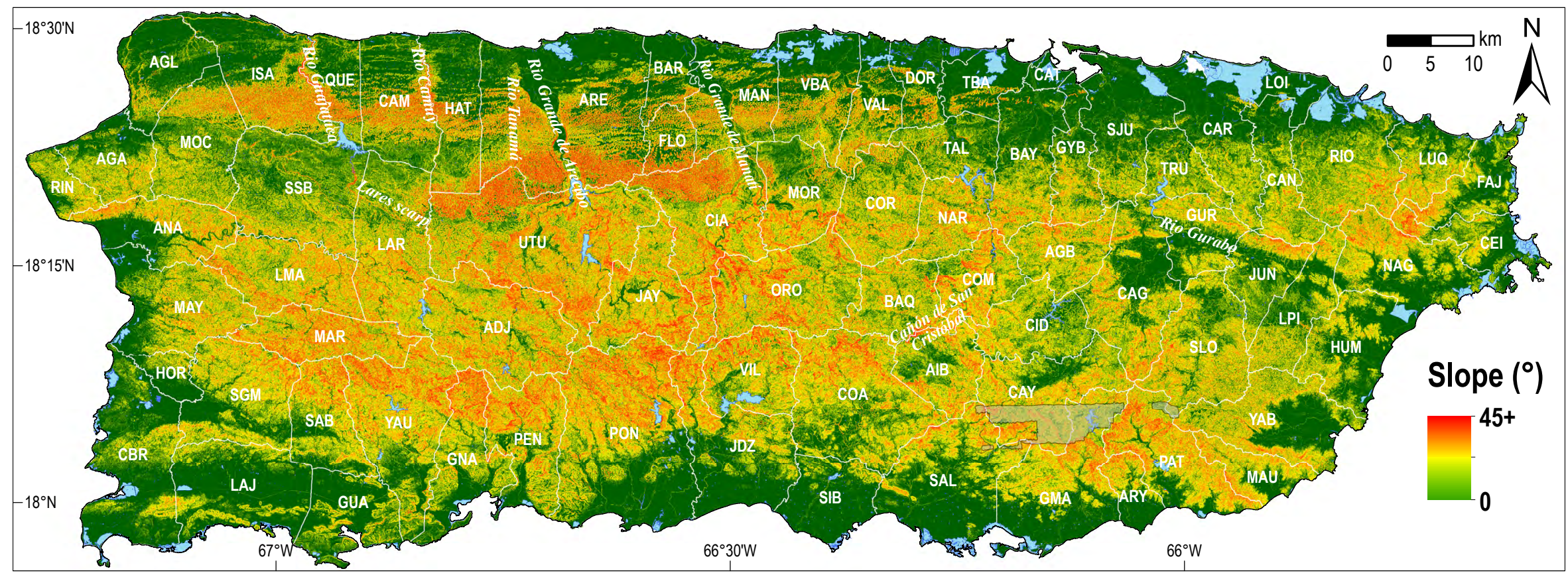

Figure 15. Slope map for the island of Puerto Rico. Values calculated from lidar-derived digital elevation model (U.S. Geological Survey, 2017). Resolution is 5 meters. The shaded polygonal zones mostly within Cayey (CAY) and Guayama (GMA) in the southeast are explained in the text and shown on figure 17. Explanation of municipality abbreviations can be found in appendix $1 .\left(\mathrm{km}\right.$, kilometer; ${ }^{\circ}$, degree] 


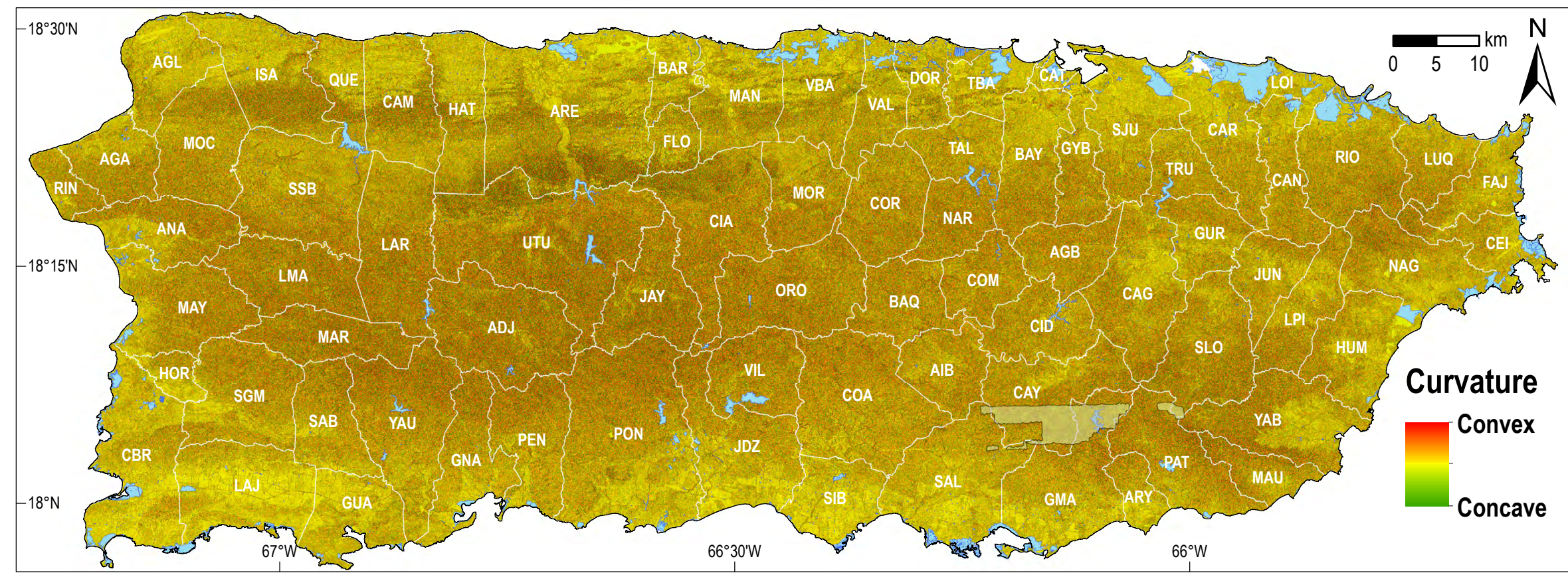

Figure 16. Curvature values calculated from lidar-derived digital elevation model for the island of Puerto Rico (U.S. Geological Survey, 2017). Resolution is 5 meters. The shaded polygonal zones mostly within Cayey (CAY) and Guayama (GMA) in the southeast are explained in the text and shown on figure 17. Explanation of municipality abbreviations can be found in appendix 1. (km, kilometer) 
Table 3. Results from frequency-ratio analyses of potential landslide-contributing factors.

[Values may not sum due to rounding. ${ }^{\circ}$, degree; $\mathrm{km}^{2}$, square kilometer; \%, percent; \#, number; FR, frequency ratio; SI, Susceptibility Index; —, not applicable; m, meter; <, less than; >, greater than; K-T, Cretaceous and Tertiary; wv/sv, water volume/soil volume]

\begin{tabular}{|c|c|c|c|c|c|c|}
\hline Bin & Area $\left(\mathbf{k m}^{2}\right)$ & Area (\%) & Landslides' (\#) & Landslides ${ }^{1}(\%)$ & FR & $S I$ \\
\hline \multicolumn{7}{|c|}{ Slope } \\
\hline $0-5^{\circ}$ & $2,477.5$ & 28.5 & 415 & 0.8 & 0.03 & -3.60 \\
\hline $10-15^{\circ}$ & 821.8 & 9.4 & 1,114 & 2.1 & 0.22 & -1.51 \\
\hline $15-20^{\circ}$ & 867.6 & 10.0 & 2,157 & 4.0 & 0.40 & -0.91 \\
\hline $30-35^{\circ}$ & 773.5 & 8.9 & 12,403 & 23.2 & 2.61 & 0.96 \\
\hline $35-40^{\circ}$ & 545.4 & 6.3 & 13,316 & 24.9 & 3.97 & 1.38 \\
\hline $40-45^{\circ}$ & 282.1 & 3.2 & 8,468 & 15.8 & 4.88 & 1.59 \\
\hline $45-90^{\circ}$ & 181.9 & 2.1 & 3,198 & 6.0 & 2.86 & 1.05 \\
\hline$-50--25(0.01 / \mathrm{m})$ & 66.4 & 0.8 & 882 & 1.60 & 2.16 & 0.77 \\
\hline$-25--10(0.01 / \mathrm{m})$ & 446.9 & 5.1 & 6,551 & 12.20 & 2.38 & 0.87 \\
\hline$-10--5(0.01 / \mathrm{m})$ & 681.4 & 7.8 & 7,285 & 13.60 & 1.74 & 0.55 \\
\hline$-5--1(0.01 / \mathrm{m})$ & $1,845.2$ & 21.2 & 8,293 & 15.50 & 0.73 & -0.31 \\
\hline$-1-1(0.01 / \mathrm{m})$ & $2,489.4$ & 28.6 & 4,739 & 8.80 & 0.31 & -1.17 \\
\hline $1-5(0.01 / \mathrm{m})$ & $1,876.8$ & 21.6 & 8,029 & 15.00 & 0.70 & -0.36 \\
\hline $5-10(0.01 / \mathrm{m})$ & 785.5 & 9.0 & 7,453 & 13.90 & 1.54 & 0.43 \\
\hline $10-25(0.01 / \mathrm{m})$ & 462.8 & 5.3 & 9,166 & 17.10 & 3.22 & 1.17 \\
\hline $25-50(0.01 / \mathrm{m})$ & 38.9 & 0.4 & 1,114 & 2.10 & 4.66 & 1.54 \\
\hline \multicolumn{7}{|c|}{ Proximity to road surface } \\
\hline $25-50 \mathrm{~m}$ & $1,363.1$ & 15.6 & 9,809 & 18.30 & 1.17 & 0.16 \\
\hline $50-75 \mathrm{~m}$ & $1,012.9$ & 11.6 & 6,968 & 13.00 & 1.12 & 0.11 \\
\hline $75-100 \mathrm{~m}$ & 782.1 & 9.0 & 5,049 & 9.40 & 1.05 & 0.05 \\
\hline $100-200 \mathrm{~m}$ & $1,798.0$ & 20.6 & 10,319 & 19.30 & 0.93 & -0.07 \\
\hline $200-400 \mathrm{~m}$ & $1,119.3$ & 12.8 & 4,471 & 8.40 & 0.65 & -0.43 \\
\hline $400-1,000 \mathrm{~m}$ & 397.2 & 4.6 & 772 & 1.40 & 0.32 & -1.15 \\
\hline $1,000+\mathrm{m}$ & 52.4 & 0.6 & 27 & 0.05 & 0.08 & -2.48 \\
\hline Total & $8,717.3$ & 100.0 & $\mathbf{5 3 , 5 7 3}$ & 99.95 & - & - \\
\hline \multicolumn{7}{|c|}{ Geologic terrane } \\
\hline Quaternary alluvium & $1,875.1$ & 21.5 & 438 & 0.80 & 0.040 & -3.27 \\
\hline Tertiary cover sequence & $1,496.9$ & 17.2 & 1,102 & 2.10 & 0.120 & -2.12 \\
\hline Cretaceous non-igneous & 61.1 & 0.7 & 9 & 0.02 & 0.020 & -3.73 \\
\hline Tertiary intrusive & 285.5 & 3.3 & 2,829 & 5.30 & 1.610 & 0.48 \\
\hline Cretaceous intrusive & 654.2 & 7.5 & 15,149 & 28.30 & 3.760 & 1.33 \\
\hline
\end{tabular}


Table 3. Results from frequency-ratio analyses of potential landslide-contributing factors.-Continued

[Values may not sum due to rounding. ${ }^{\circ}$, degree; $\mathrm{km}^{2}$, square kilometer; \%, percent; \#, number; FR, frequency ratio; SI, Susceptibility Index; -, not applicable; m, meter; $<$, less than; >, greater than; K-T, Cretaceous and Tertiary; wv/sv, water volume/soil volume]

\begin{tabular}{|c|c|c|c|c|c|c|}
\hline Bin & Area $\left(\mathrm{km}^{2}\right)$ & Area (\%) & Landslides'1 (\#) & Landslides $^{1}(\%)$ & FR & SI \\
\hline $\mathrm{K}-\mathrm{T}$ volcaniclastic & $3,506.5$ & 40.3 & 31,514 & 58.80 & 1.460 & 0.38 \\
\hline Hydrothermic/metamorphic & 112.0 & 1.3 & 588 & 1.10 & 0.850 & -0.16 \\
\hline Serpentinite/amphibolite & 115.1 & 1.3 & 408 & 0.80 & 0.580 & -0.55 \\
\hline Quaternary landslide & 53.2 & 0.6 & 232 & 0.40 & 0.710 & -0.34 \\
\hline \multicolumn{7}{|c|}{ Mean annual precipitation } \\
\hline $0-250 \mathrm{~mm}$ & 0.0 & 0.0 & 0 & 0.000 & - & - \\
\hline $250-500 \mathrm{~mm}$ & 0.0 & 0.0 & 0 & 0.000 & - & - \\
\hline $500-750 \mathrm{~mm}$ & 0.0 & 0.0 & 0 & 0.000 & - & - \\
\hline $1,500-1,750 \mathrm{~mm}$ & $1,859.8$ & 21.3 & 3,190 & 6.000 & 0.28 & -1.28 \\
\hline $1,750-2,000 \mathrm{~mm}$ & $3,149.4$ & 36.1 & 20,498 & 38.700 & 1.06 & 0.06 \\
\hline $2,000-2,250 \mathrm{~mm}$ & $1,637.9$ & 18.8 & 23,469 & 43.800 & 2.33 & 0.85 \\
\hline $2,250-2,500 \mathrm{~mm}$ & 290.8 & 3.3 & 6,169 & 11.500 & 3.45 & 1.24 \\
\hline Total & $8,716.9$ & 100.0 & 53,573 & 100.502 & - & - \\
\hline \multicolumn{7}{|c|}{ Proximity to fluvial channel } \\
\hline $0-10 \mathrm{~m}$ & 309.9 & 3.6 & 780 & 1.5 & 0.41 & -0.89 \\
\hline $10-25 \mathrm{~m}$ & 388.2 & 4.5 & 2,091 & 3.9 & 0.88 & -0.13 \\
\hline $25-50 \mathrm{~m}$ & 602.6 & 6.9 & 4,941 & 9.2 & 1.33 & 0.29 \\
\hline $1,000+\mathrm{m}$ & 605.4 & 7.0 & 89 & 0.2 & 0.02 & -3.73 \\
\hline Total & $8,716.1$ & 100.0 & 53,573 & 100.0 & - & 一 \\
\hline \multicolumn{7}{|c|}{ Land cover ${ }^{3}$} \\
\hline Moist grasslands and pastures & $2,184.6$ & 25.10 & 14,547 & 27.20 & 1.08 & 0.08 \\
\hline $\begin{array}{l}\text { Montane wet evergreen abandoned/active } \\
\text { coffee plantation }\end{array}$ & 548.9 & 6.30 & 13,920 & 26.00 & 4.12 & 1.42 \\
\hline $\begin{array}{l}\text { Young secondary lowland moist noncal- } \\
\text { careous evergreen forest }\end{array}$ & 530.5 & 6.10 & 3,077 & 5.70 & 0.94 & -0.06 \\
\hline High density urban development & 522.8 & 6.00 & 38 & 0.10 & 0.01 & -4.44 \\
\hline $\begin{array}{l}\text { Mature secondary moist limestone ever- } \\
\text { green and semideciduous forest }\end{array}$ & 464.6 & 5.30 & 130 & 0.20 & 0.05 & -3.09 \\
\hline $\begin{array}{l}\text { Montane wet noncalcareous evergreen } \\
\text { shrubland and woodland }\end{array}$ & 241.1 & 2.80 & 5,831 & 10.90 & 3.93 & 1.37 \\
\hline $\begin{array}{l}\text { Young secondary montane wet noncal- } \\
\text { careous evergreen forest }\end{array}$ & 216.7 & 2.50 & 4,018 & 7.50 & 3.02 & 1.10 \\
\hline
\end{tabular}


Table 3. Results from frequency-ratio analyses of potential landslide-contributing factors.-Continued

[Values may not sum due to rounding. ${ }^{\circ}$, degree; $\mathrm{km}^{2}$, square kilometer; \%, percent; \#, number; FR, frequency ratio; SI, Susceptibility Index; —, not applicable; m, meter; <, less than; >, greater than; K-T, Cretaceous and Tertiary; wv/sv, water volume/soil volume]

\begin{tabular}{|c|c|c|c|c|c|c|}
\hline Bin & Area $\left(\mathrm{km}^{2}\right)$ & Area $(\%)$ & Landslides $^{1}$ (\#) & Landslides $^{1}(\%)$ & FR & SI \\
\hline $\begin{array}{l}\text { Montane west alluvial shrubland and } \\
\text { woodland }\end{array}$ & 9.0 & 0.10 & 120 & 0.20 & 2.17 & 0.77 \\
\hline Wet serpentine shrubland and woodland & 3.6 & 0.04 & 42 & 0.08 & 1.91 & 0.64 \\
\hline Total & $8,713.5$ & 100.00 & 53,573 & 100.00 & - & - \\
\hline $\begin{array}{l}\text { Mucara clay } \\
(326695) 40-60 \% \text { slopes }\end{array}$ & 298.9 & 3.40 & 2,154 & 4.0 & 1.17 & 0.16 \\
\hline $\begin{array}{l}\text { Tanamá Rock Outcrop } \\
\text { (326474) 12-60\% slopes }\end{array}$ & 239.4 & 2.80 & 46 & 0.1 & 0.03 & -3.47 \\
\hline $\begin{array}{l}\text { Caguabo clay loam } \\
\text { (326645) } 40-60 \% \text { slopes }\end{array}$ & 218.5 & 2.50 & 877 & 1.6 & 0.65 & -0.43 \\
\hline $\begin{array}{l}\text { Caguabo clay loam } \\
\text { (326863) } 20-60 \% \text { slopes }\end{array}$ & 128.6 & 1.50 & 297 & 0.6 & 0.38 & -0.98 \\
\hline $\begin{array}{l}\text { Pellejas clay loam } \\
\text { (326463) } 40-60 \% \text { slopes }\end{array}$ & 98.9 & 1.10 & 8,524 & 15.9 & 14.01 & 2.64 \\
\hline $\begin{array}{l}\text { Maricao clay } \\
\text { (326577) } 20-60 \% \text { slopes }\end{array}$ & 3.8 & 0.04 & 295 & 0.6 & 12.65 & 2.54 \\
\hline $\begin{array}{l}\text { Lirios clay loam } \\
\text { (326445) } 40-60 \% \text { slopes }\end{array}$ & 59.1 & 0.70 & 3,802 & 7.1 & 10.47 & 2.35 \\
\hline $\begin{array}{l}\text { Los Guineous clay } \\
\text { (326566) 20-60\% slopes }\end{array}$ & 6.9 & 0.08 & 374 & 0.7 & 8.78 & 2.17 \\
\hline $0.20-0.25 \mathrm{wv} / \mathrm{sv}$ & 260.4 & 2.99 & 576 & 1.08 & 0.36 & -1.02 \\
\hline $0.25-0.30 \mathrm{wv} / \mathrm{sv}$ & $1,081.4$ & 12.41 & 988 & 1.84 & 0.15 & -1.91 \\
\hline $0.30-0.35 \mathrm{wv} / \mathrm{sv}$ & $2,118.2$ & 24.30 & 2,852 & 5.32 & 0.22 & -1.52 \\
\hline $0.35-0.40 \mathrm{wv} / \mathrm{sv}$ & $3,150.9$ & 36.15 & 19,051 & 35.56 & 0.98 & -0.02 \\
\hline $0.40-0.45 \mathrm{wv} / \mathrm{sv}$ & $1,571.6$ & 18.03 & 22,477 & 41.96 & 2.33 & 0.84 \\
\hline $0.45-0.50 \mathrm{wv} / \mathrm{sv}$ & 208.7 & 2.39 & 6,829 & 12.75 & 5.33 & 1.67 \\
\hline Total & $8,716.7$ & 100.00 & 53,573 & 100.00 & - & - \\
\hline
\end{tabular}

${ }^{1}$ Only a random 75 percent of the Hurricane María slope failure inventory was used to calculate the FR and SI values. The remaining 25 percent was used to test the final model. The total number of sites in the inventory is 71,431 .

${ }^{2}$ The minimum $S I$ value used in the model creation was -5.00 . SI values less than this limit were set to -5.00 . This was employed in order to avoid incorporating anomalously low SI values in the model due to low factor areal extent.

${ }^{3}$ The Puerto Rico Gap Analysis Program dataset includes 66 distinct land cover classifications across Puerto Rico. Only the top five most widespread and top five FR value classes are shown here. The full data and results are in appendix 2 and Hughes and Schulz (2020).

${ }^{4}$ The U.S. Department of Agriculture Natural Resources Conservation Service soils dataset includes 697 unique soil unit numerical key code (mapunit key [MUKEY]) classes for the island of Puerto Rico. Only the top five most widespread and top five FR value classes are shown here. The full data and results are in appendix 3 and Hughes and Schulz (2020). The number in parenthesis listed for each soil class is the corresponding MUKEY. 
event inventory and the U.S. Census Bureau TIGER line shapefile (fig. 18; U.S. Census Bureau, 2015). A raster populated with Euclidean distances to road surfaces was created at 5-m resolution. The results of this exercise, summarized in table 3, reveal that more than 50 percent of the island lies within $75 \mathrm{~m}$ of a roadway and only about 5 percent of the island lies more than $400 \mathrm{~m}$ from a road surface. The study by Larsen and Parks (1997) showed that mountainous terrain within $85 \mathrm{~m}$ of a roadway is at least 5 times more likely to suffer landsliding. Importantly, the TIGER line shapefile does not include many of the improvised and densely constructed farm and hacienda roads (fig. 19). In the early 20th century, Dorsey and others (1903) described the interior of the island to have "many trails which penetrate the island in almost every direction" (p. 839). These trails, paths, and roads have been shown to be primary sources of erosion and sedimentation within the Cordillera Central (Ramos-Scharrón and LaFevor, 2016).

Bedrock composition is very diverse across Puerto Rico (Jolly and others, 1998b). The rock type combined with the varying effects of tropical chemical weathering result in distinct regolith products with varying susceptibility to mass movement. A digitized compilation of geologic quadrangle maps at 1:20,000 scale prepared by the USGS in the latter half of the 20th century was utilized in this study (Puerto Rico Oficina de Gerencia y Presupuesto, 2018). For the quadrangles that were not published at 1:20,000 scale (Rincón, Guánica, and Sabana Grande), both unpublished 1:20,000 scale maps and published 1:100,000 map data were used for the digitization. The hundreds of geological units were binned according to the 10 terranes assigned by Bawiec (1998). The 10 terranes, as well as surficial water, are shown on figure 20. The data in table 3 show that about 20 percent of the island is classified as Quaternary alluvium. An almost equal area is underlain by the Tertiary cover sequence rocks. About 40 percent of the island is the volcaniclastic basement complex with an additional almost 10 percent of Cretaceous and Tertiary intrusive igneous rocks. The less than 1 percent of the island mapped as Quaternary landslides includes mostly deep bedrock features mapped along the southern margin of the karst province by Watson Monroe and associates (Monroe, 1963, 1967, 1969a, 1969b; Berryhill, 1965; Briggs, 1965, 1968; Nelson, 1967; Nelson and Tobisch, 1968; Pease, 1968; McIntyre, 1971; Tobisch and Turner, 1971). The digitized 1:20,000 polygon shapefile was rasterized and reclassified to terrane at a 5-m resolution.

Although measuring only $170 \mathrm{~km}$ x $60 \mathrm{~km}$, the main island of the Puerto Rican archipelago is home to several microclimates. Topographic features across the island, namely the Sierra de Luquillo and the Cordillera Central, coupled with the prevailing trade winds create both orographic rainfall and rain shadows. The prominent El Yunque rainforest in the eastern region and the central western interior are the wettest zones with more than $2 \mathrm{~m}$ of annual rainfall; the Guánica dry forest and other zones of the arid south coast receive less than $1 \mathrm{~m}$ of precipitation yearly (fig. 21; Fick and Hijmans, 2017). Areas with higher annual precipitation are more likely to be subjected to more intense chemical weathering in the humid tropical climate. The effect of chemical weathering is important in bedrock decomposition and soil development, both of which can influence hillslope stability. Additionally, because of orographic effects that result in higher precipitation at higher elevation, precipitation generally may partially serve as a proxy to represent mountainous areas, which are more likely to host landslides. Analysis of the precipitation dataset shows about 6 percent of the island with less than $1 \mathrm{~m}$ of annual rainfall, approximately 70 percent of the island between $1 \mathrm{~m}$ and $2 \mathrm{~m}$ of annual precipitation, and just over 20 percent with greater than $2 \mathrm{~m}$ of yearly rainfall (table 3 ). For the FR calculations, the dataset was binned into 0.25 - $\mathrm{m}$ intervals. The original resolution of the dataset is $900 \mathrm{~m}$, but it was resampled-not interpolated or smoothed - to 5-m pixel size to be consistent with the other factor raster datasets.

The principal agent of erosion in Puerto Rico is landsliding (Larsen, 2012), much of which occurs as a topographic adjustment to fluvial incision. Locally forced by tectonic uplift, fluvial downcutting results in oversteepened hillslopes that are primed for failure. Much like the distance to the road surface is used as an input to the model, proximity to fluvial channel is also incorporated. This factor addresses drainage network density, and distinguishes between the "normal" topographic terrain where surficial drainage dominates and the large karst province in the northern region of Puerto Rico, where there are very limited surficial drainage expressions in the landscape. The dataset used for the fluvial channels is the USGS National Hydrography Dataset flowline shapefile archive (fig. 22; USGS, 2019). Similar to the TIGER line shapefile for roads, Euclidean distance to the flowline shapefile features was generated at $5-\mathrm{m}$ pixel resolution. The resultant raster dataset reveals that just under 30 percent of the island lies within $100 \mathrm{~m}$ of a fluvial channel as defined by the USGS, 50 percent of the island is between $100 \mathrm{~m}$ and $400 \mathrm{~m}$ from a fluvial channel, about 15 percent lies between $400 \mathrm{~m}$ and $1,000 \mathrm{~m}$ of a fluvial channel, and 7 percent of the island is more than $1,000 \mathrm{~m}$ from a fluvial channel (table 3). The areas of the island that lie farthest from fluvial channels are mostly in the northern karst zone, where many flow paths are subterranean. The bins for this dataset are set at the same intervals as the proximity-to-roads analysis.

The 20th century in Puerto Rico was a time of extended transition from a primarily agrarian civilization after 400 years of Spanish rule to a more modern, urbanized society (Dietz, 1986). The natural environment had been intensively modified by anthropomorphic activity prior to the island's acquisition by the United States. More recently, vast swaths of cultivated land have been abandoned and left to nature, resulting in reforestation across the island (Grau and others, 2003). Land cover is also integrated into the FR analysis because it reflects the type of local terrain and land-use styles that can control the topographic response to environmental forcings (Philpott and others, 2008). The Puerto Rico Gap Analysis Program (GAP) land cover raster (Gould and others, 2008) was chosen for the study and is resampled - not interpolated-from 15-m resolution to 5-m resolution in order to be compatible with the other model input datasets. The GAP data raster includes 66 distinct classifications (fig. 23), which were used during the analysis without combining the different classifications. The GAP data (table 3; app. 2; Hughes and 


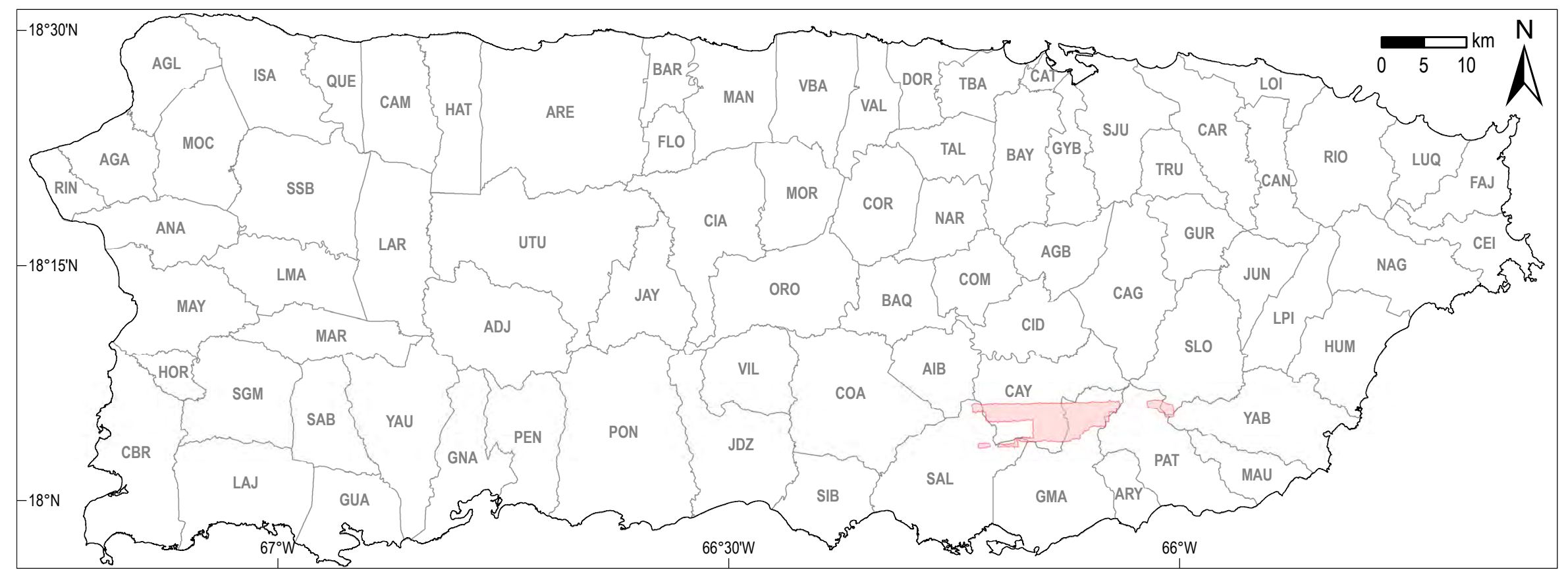

Figure 17. Missing zones for the 2015-2016 airborne lidar survey of Puerto Rico (U.S. Geological Survey, 2017) are shown as red polygons in the southeastern quadrant of the island. The gaps in coverage occur in portions of the municipalities of Salinas (SAL), Cayey (CAY), Guayama (GMA), Patillas (PAT), San Lorenzo (SLO), and Yabucoa (YAB). The data holes were patched with a preexisting 5-meter digital elevation model generated by the Puerto Rico Centro de Recaudación de Ingresos Municipales (1998). Explanation of municipality abbreviations can be found in appendix 1. (km, kilometer) 


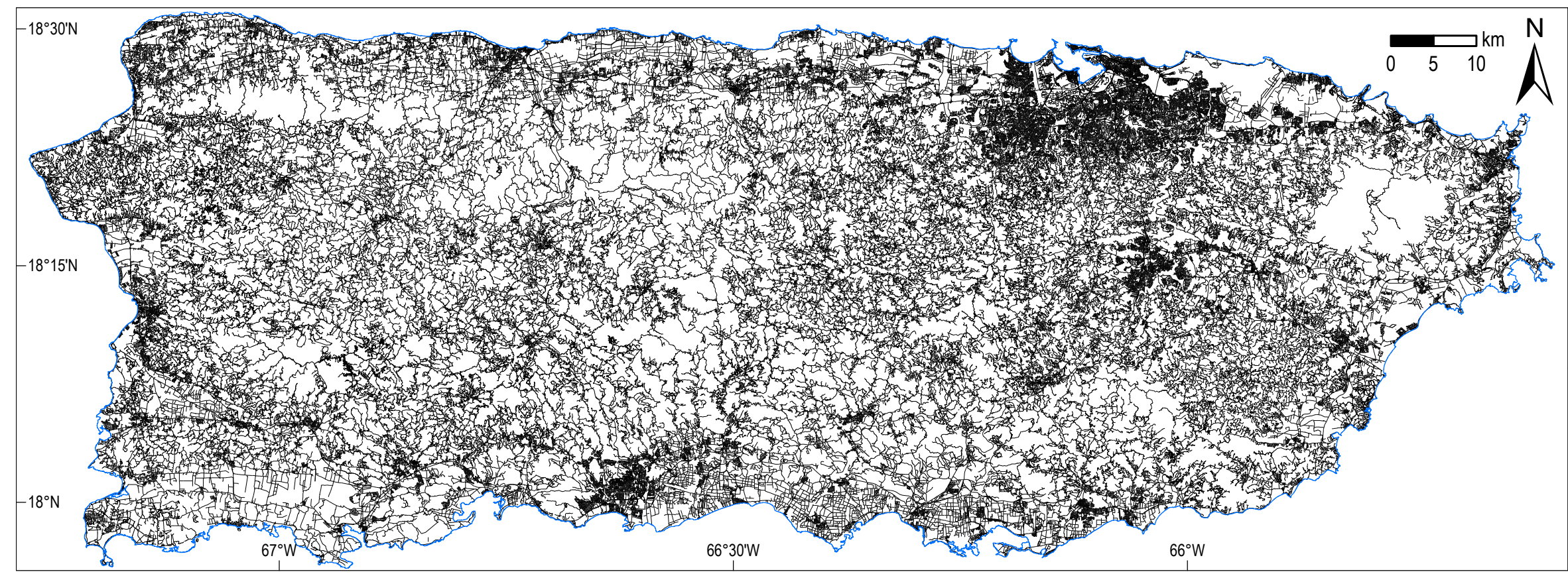

Figure 18. Paved roads on the island of Puerto Rico (U.S. Census Bureau, 2015). The densest population centers of San Juan (metro area), Caguas, and Ponce are distinct. Zones with very few roads are in the northwestern karst interior and in the Sierra de Luquillo (fig. 1) in the northeast of the island. The U.S. Census Bureau TIGER shapefile roads do not include dense farm road networks (see fig. 19). (km, kilometer) 

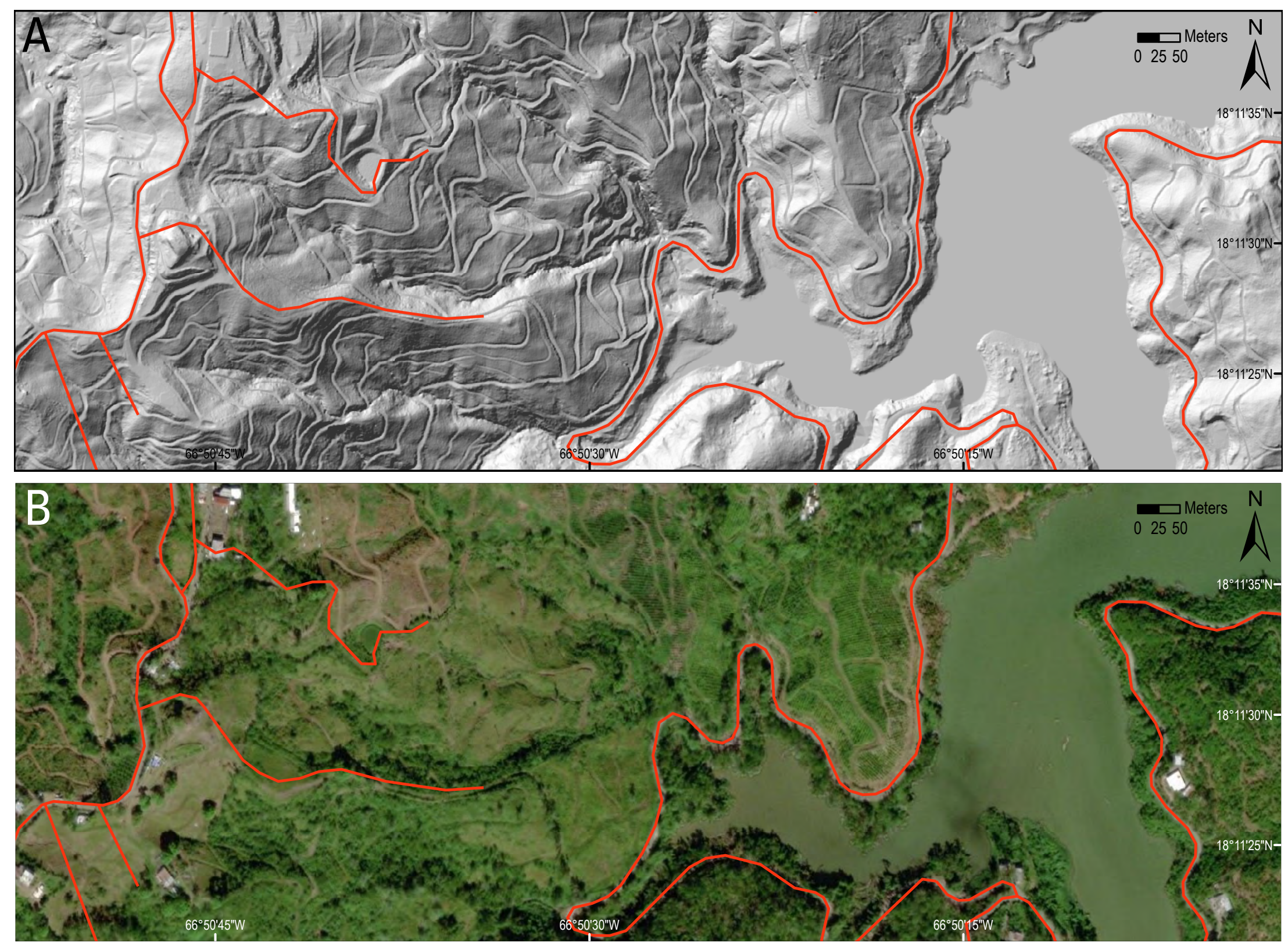

Figure 19. Example of dense improvised farm road network that is not digitized as part of the U.S. Census Bureau (2015) TIGER roads shapefile (shapefile roads shown as red lines). A, Hillshade raster from lidar-derived digital elevation model (U.S. Geological Survey, 2017) reveals very dense unpaved paths and trails that have been built across much of the mountainous interior of Puerto Rico and B, Aerial photograph of the same area. Location $(18.190,-66.840)$ is Hacienda Buena Vista near Castañer at the upper end of Lago Guayo in the municipality of Lares. (m, meter) 


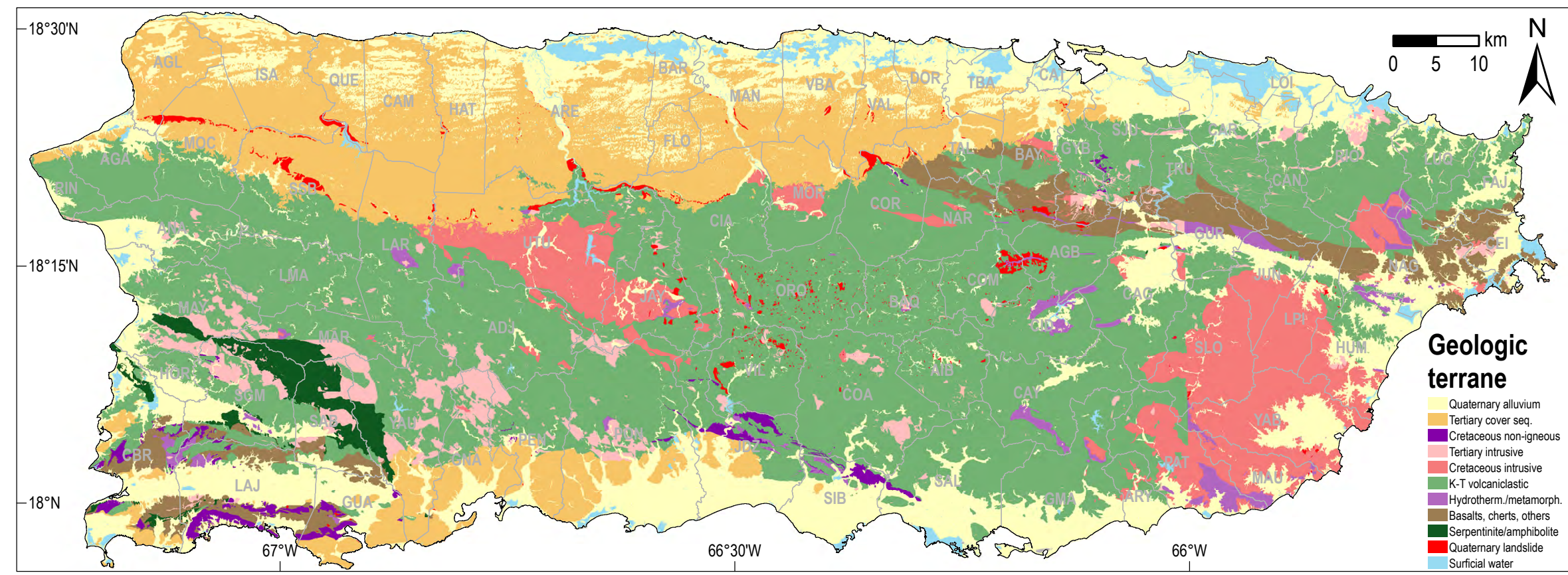

Figure 20. Digitized 1:20,000 geologic map units of Puerto Rico (from U.S. Geological Survey quadrangle maps) categorized using the scheme of Bawiec (1998). The bedrock basement complex of the island is mostly volcaniclastic rocks intruded by small to large plutons. Basement rocks in the north and south parts of the island are unconformably overlain by a sequence of mostly limestone units. Explanation of municipality abbreviations can be found in appendix 1. (km, kilometer; seq., sequence; hydrotherm., hydrothermal; metamorph., metamorphic) 


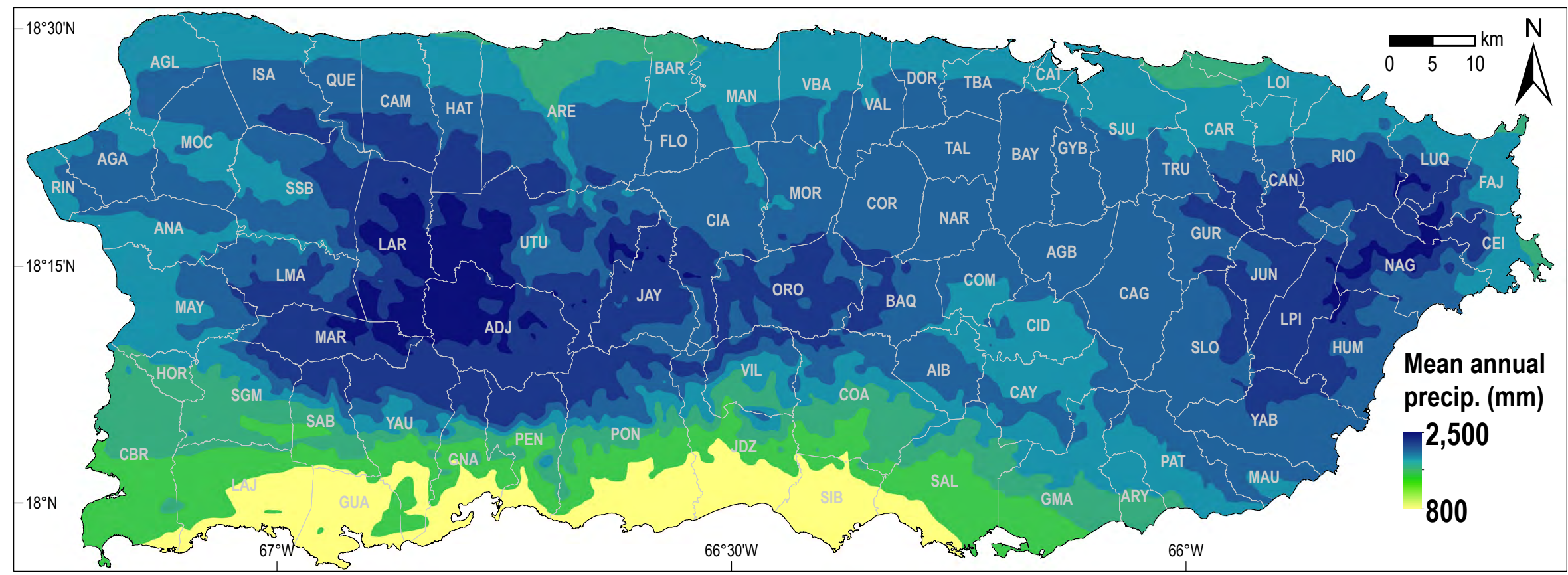

Figure 21. Mean annual precipitation in Puerto Rico (modified from Fick and Jijmans, 2017). The highest yearly rainfall amounts are in the Sierra de Luquillo and in the western interior regions of the island. The south coast is a more arid, rain shadow zone. Explanation of municipality abbreviations can be found in appendix 1. (km, kilometer; mm, millimeter; precip., precipitation) 
Schulz, 2020) reveal that "Moist grasslands and pastures" cover 25 percent of the island and the next highest classifications of "Montane wet evergreen abandoned/active coffee plantation," "Young secondary lowland moist noncalcareous evergreen forest," and "High density urban development" each represent about 6 percent of the island's total area.

Soils in Puerto Rico are diverse, and include 10 of the 12 taxonomic classes (Muñoz and others, 2018). The only soils not found on the island are permafrost-related and active volcano-related soils. Detailed soil surveys of the island were started after U.S. acquisition (Dorsey and others, 1903) and continued throughout the remainder of the 20th century and into the 21st century (Roberts, 1942; Carter, 1965; Gierbolini, 1975; Boccheciamp, 1977, 1978; Gierbolini, 1979; Acevido, 1982; Huffaker, 2002; Lugo-Camacho, 2008). The result of the compilation and digitization of soils data by the U.S. Department of Agriculture Natural Resources Conservation Service is a high-resolution soils dataset of the complete island. The soil class vector file was rasterized to 5-m resolution and used in the analysis for this study (fig. 24). The soil unit numerical key code (mapunit key [MUKEY]) is used to define unique soil units because similar names and acronyms exist for distinct soil classes in separate study regions. The dataset includes 697 unique MUKEY values (table 3; app. 3; Hughes and Schulz, 2020). Some of these MUKEY values are assigned to identical soil units that exist in more than one regional soil survey area. However, the distinct MUKEY classes were not aggregated for the analysis so that as much spatial diversity could be explored as possible. The soils that are most widespread are the Mucara clay (40-60 percent slopes), the Tanamá complex rock outcrop (12-60 percent slopes), and the Caguabo clay loam (40-60 percent slopes) that cover 3.4, 2.8, and 2.5 percent of the island, respectively. Approximately 3 percent of the island is classified as "No Digital Data Available" or "Not Public Information." These locations mostly lie in urban areas and (or) closed Federal lands and were analyzed as independent soil units consistent with all soil unit analyses. For the purpose of this study, the actual composition of the local soils is not of importance, given that each area has an individual MUKEY classification and can be analyzed for landslide correlation.

Typically, landslide occurrence initiated by intense rainfall positively correlates with the cumulative rainfall amount because infiltration of precipitation elevates pore-water pressures, which consequently decrease effective normal stress and shear strength within potential shear zones (Terzaghi, 1950). Hurricane María produced rainfall amounts sufficient to trigger landsliding across all mountainous areas of Puerto Rico (Bessette-Kirton and others, 2019), making it an opportune event for the analysis of landslide susceptibility. However, precipitation amounts from Hurricane María were spatially variable, as they were from Hurricane Irma about 2 weeks prior, which can create event-specific bias in the results of susceptibility analyses such as the one described herein. In an attempt to account for and remove this bias from the susceptibility map, FR analysis of the landslide inventory and root-zone (0-100 centimeters $[\mathrm{cm}]$ depth) soil moisture estimated by the NASA SMAP mission for 9:30 am Atlantic Standard Time on 21 September 2017 (the day after Hurricane María; NASA, 2017), was carried out. As described by equation 4, the SI results for SMAP data were removed from the aggregate Susceptibility Index and resulting susceptibility map. Because of the failure of the local Doppler radar (National Weather Service Public Information Sheet, 2017) and many rain gage stations at various times during the passage of the storm, the precipitation estimates across the island for the event are quite variable (Bayouth García and others, 2018). In addition, soil moisture is a subsurface parameter that represents interception of precipitation, runoff, and infiltration and is a more accurate proxy for pore-water pressure conditions than rainfall data. Bessette-Kirton and others (2019) found stronger correlation between María-induced landslide density and the SMAP data than with available rainfall data. Figure 25 shows the SMAP data, which depict volumetric water content (volume of water/volume of soil) on a 9-km gridded basis. For the chosen sensor pass, soil moisture was generally higher in the mountainous interior of the island than around the perimeter, although high amounts were also present along the north-central and northwestern coastlines. The raw SMAP data were resampled to 5-m pixel size and interpolated using cubic convolution to provide a more realistic, smoother distribution of soil moisture values for use in this analysis (fig. 26).

In addition to all datasets being set to 5-m resolution, they were all processed in the same projection: WGS 84/UTM Zone 19N. The final data product is also registered in the same coordinate system. Certain datasets were analyzed but not used in the final model. Among others, these include hillslope aspect, elevation above sea level, and proximity to faults. Aspect was not used to preclude bias from event-specific conditions. In addition, a pilot study of the inventory dataset and a full island aspect map resulted in very little distinction with regards to aspect (Lugo Bendezú and others, 2018). This analysis also revealed that almost equal numbers of hillslopes are facing each cardinal direction on the island. Generally, tropical cyclones approach Puerto Rico from the east-southeast, which is important in terms of wind effects across ridge crests. However, the data used in this study do not demonstrate that directional rainfall had any effect on slope failure control. Elevation was rejected as a model input because there are notable low-relief upland zones (Lobeck, 1922; Meyerhoff, 1927; Monroe, 1980b; Brocard and others, 2015; Santiago-Pérez and others, 2019) as well as coastal cliff areas across the island; increase or decrease in altitude alone has no control on landslide potential. Relief rasters with various radii were explored, but this metric was also not included as a model input because relief over any given distance does not represent site-specific hillslope conditions as well as slope inclination. Proximity to a fault trace was not incorporated in the model due to the variability of fault mapping from quadrangle to quadrangle and the unknown positional precision of mapped faults. 


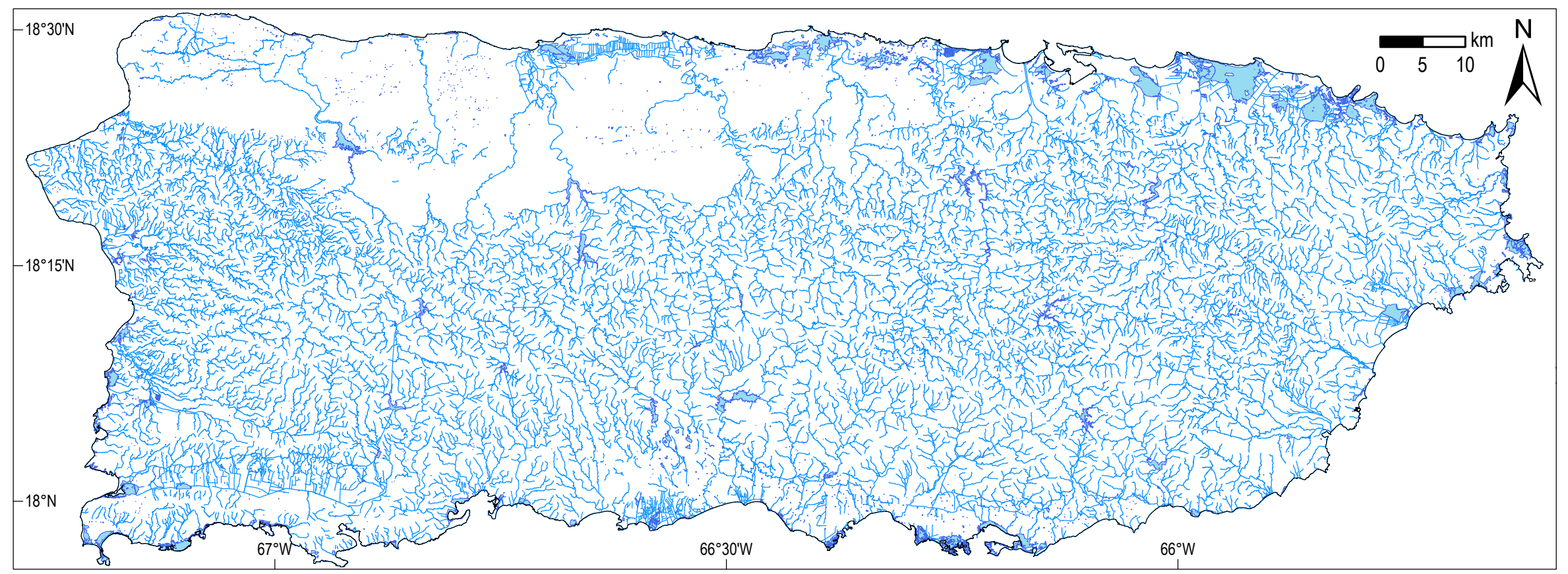

Figure 22. Fluvial channels for Puerto Rico from the National Hydrography Dataset geodatabase file (U.S. Geological Survey, 2019). The northcentral/northwest coast is characterized by sinking streams and subterranean flow through the karst region. Most of the remainder of the island has dendritic drainage patterns. Rivers follow prominent fault zones at various locations across the island. ( $\mathrm{km}$, kilometer) 


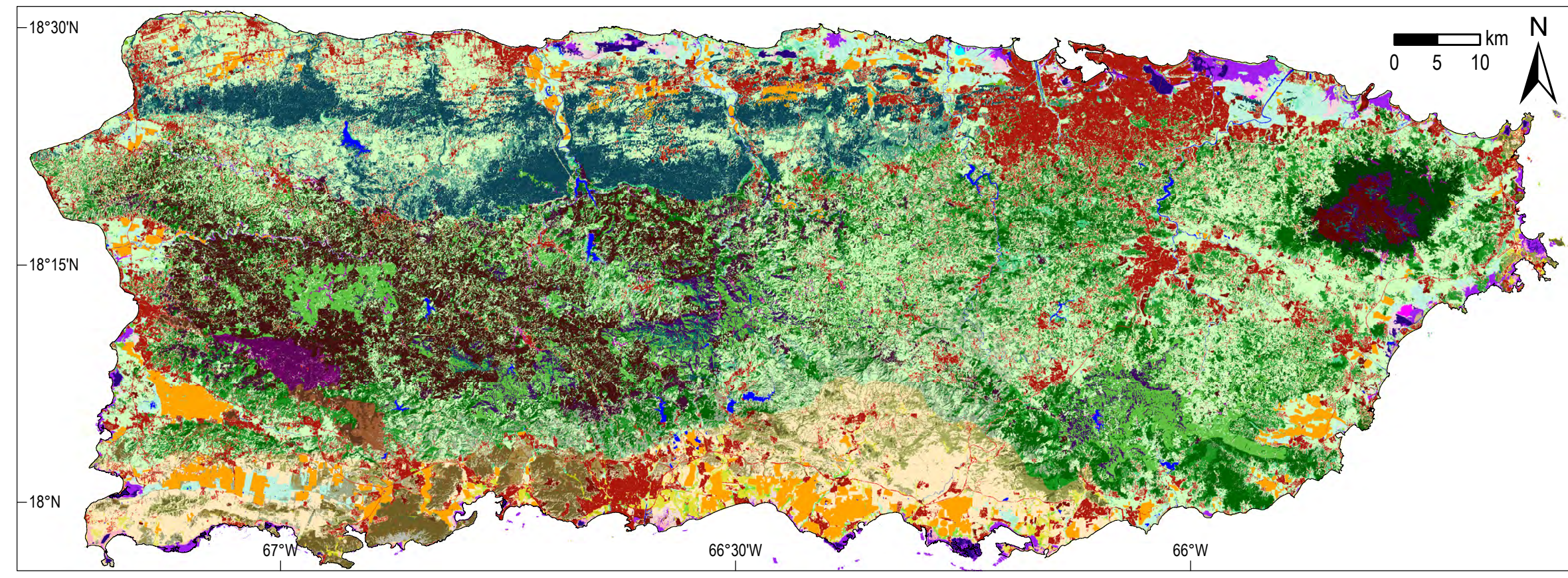

Figure 23. Puerto Rico Gap Analysis Program land cover dataset (modified from Gould and others, 2008). Data are derived from Landsat analysis and include 66 unique classes. Legend not included as map is intended to show diversity of land cover classifications, not exact classes. (km, kilometer) 


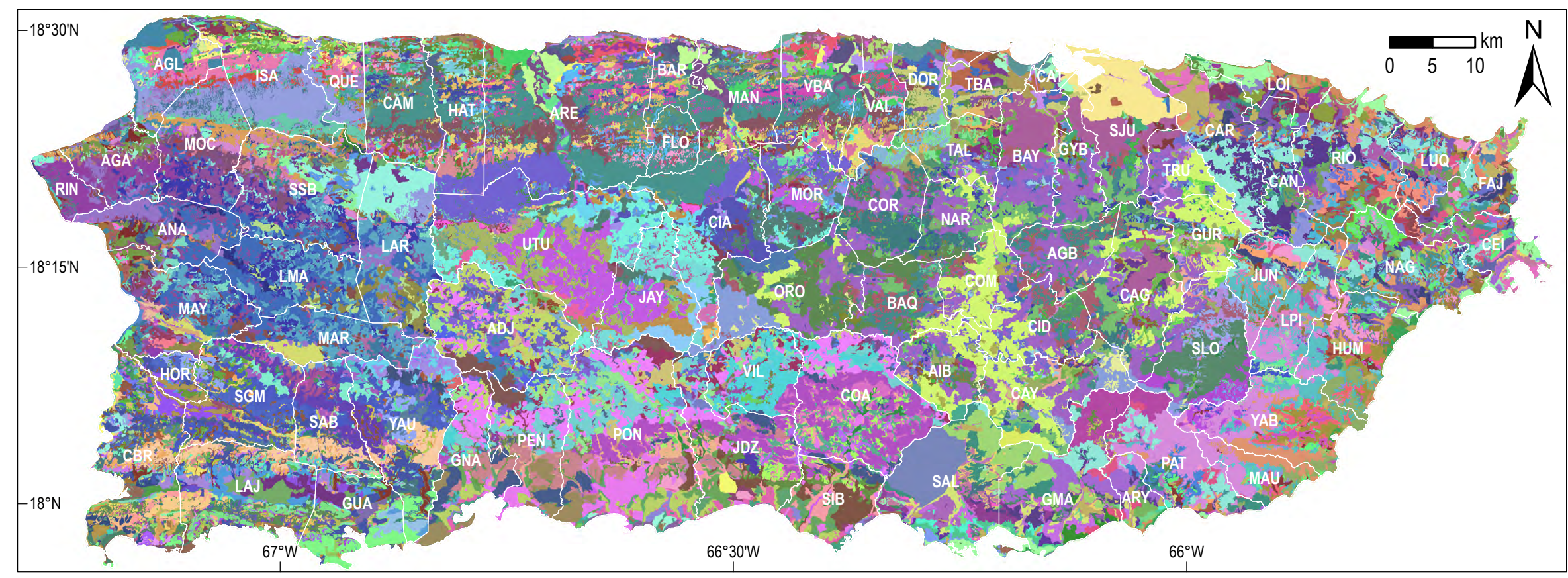

Figure 24. U.S. Department of Agriculture (USDA) Natural Resources Conservation Service soil classification map for the island of Puerto Rico (USDA, 2018). Color is based on mapunit key (MUKEY) classifications which yield 697 unique classes. Similar colors across the map do not necessarily indicate similar soils. This is because of the large number of classes, which results in colors being repeated for dissimilar units. Explanation of municipality abbreviations can be found in appendix 1. (km, kilometer) 


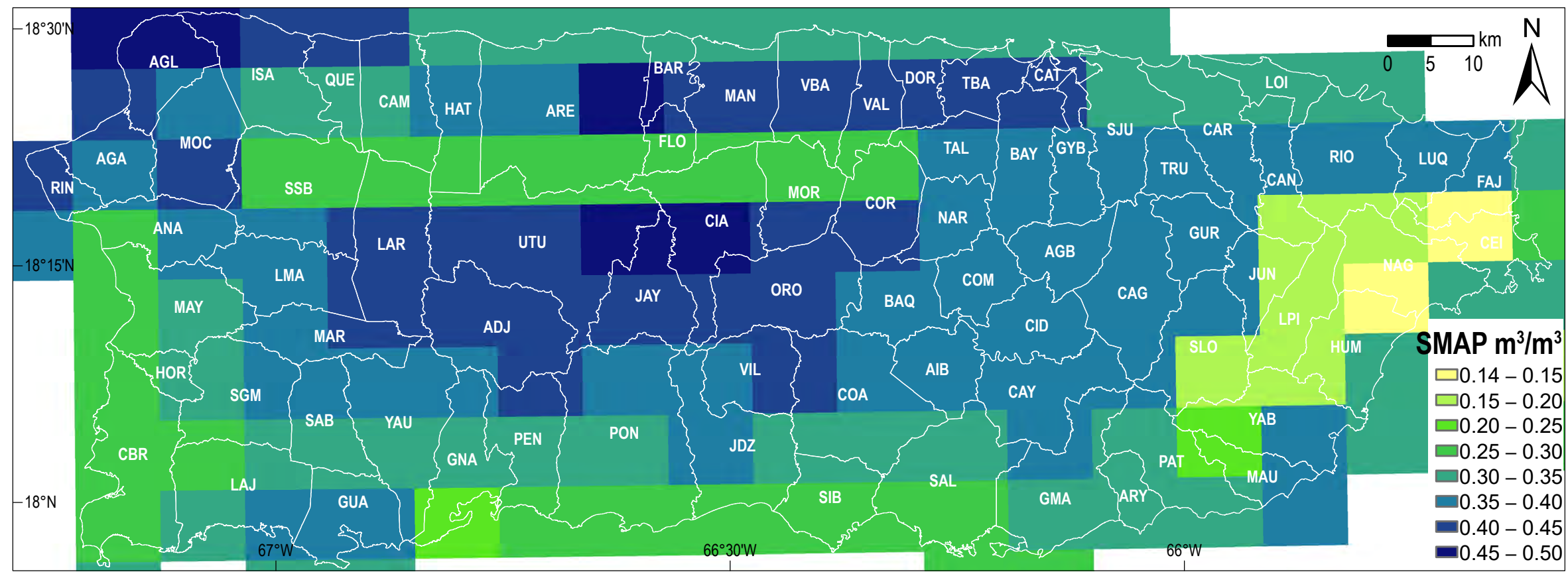

Figure 25. Raw Soil Moisture Active Passive (SMAP) root zone soil moisture data for 9:30 a.m. Atlantic Standard Time on 21 September 2017 (National Aeronautics and Space Administration, 2017). Soil moisture is reported as volumetric water content (volume of water/volume of soil). Explanation of municipality abbreviations can be found in appendix 1. ( $\mathrm{km}$, kilometer; $\mathrm{m}^{3}$, cubic meter) 


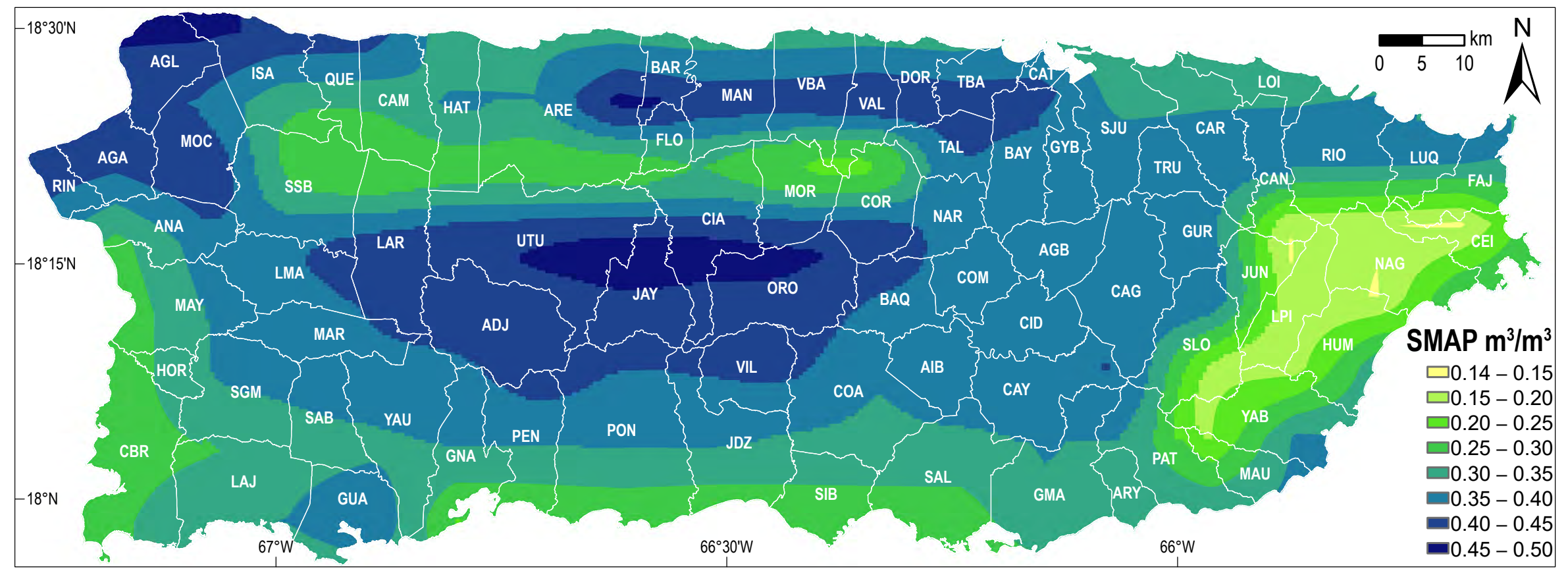

Figure 26. Interpolated root zone soil moisture data from Soil Moisture Active Passive (SMAP) at 9:30 a.m. Atlantic Standard Time on 21 September 2017. Soil moisture is reported as volumetric water content (volume of water/volume of soil). Explanation of municipality abbreviations can be found in appendix 1. (km, kilometer; $\mathrm{m}^{3}$, cubic meter) 


\section{Results and Discussion}

The results of the FR analyses and the corresponding landslide $S I$ values are reported in table 3, appendixes 2 and 3, and figures 27-35. A summary of the $S I$ values and cumulative $S I A_{m}$ is shown in table 4. In general, the results follow expected factor correlations, which act as a form of independent check on the quality of the inventory product used. The $S I$ color scheme for figures $27-35$ is consistent with a range of 5.00 to -5.00 , such that 0 lies at the neutral color. Full maximum and minimum color saturation is at $S I$ values of 2.00 and -2.00 . The highest $S I$ value calculated for any factor bin is 2.64 (Pellejas clay loam soil unit) and the lowest $S I$ values were limited to -5.00 . These criteria were used to temper the effect of (1) extremely negative $S I$ values that may have been a result of very small bin areas or (2) bins that had a FR value of 0.

\section{Factor Performance}

Results of analyses of slope inclination and the landslide inventory (table 3, fig. 27A-B) show that landslides were more numerous as slope inclination increased to $45^{\circ}$. Slope values of less than $25^{\circ}$ have $S I$ values less than 0 , indicating they are less likely to fail. Slopes between $25^{\circ}$ and $45^{\circ}$ show linear increase in $S I$ (logarithmic increase in FR) to a maximum value of 1.59 for the $40-45^{\circ}$ bin. Slopes between $45^{\circ}$ and $90^{\circ}$ represent only 2 percent of the island and have a lower $S I$ value at 1.05 . The lower $S I$ in this highest slope bin may be a result of a combination of the failure mechanism and identification potential of landslides at very steep sites. As slope increases, the depth of landslide-susceptible soil decreases and the potential for rockfalls becomes higher than the potential for slumps, slides, or flows. Rockfalls are often less evident than debris flows when using aerial photographs to catalog failure sites. Another potential contributing factor for the lower $S I$ value for slopes greater than $45^{\circ}$ is that vertical or near-vertical limestone cliffs in the northern karst province represent much of the bin values for the island and landslides were relatively rare in this region (Hughes and others, 2019). Specific results of the geologic substrate analysis are discussed in the following three paragraphs.

Results from the curvature analysis (table 3, fig. 28A-B) show that planar or nearly planar areas have the lowest correlation with landslides in the inventory. Pixels that were classified as planar or nearly planar have a $S I$ value of -1.17 , which is the lowest for the factor. For slopes that are either more concave (+) or more convex (-), the $S I$ values increase to maxima of 1.54 and 0.87 , respectively, indicating that landslides commonly occurred in valleys and on ridges. The most extreme values of concavity and convexity have neutral to negative $S I$ values (table 3).

Table 4. Susceptibility Index (S/) values for potential landslide-contributing factors.

[max, maximum; min, minimum; std. dev., standard deviation; $S I A_{m}$, final modified $S I$ value at each 5-m pixel islandwide]

\begin{tabular}{|c|c|c|c|c|c|}
\hline Factor & $S I \max$ & $S / \min$ & SI range & $S /$ mean & SI std. dev. \\
\hline Slope & 1.59 & -3.60 & 5.19 & -0.32 & 1.62 \\
\hline Curvature & 1.54 & -1.17 & 2.71 & 0.24 & 0.80 \\
\hline $\begin{array}{l}\text { Proximity to road } \\
\text { surface }\end{array}$ & 0.24 & -2.48 & 2.72 & -0.38 & 0.85 \\
\hline Geologic terrane & 1.33 & ${ }^{1}-3.73$ & ${ }^{1} 5.06$ & ${ }^{1}-0.85$ & ${ }^{1} 1.57$ \\
\hline $\begin{array}{l}\text { Mean annual precipi- } \\
\text { tation }\end{array}$ & 1.24 & ${ }^{2}-8.00$ & ${ }^{2} 6.24$ & ${ }^{2}-1.59$ & ${ }^{2} 2.26$ \\
\hline $\begin{array}{l}\text { Proximity to fluvial } \\
\text { channel }\end{array}$ & 0.29 & -3.73 & 4.02 & -0.46 & 1.21 \\
\hline Land cover & 1.42 & $\left({ }^{3}\right)$ & ${ }^{3} 6.42$ & ${ }^{3}-2.78$ & ${ }^{3} 2.25$ \\
\hline Soil classification & 2.64 & $\left(^{3}\right)$ & 37.64 & $3-3.00$ & ${ }^{3} 2.20$ \\
\hline Event soil moisture & 1.67 & -1.91 & 3.58 & -0.51 & 1.16 \\
\hline Cumulative $S I A_{m}$ & 1.97 & -4.84 & 6.81 & -1.36 & 1.74 \\
\hline
\end{tabular}

${ }^{1}$ The -5.14 value for surficial water bodies category is not included.

${ }^{2} S I$ values less than -5.00 were set to -5.00 to minimize the statistical influence of subfactors that cover very small areas and (or) include very few landslides. The range, mean, and standard deviation above were calculated using -5.00 as a minimum value.

${ }^{3}$ Some categories of land cover and soil classification included sites with no landslides. The resultant frequency-ratio value is 0 and the natural log of 0 goes to negative infinity. In these cases, the $S I$ value was set to -5.00 . The range, mean, and standard deviation above were calculated using -5.00 as a substitute for all negative infinity returns. More detailed data results are in table 3 and appendixes 2 and 3. 
Similar to the results from Larsen and Parks (1997), the analysis of the landslide inventory with respect to road surface proximity shows that sites within $100 \mathrm{~m}$ of a road were more likely to correlate with landsliding than those farther away. The highest $S I$ values are 0.12 and 0.24 , which correlate with bins that represent pixels within $0-10 \mathrm{~m}$ and $10-25 \mathrm{~m}$, respectively, of a paved road surface. The results are tabulated in table 3 and displayed visually in figure $29 A-B$.

The results from the analysis of geologic substrate (table 3, fig. 30) show that local geology was important to mass wasting susceptibility during Hurricane María. Of the 11 terrane classifications (including surface water), only 3 show positive correlation to the landslide inventory. The Cretaceous intrusive rock category shows the most correlation and has a SI value of 1.33. The majority of this category is made up of the mostly granodiorite Utuado and San Lorenzo plutonic bodies. The CretaceousTertiary volcaniclastic terrane, which is the most widespread geologic classification on the island, has a positive SI value of 0.38. Most classes are negatively correlated, including the Tertiary cover sequence rocks $(-2.12)$ and Quaternary alluvium $(-3.27)$. The surficial water body classification $(-5.14)$ includes seven sites (less than 0.01 percent of the inventory dataset) in the mass wasting catalog. These sites represent locations on the lateral limit of water bodies where the geologic mapping overextended the extent of water coverage. Zones mapped as Quaternary landslides yield an $S I$ value of -0.34 , indicating that these zones of deep mass movements mostly mapped by Monroe (1979) did not frequently produce landslides during Hurricane María. The highest landslide correlation for the Cretaceous intrusive rocks classification is linked to the manner in which these plutonic rocks react to chemical weathering in Puerto Rico, which has been shown to be among the most rapid in the world (White and Blum, 1995). Specifically, as the granodiorite rock suffers chemical weathering in the humid tropical environment, most minerals experience dissolution or hydrolysis and are transported away in groundwater solution (White and others, 1998; Porder and others, 2015). However, the abundant quartz in the bedrock remains mostly unaffected and the result is a sandy residuum (Mattson, 1968). This product has very low cohesion and is more vulnerable to mobilization when pore-water pressures increase due to rainwater (or other) saturation. The regolith generated from rock types other than the granodiorite is generally more clay rich and more cohesive.

Mean annual precipitation shows a strong correlation with landslide sites. Only one landslide site was cataloged in zones that receive less than 1,000 millimeters $(\mathrm{mm})$ of rain annually. The $1,750-2,000 \mathrm{~mm}$ bin is nearly neutral with a SI value of 0.06 and the highest bin of 2,250-2,500 $\mathrm{mm}$ has the highest $S I$ value of 1.24. In general, areas that receive more rainfall are more prone to experience hillslope failure due to the increased rates of chemical weathering and (or) fluvial incision resulting from higher rainfall amounts. These results are summarized in table 3 and shown graphically in figure $31 A-B$.

The analysis of proximity to fluvial channel (table 3, fig. 32A-B) reveals that sites within $25 \mathrm{~m}$ and in excess of $400 \mathrm{~m}$ from a flow line representing each channel are statistically less likely to experience mass wasting. Bins of between $25-\mathrm{m}$ and $400-\mathrm{m}$ distance show correlation with failure sites. The lower SI values for sites within $25 \mathrm{~m}$ of fluvial channels is interpreted to result from some of this distance being the channel itself (the hydrographic data provide a line near channel axes) and low-susceptibility floodplains that are associated with many fluvial channels. Most of the island that is more than $400 \mathrm{~m}$ from a fluvial channel is in the topographically complex northern limestone and karst region where landslides were rare during Hurricane María (Hughes and others, 2019).

Land cover analysis shows variability among the 66 distinct categories classified as part of the GAP dataset (table 3; fig. 33; app. 2; Hughes and Schulz, 2020). The "Montane wet evergreen abandoned/active coffee plantation" class yields the highest SI value of 1.42 . This high correlation is likely due to the disturbance of natural slopes by centuries of agricultural activity, especially the creation of improvised, rudimentary farm roads throughout the mountainous areas where coffee is cultivated (Philpott and others, 2008; Ramos-Scharrón and LaFevor, 2016). The "Montane wet noncalcareous evergreen shrubland and woodland" category has a similar $S I$ value of 1.37 . Twenty-three land cover classes did not include any landslide sites; these are generally wetland, beach, water, and arid categories.

Soil class (table 3; fig. 34; app. 3; Hughes and Schulz, 2020) is perhaps the best nonslope factor to distinguish zones susceptible to mass wasting. In addition, the highest $S I$ values for any factor of the study are related to specific soil types. Both the "Pellejas clay loam (40-60 percent slopes)" and "Maricao clay (20-60 percent slopes)" classes yield SI values greater than 2.5. Another 28 soil classes have $S I$ values greater than 1.0 and an additional 58 classes have $S I$ values greater than 0 . Of the 697 total classes, 317 have no association with any landslide in the inventory. The detailed soil classification is an important model input and acts as an effective discriminator within zones that fall in the same geological terrane classification.

The soil moisture analysis (table 3 ; fig. 35 ) shows that the wettest two bins $\left(0.40-0.45\right.$ cubic meters $\left[\mathrm{m}^{3}\right]$ and $\left.0.45-0.50 \mathrm{~m}^{3}\right)$ correlate best with the Hurricane María inventory dataset. The high correlation is because much of the wettest SMAP data registered in the central municipalities of Utuado, Jayuya, Ciales, and Orocovis where many landslides occurred. A comparison with the density map in figure 13 highlights this correlation, especially in the vicinity of Lago Caonillas in east-central Utuado. The results here generally concur with the analysis made by Bessette-Kirton and others (2019). However, the FR relationship between SMAP values and landslide sites does not follow a consistent trend (table 3) considering values of soil moisture less than 0.25 ; SI increases with increasing soil moisture greater than 0.25 . This suggests that soil moisture of 0.25 or greater was required to initiate widespread landsliding. 


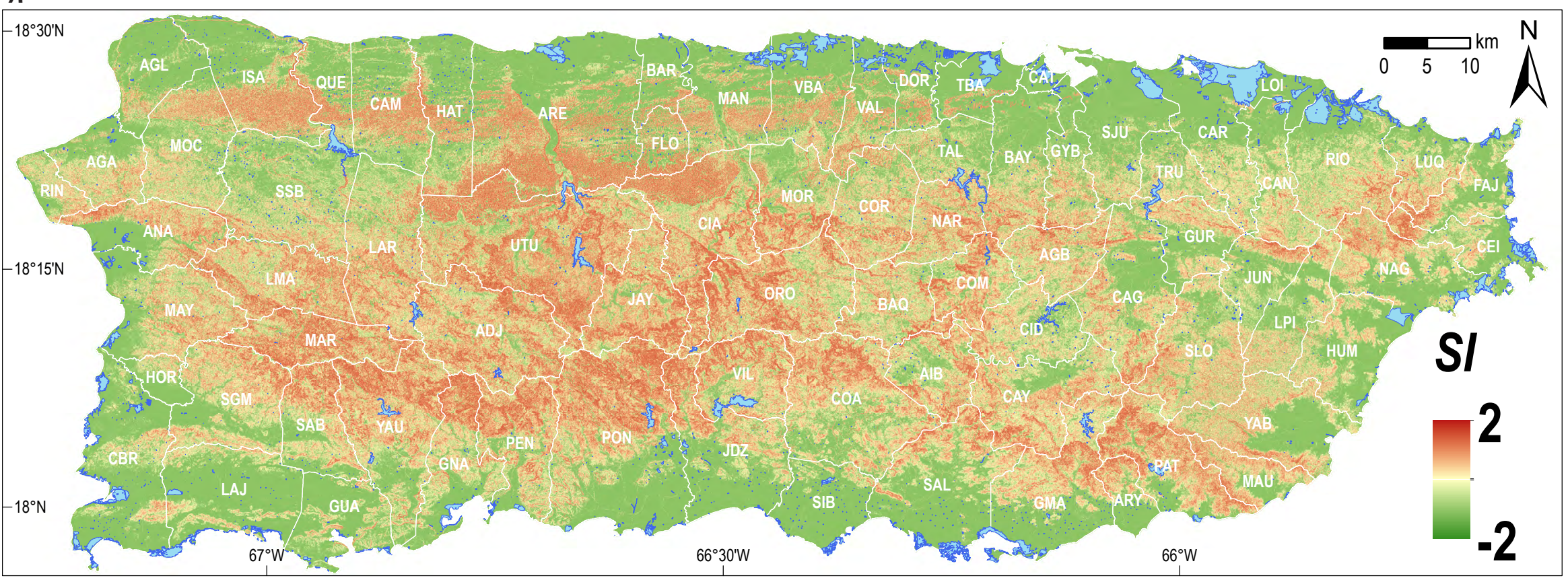

$B \quad$ Slope

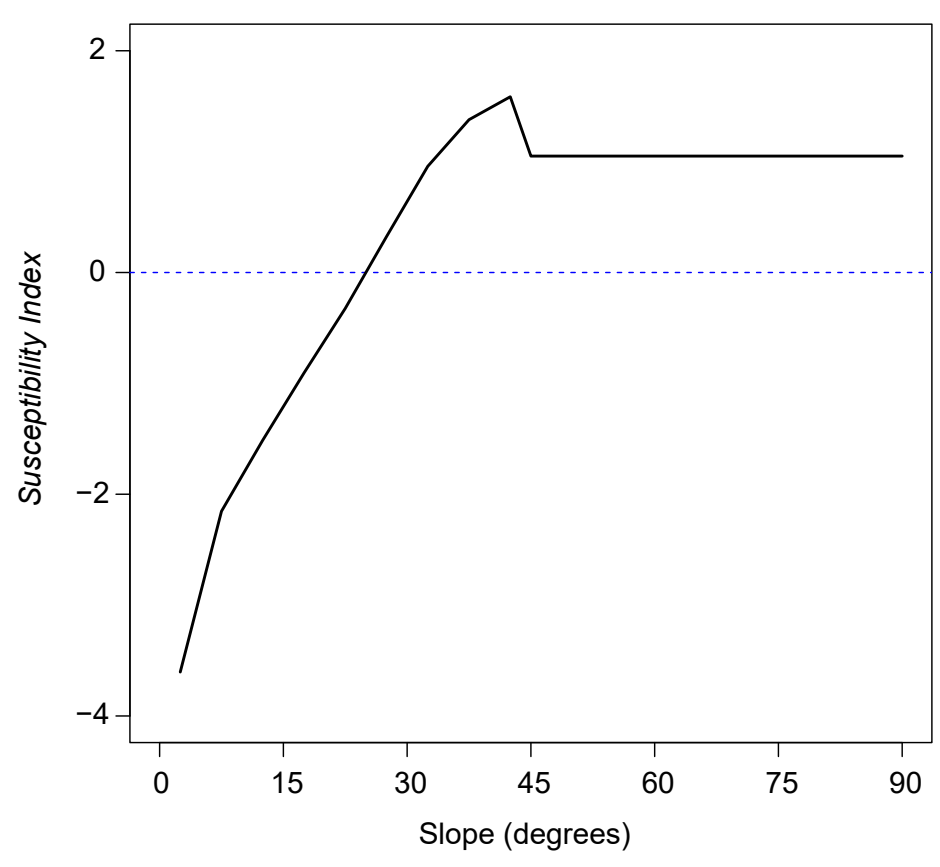

Figure 27. Results and representation from the slope Susceptibility Index $(S /)$ analysis. $A$ Higher slopes across the island correspond to higher $S /$ values. The range of slope $S /$ values is from -3.60 to 1.59. The zone in southeastern Puerto Rico, mostly within Cayey (CAY) and Guayama (GMA) for which data are missing from the 2015-2016 airborne lidar survey, is not readily evident in the analysis. Compare to figure 15. Explanation of municipality abbreviations can be found in appendix 1 (km, kilometer). B, Graphical representation of the slope factor $S I$ analysis results. 


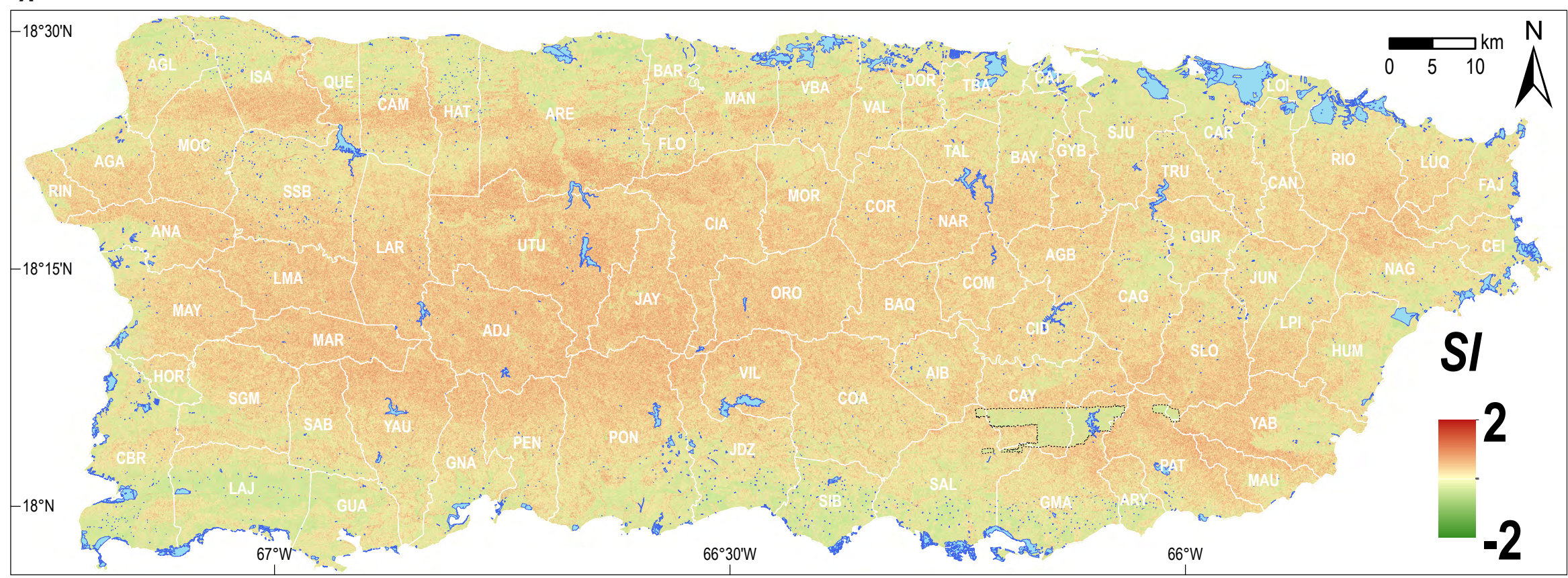

$\boldsymbol{B}$

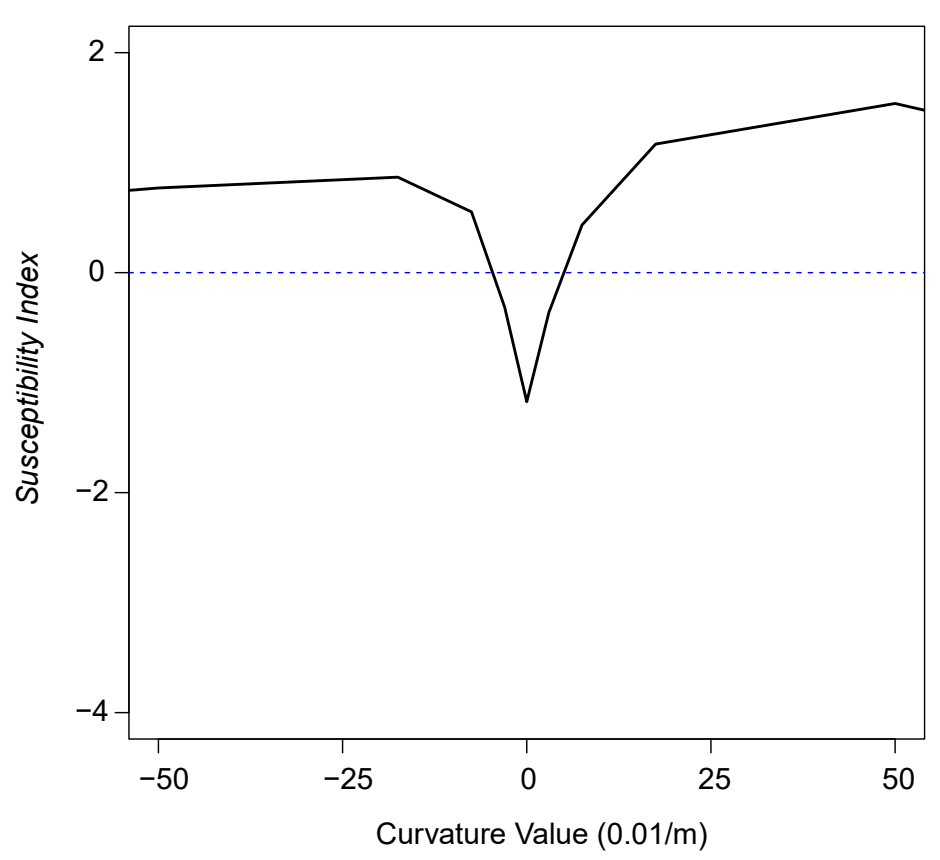

Figure 28. Results and representation of the curvature Susceptibility Index $(S /)$ analysis. $A$, In general, more mountainous regions are home to more concave and convex sites. The range of values for curvature is from -1.17 to 1.54 . The lidar coverage gap zone mostly within Cayey (CAY) and Guayama (GMA) in southeastern Puerto Rico is apparent in this data output. Because these missing zones were "patched" with a data product of inferior quality, the result is a model that shows much flatter terrain than what exists in reality. This leads to an unavoidable underestimation of the curvature $S /$ in these polygonal areas. This underestimation is accepted because lidar coverage for this area was not collected and the curvature $S /$ input represents less than 7 percent of the final $S /$ value at each pixel. Compare to figure 16. Explanation of municipality abbreviations can be found in appendix $1 . B$, Graphical representation of the curvature factor $S /$ analysis results. (km, kilometer; m, meter) 


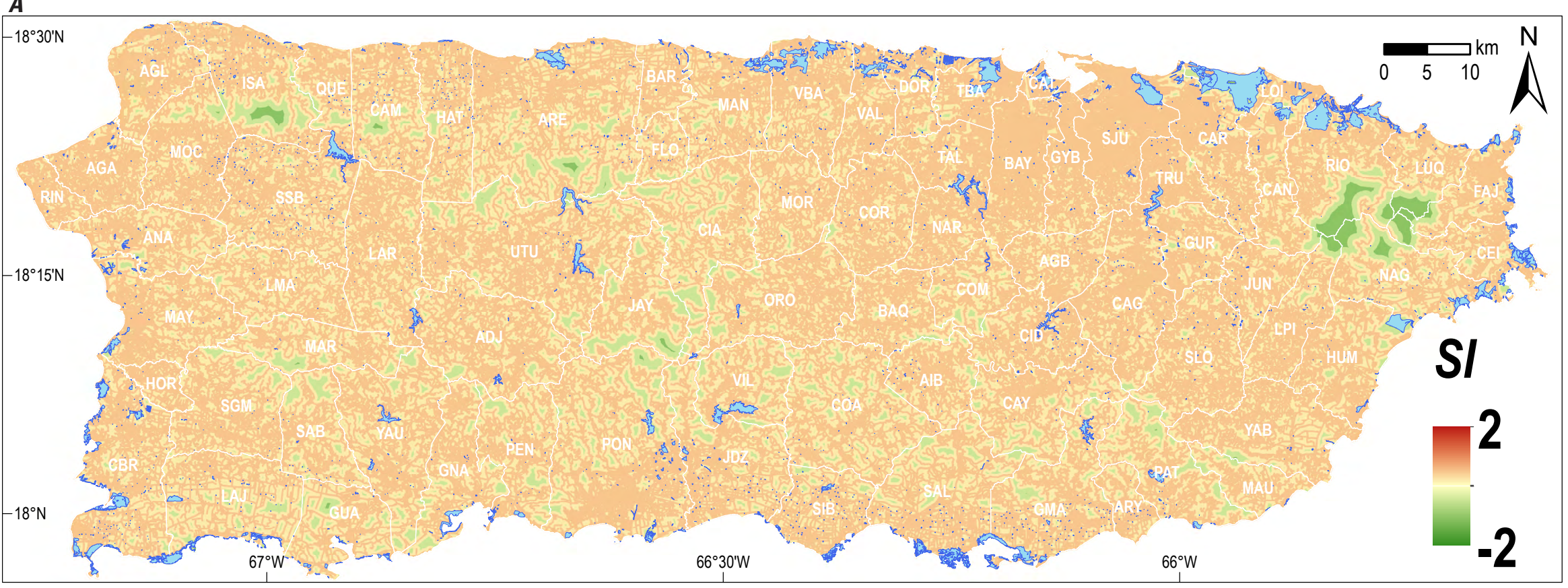

B Proximity to road

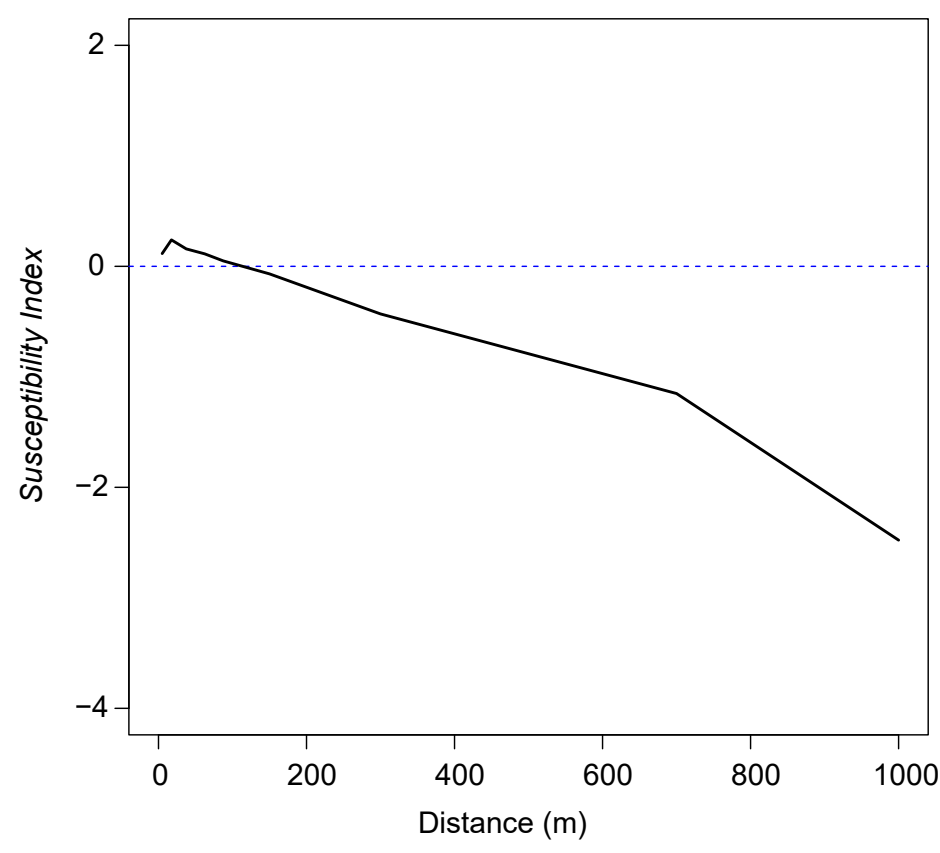

Figure 29. Results and representation from the road proximity analysis. $A$, Sites closer to road surfaces yield higher Susceptibility Index ( $S /$ ) values. Sites more than 1 kilometer from a road have the lowest $S /$ value at -2.45 whereas sites within 100 meters of a road have $S /$ values greater than 0 . Compare to figure 18. Explanation of municipality abbreviations can be found in appendix 1. $B$, Graphical representation of the proximity to road factor $S /$ analysis results. (km, kilometer; m, meter) 


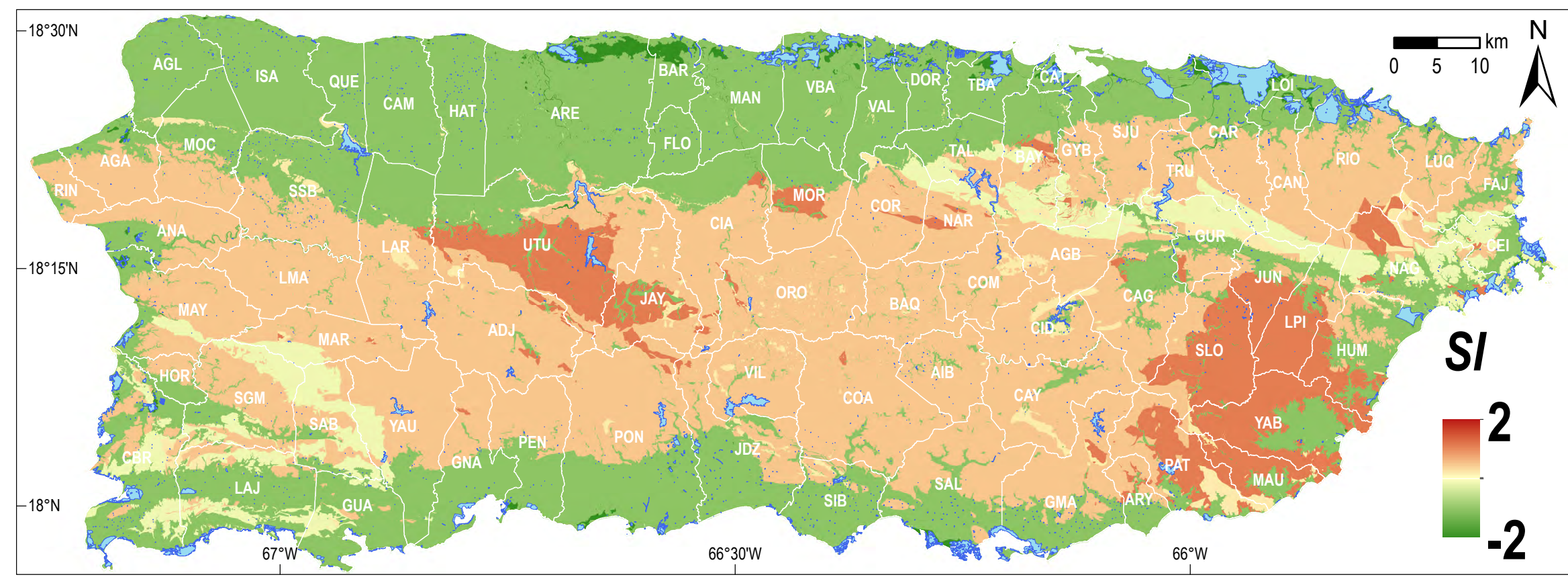

Figure 30. Susceptibility Index $(S)$ results for geological terranes as defined by Baiwec (1998). The Cretaceous intrusive classification shows the strongest correlation with the landslide inventory. The extensive Cretaceous-Tertiary volcaniclastic terrane yields a positive correlation as well. Compare to figure 20. Explanation of municipality abbreviations can be found in appendix 1. (km, kilometer) 


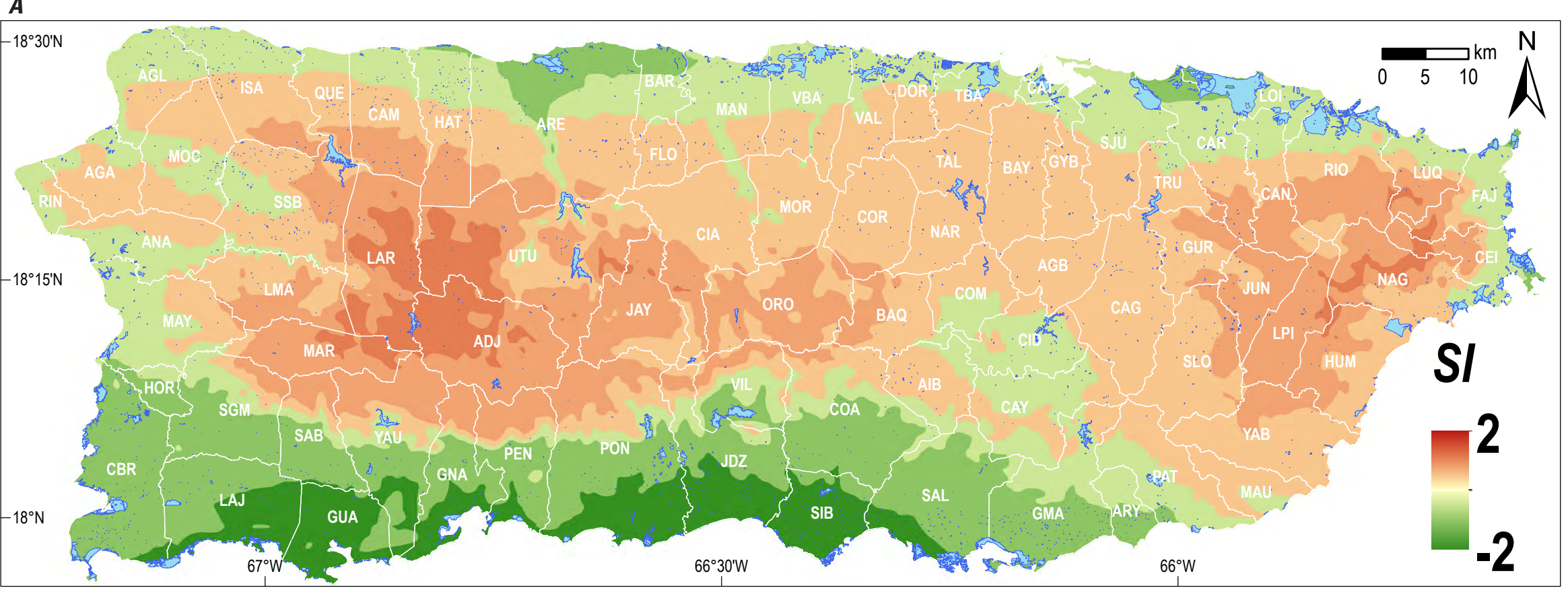

B

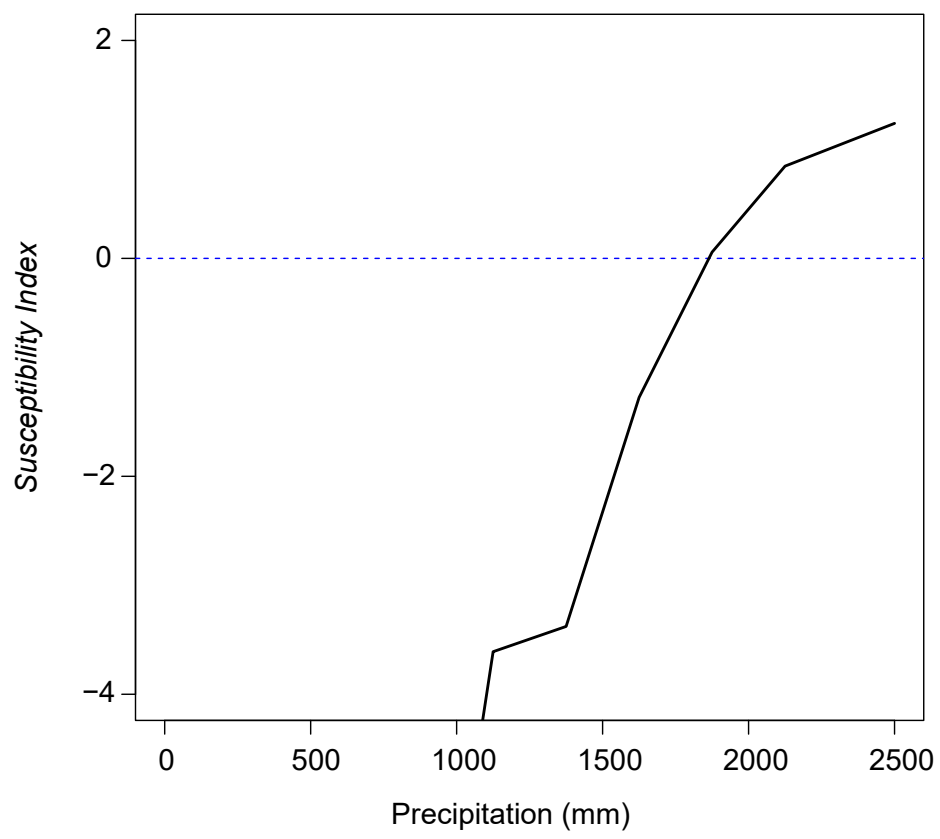

Figure 31. Results and representation from Susceptibility Index (S/) analysis of mean annual precipitation. $A$, Zones of higher mean annual precipitation are more positively correlated to mass wasting sites. The wettest regions in the Sierra de Luquillo and western interior have the highest $S /$ values. The arid south coast region has the lowest correlation with landslide sites in the inventory. Compare to figure 21. Explanation of municipality abbreviations can be found in appendix 1. $B$, Graphical representation of the mean annual precipitation factor $S /$ analysis results. (km, kilometer; $\mathrm{mm}$, millimeter) 


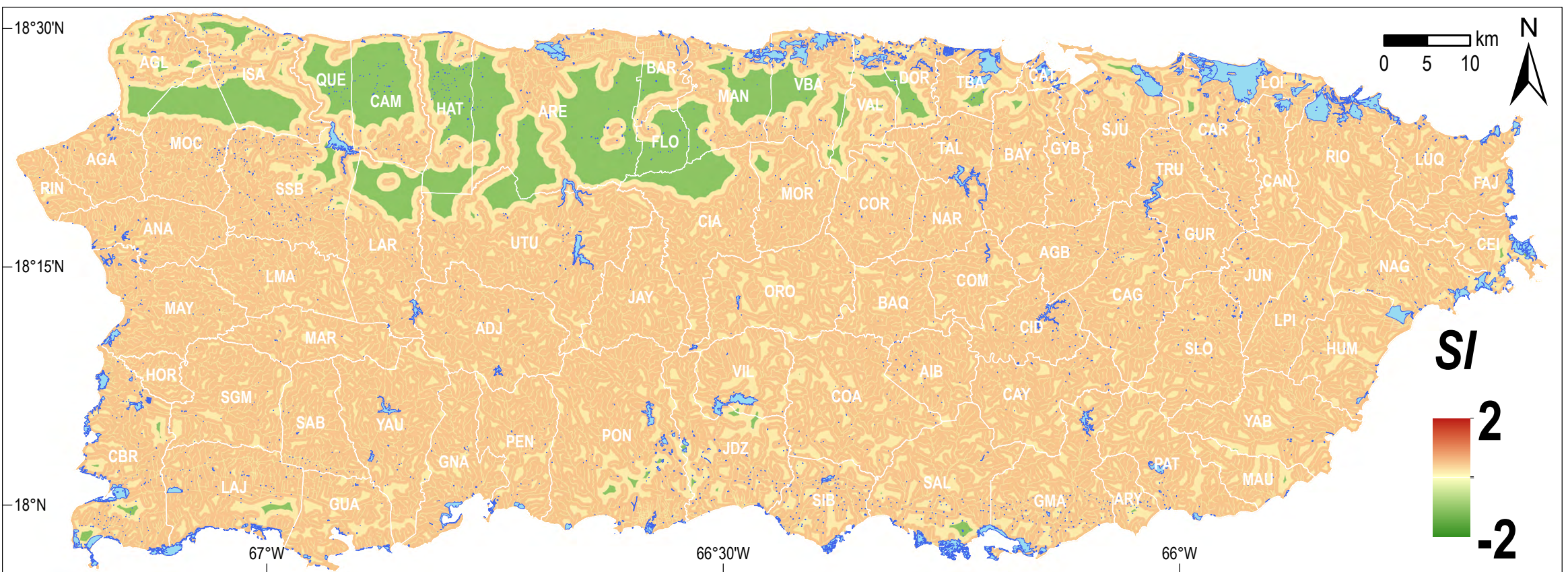

$\boldsymbol{B}$

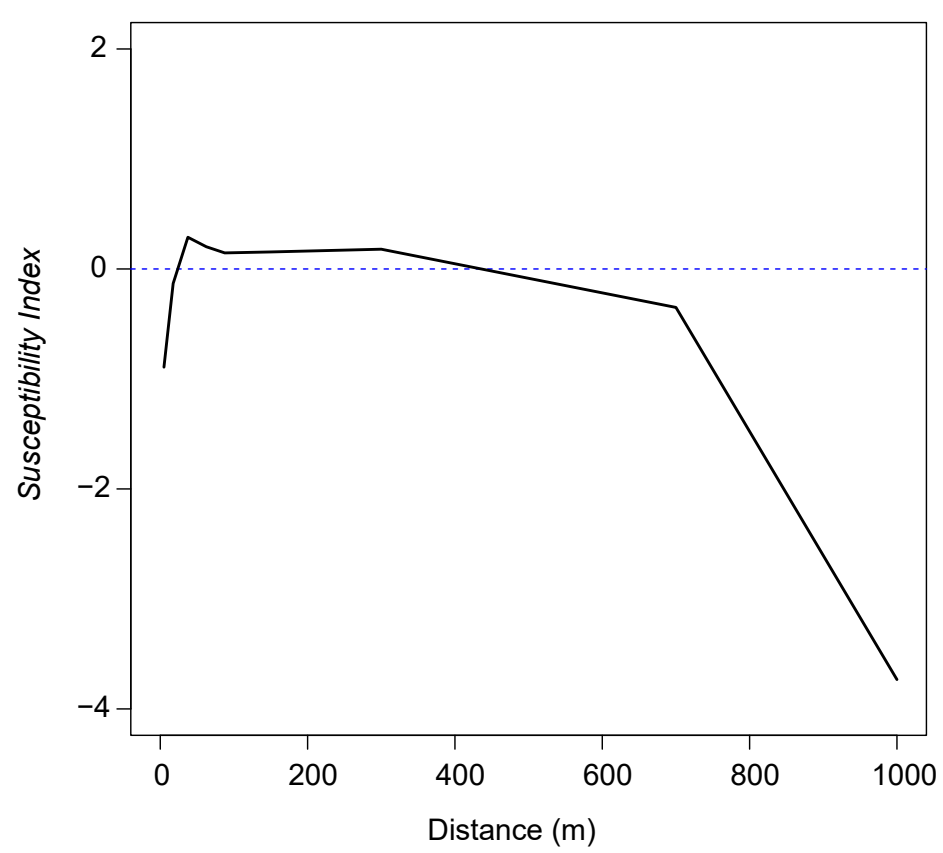

Figure 32. Results and representation from Susceptibility Index (SI) analysis of distance to streams. $A$, Sites farther than $\mathbf{4 0 0}$ meters $(\mathrm{m})$ from surficial fluvial channels are the least correlated to landslide sites. Most other distances are nearly neutral except those within $25 \mathrm{~m}$ of flow lines, which show negative correlation with slope failures. Compare to figure 22. Explanation of municipality abbreviations can be found in appendix 1. B, Graphical representation of the proximity to fluvial channel factor $S /$ analysis results. (km, kilometer) 


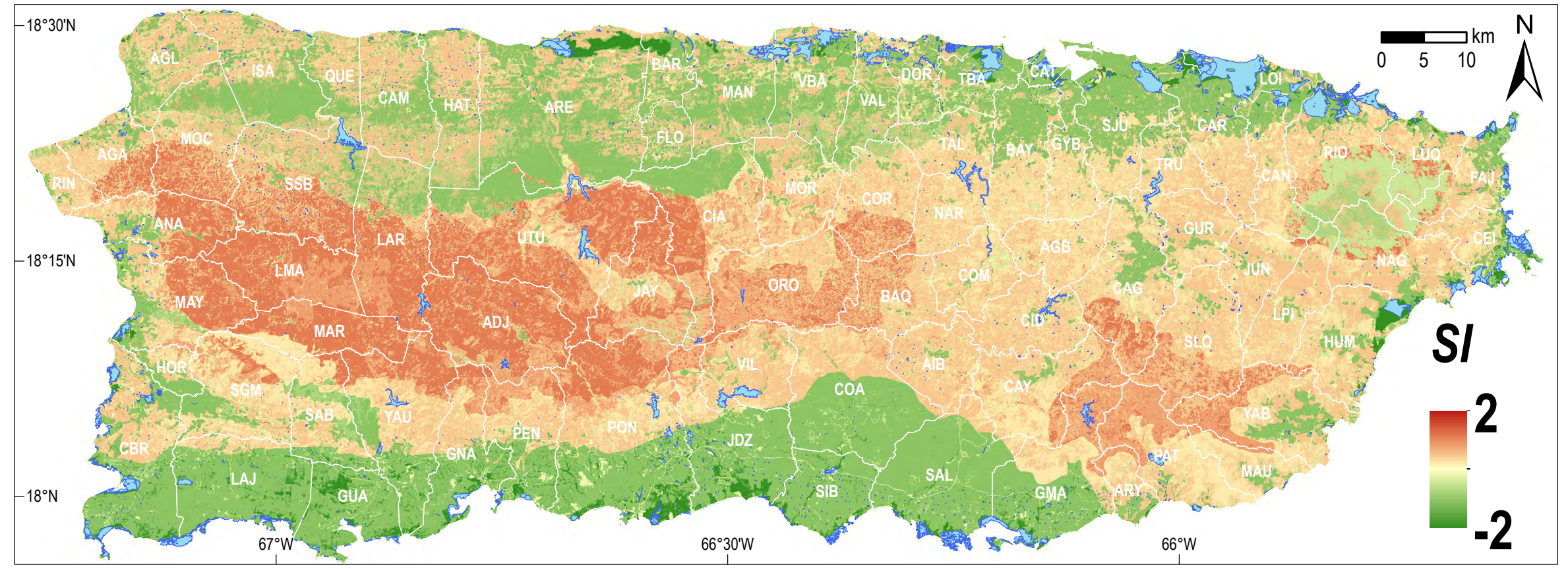

Figure 33. Results from analysis of Susceptibility Index (S/) values for the 66 unique land cover classes. The highest $S /$ value is for abandoned and active coffee farms, which cluster in the rugged western interior of the island. The Sierra de Luquillo is characterized by neutral to negative $S /$ values ringed by a zone of land cover areas that have higher $S /$ values. Wetlands, urban areas, and beaches return very negative $S /$ values. Compare to figure 23. (km, kilometer) 


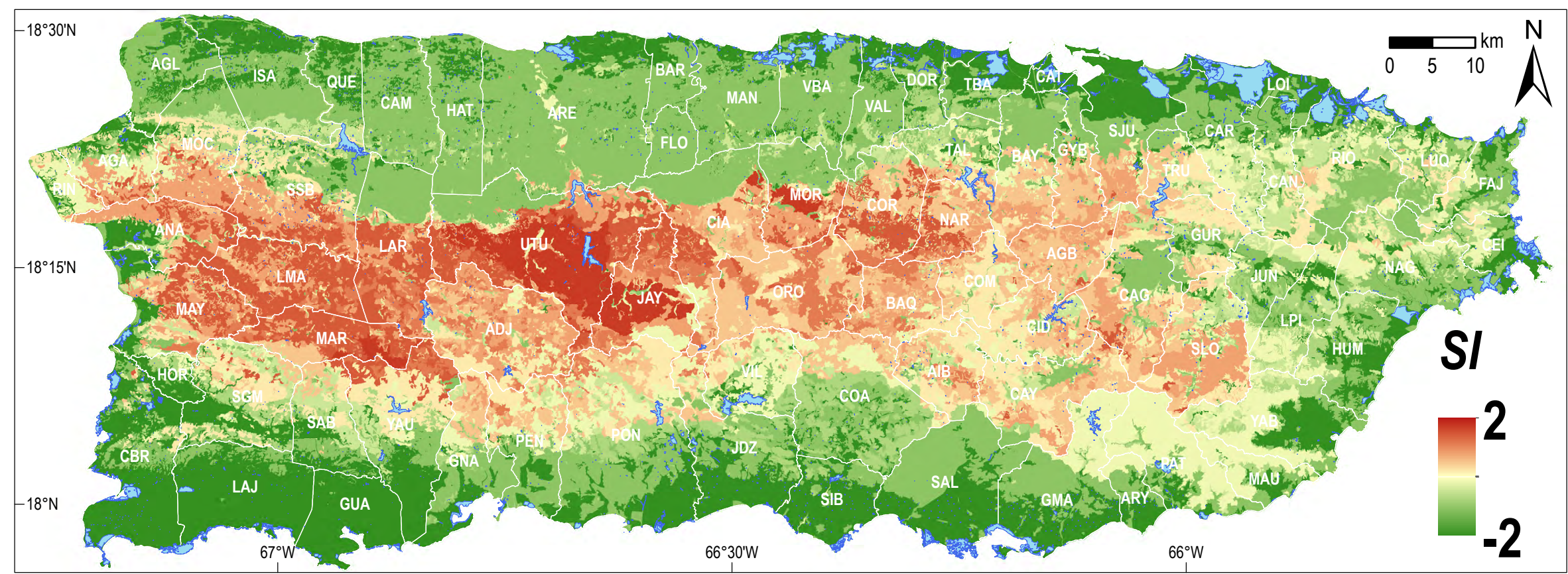

Figure 34. Results from Susceptibility Index ( $S /$ ) analysis of 697 soil classes. The Pellejas clay loam has the highest $S /$ value of any factor in the study at 2.64 and mostly correlates with the Utuado granodiorite pluton. Compare to figure 24. Explanation of municipality abbreviations can be found in appendix 1. (km, kilometer) 


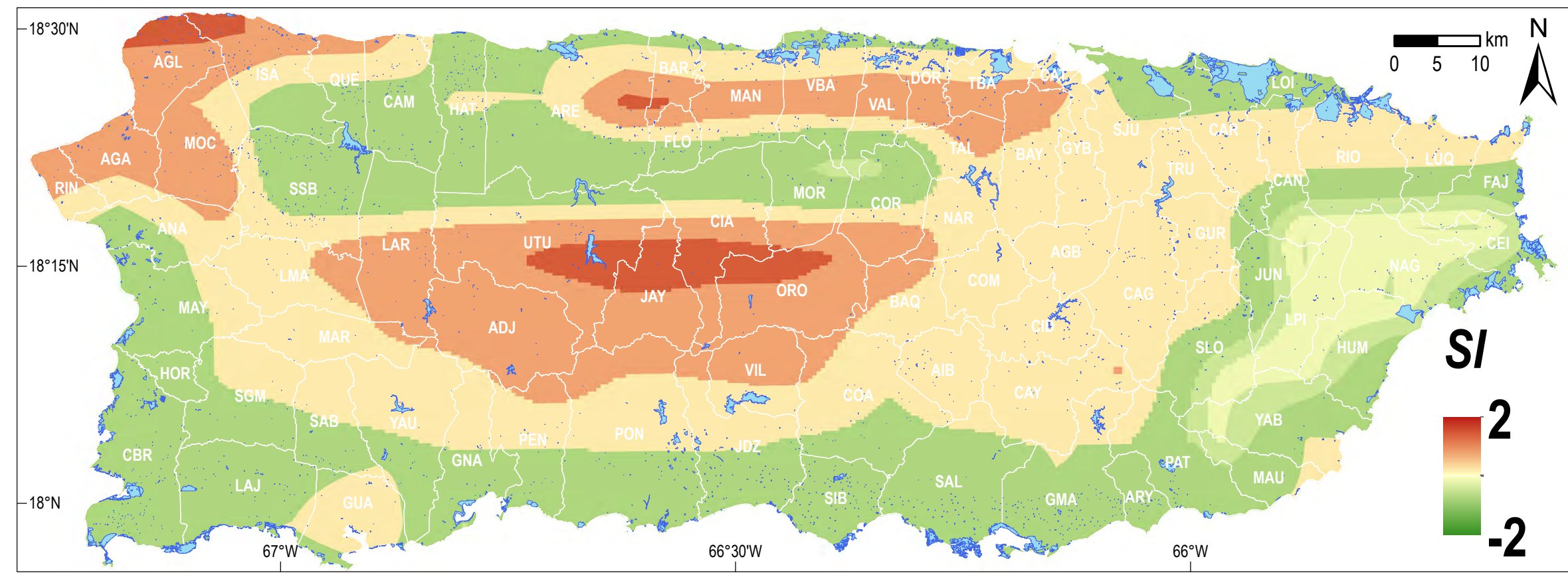

Figure 35. Results from Susceptibility Index (S/) analysis of Soil Moisture Active Passive data. The areas of highest root zone soil moisture estimated for 21 September 2017 correlate best with landslide sites. The $S /$ values for SMAP values were subtracted from the final model output as shown in equation 4 . This technique was used to minimize the effect of using one single-event inventory for a comprehensive susceptibility model. Compare to figure 26. Explanation of municipality abbreviations can be found in appendix 1 . ( $\mathrm{km}$, kilometer) 


\section{Map Performance}

Convention and experience indicate that landslide susceptibility maps are best understood when susceptibility is classified into several groups. Rankings of Low, Moderate, High, Very High, and Extremely High landslide susceptibility were assigned after binning the $S I A_{m}$ raster data into 100 equal-area quantiles. The categorization scheme is shown in table 5. The lower 40 percent of pixel values islandwide are considered representative of areas of low susceptibility. The 40th-70th percentile range corresponds to zones of moderate susceptibility. The 70th-90th percentile range is classified as having high susceptibility. The highest 10-1 percent of pixel values are classified as having very high vulnerability and the highest 1 percent are classified as having extremely high potential for failure. The ranking scheme was scrutinized in detail throughout the island at known sites and is consistent with the authors' field experience. The final map is provided as plate 1.

The final SIA and SIA model values were calculated using only 75 percent of the landslide inventory. The remaining 25 percent of the sites were used to independently test the validity of the model. The data were used to generate ROC plots to calculate area under curve (AUC) values, which are commonly used to evaluate slope hazard modeling (for example, Lepore and others, 2012; Xu and others, 2012; Li and others, 2016; Regmi and Poudel, 2016). The ROC plots were generated at increments of 5 for the full range ( -50 to 20 ) of SIA/SIA ${ }_{m}$ values. The true positive rate for a given boundary of SIA/SIA ${ }_{m}$ values was the number of landslides with $S I A / S I A_{m}$ values greater than any given increment (true positives) divided by the total number of landslides. The false positive rate for a given increment of $S I A / S I A_{m}$ values was the total number of pixels in the $S I A / S I A_{m}$ raster from which the number of landslides (true positives) and the number of pixels with values lower than the boundary were subtracted, and this difference was divided by the total number of pixels in the $S I A / S I A_{m}$ raster. AUC values can vary from 0.5 to 1.0 and quantify the false versus true predictions from a model. A value of 1.0 indicates perfect model performance and a value of 0.5 corresponds to a model that is equivalent to random prediction (Fawcett, 2006). The AUC value for SIA and SIA $A_{m}$ were compared to the AUC for the slope factor alone (fig. 36). Analysis of slope alone yields an AUC value of 0.83. The AUC for $S I A$ and $S I A_{m}$ are higher at 0.88 and 0.87 , respectively. The AUC of the composite $S I$ of all nonslope and non-SMAP factors (figs. 36 and 37 ) is 0.94 . This verification indicates that the model is both statistically viable and provides an improved prediction versus a slope-only model. Slope represents almost 50 percent of the final model. The nonslope and non-SMAP factors also represent almost 50 percent of the final susceptibility model and considered together yield the highest AUC value of the analysis. A composite map of these seven factors (curvature, proximity to road surface, geologic terrane, mean annual precipitation, proximity to fluvial channel, land cover, and soil classification) shows the highest correlating zones to be in the western interior region (fig. 37). Even though it has a much higher AUC value (0.94), the nonslope composite SI model was not adopted as the preferred model because the importance of slope cannot be overlooked in any mass movement model (for example, Carson and Petley, 1970). The lower performance of the slope-only dataset indicated by its lowest AUC value is likely due to the abundance of very high slopes on the flanks of mogotes, sinkholes, zanjones, and gorges in the karst terrain that do not usually suffer the same weathering and mass wasting processes as the remainder of the island, and because of factors described previously that are captured by inclusion of nonslope and non-SMAP factors. The decrease in AUC from SIA to SIA $m$ shows that the incorporation of SMAP data in the model slightly decreases its performance against the Hurricane María event inventory, as expected. Incorporation of the SMAP factor in $S I A_{m}$ was intended to buffer the influence of site-specific conditions related to the single event used for developing the predictive map. SMAP data incorporation also permits evaluation of variable soil moisture from future events and its effect on landsliding, as described in the "Use and Limitations of the Landslide Susceptibility Map" section.

Table 5. Results from comparison of the susceptibility map to locations of landslides in the Hurricane María inventory.

[SI, Susceptibility Index; km², square kilometer; \%, percent; \#, number; —, not applicable]

\begin{tabular}{|c|c|c|c|c|c|c|c|}
\hline $\begin{array}{c}\text { Susceptibility } \\
\text { ranking }\end{array}$ & $\begin{array}{c}\text { Approximate } S I \\
\text { range }\end{array}$ & Percentile & Area $\left(\mathrm{km}^{2}\right)$ & Area (\%) & $\begin{array}{l}\text { Landslides in } \\
\text { category (\#) }\end{array}$ & $\begin{array}{l}\text { Landslides in } \\
\text { category }(\%)^{1}\end{array}$ & $\begin{array}{c}\text { Density } \\
\text { (landslides/km²) }\end{array}$ \\
\hline Low & $-4.84-1.6$ & $0-40$ & 3481.2 & 40 & 843 & 1.2 & 0.2 \\
\hline Moderate & $-1.6--0.1$ & $40-70$ & 2609.3 & 30 & 7,108 & 10.0 & 2.7 \\
\hline High & $0.1-0.9$ & $70-90$ & 1740.5 & 20 & 20,988 & 29.4 & 12.1 \\
\hline Very High & $0.90-1.40$ & $90-99$ & 782.7 & 9 & 31,850 & 44.6 & 40.7 \\
\hline $\begin{array}{c}\text { Extremely } \\
\text { High }\end{array}$ & $.1 .40-1.97$ & 99-100 & 86.5 & 1 & 10,642 & 14.9 & 123.0 \\
\hline Total & - & - & $8,700.2$ & 100 & 71,431 & 100.1 & - \\
\hline
\end{tabular}

${ }^{1}$ Values calculated using the Hurricane María event inventory (Hughes and others, 2019). 
The model generated in this study was compared with the Lepore and others (2012) model and the raster model output was provided by C. Lepore (written commun., 2018). The pixel resolution of the Lepore and others' study (2012) was $30 \mathrm{~m}$, whereas our model resolution is $5 \mathrm{~m}$, which is advantageous because of its higher resolution and is possible because of the recent availability of a high-resolution lidar DEM dataset for the island. To quantitatively compare the models, Lepore and others' model output (2012) was grouped into 100 equal-area quantile classes in the same manner as our dataset. A raster output of the difference of quantile value from our model and their model is shown in figure 38. Within the 2 standard deviation $(\sigma)$ confidence interval, the similarity between the two models is only as good as \pm 37 quantiles. This metric indicates that the difference between the two model products is considerable. Table 6 shows a breakdown of which factors were used for each model's generation. Because elevation was not incorporated into our model, the Lepore and others' model (2012) tends to rank higher-elevation pixels with much higher susceptibility than our model. This effect is most evident in the high plateau area in the vicinity of the municipalities of Cidra, Cayey, Aibonito, and Barranquitas (fig. 38). In addition, the Lepore and others' methodology (2012) did not calculate $S I$ values by taking the natural log of the FR numbers. Their model output was a sum of FR values, which unevenly gives more weight to positive correlating factors than negative correlating factors. Many areas in figure 38, where our model ranks susceptibility higher than does Lepore and others (2012) result from higher slope SI values, which are almost onehalf of our model input but only make up 12 percent of Lepore and others' model input (2012).

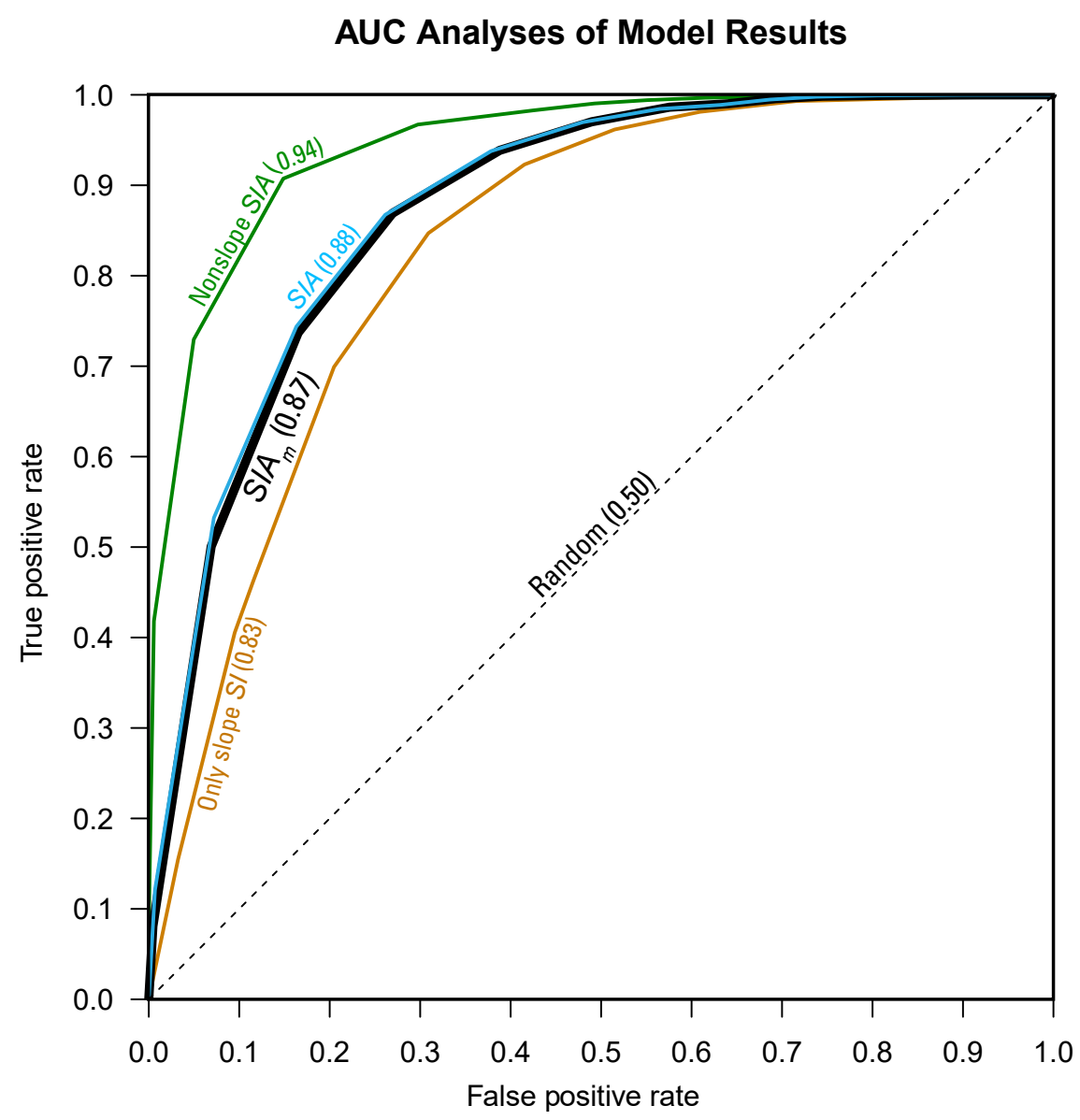

Figure 36. Receiver operating characteristic (ROC) area under curve (AUC) analyses for different combinations of data results. $S /$ indicates Susceptibility Index, $S I A$ indicates aggregate Susceptibility Index, and $S I A_{m}$ indicates aggregate Susceptibility Index modified by soil moisture. The final model chosen is the $S I A_{m}$ output. 


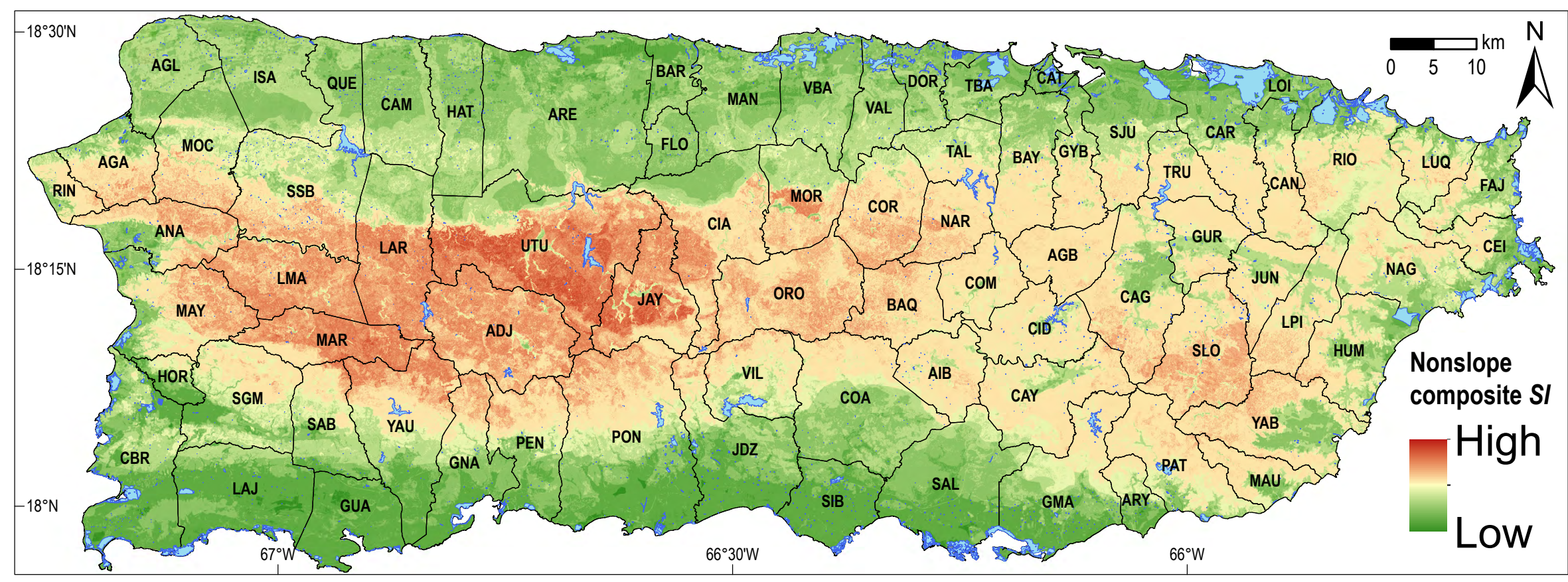

Figure 37. Composite Susceptibility Index ( $S /$ ) map of the seven nonslope and non-Soil Moisture Active Passive datasets used in the analysis. A neutral $S /$ score of 0 is shown as the neutral tan color. The combination of these factors yields a higher area under curve (AUC) value than slope alone (fig. 36). Explanation of municipality abbreviations can be found in appendix 1. (km, kilometer) 


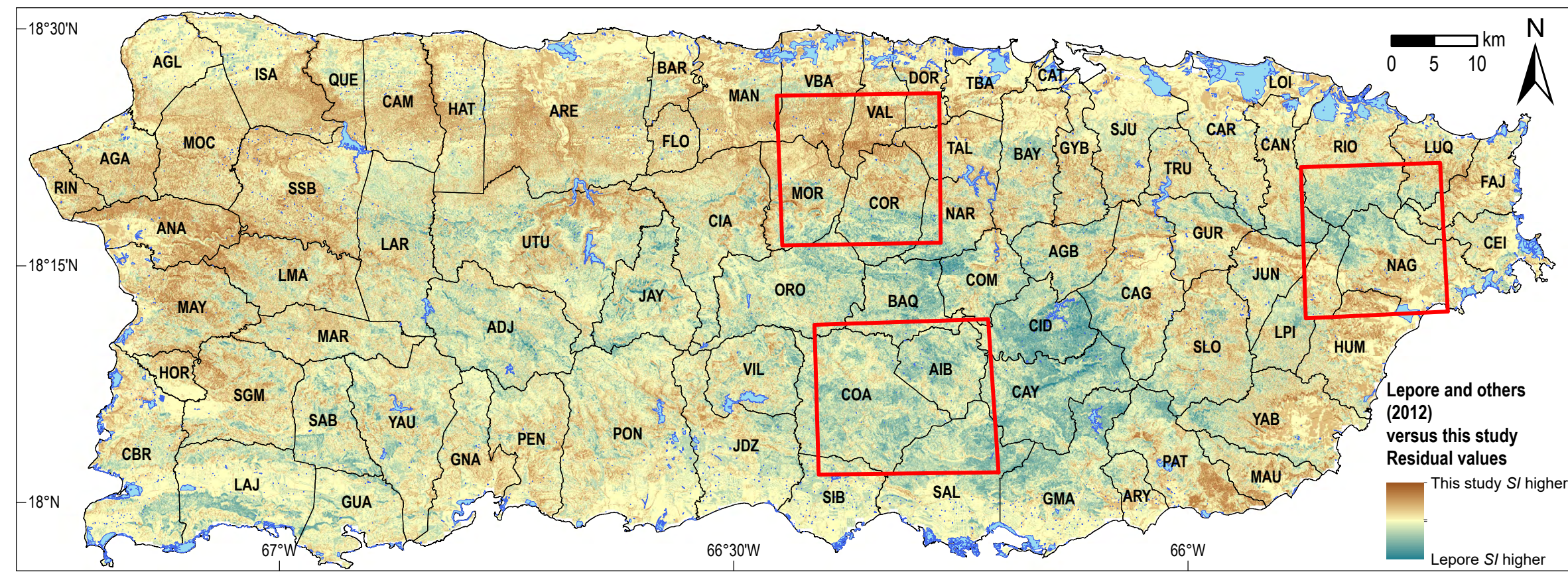

Figure 38. Residual values of Susceptibility Index (S/) model output from this study compared with the frequency ratio (FR) model output of Lepore and others (2012). Blue areas (nonwater) represent zones where the normalized Lepore model values are at least 10 percent higher than our normalized values. Orange pixels represent areas where our normalized values were at least 10 percent higher than those of Lepore and others (2012). Both models were standardized using quantiles in order to compare. The three red outlined areas show the extent of the landslide inventories used by Lepore and others (2012) to guide their whole-island susceptibility model. Explanation of municipality abbreviations can be found in appendix 1. ( $\mathrm{km}$, kilometer) 
Table 7 provides a summary of the density of landslides from the Hurricane María inventory (Hughes and others, 2019) for each of the susceptibility classification ranges of the susceptibility maps produced for the entire island (Monroe, 1979; Lepore and others, 2012; this study). The density values in the Low, Moderate, and High categories of both the current study and those of Lepore and others (2012) are strikingly similar; however, the current study model displays much higher density within the Very High susceptibility category and also includes an Extremely High category, which was well represented by the spatial density of landslides triggered by Hurricane María. Additionally, the model presented herein indicates Low susceptibility over an area more than twice as large as the corresponding area of Lepore and others (2012), and Very to Extremely High susceptibility over an area about one-half the size of the Lepore and others' Very High susceptibility area (2012).

Some specific notable landslide sites are presented here as examples of how the susceptibility model represents susceptibility at local scale:

- The Villa España Urbanization in the municipality of Bayamón was the site of a landslide on the southern flank of a mogote in August 2013 (fig. 39). Failure of the limestone material caused several houses to be condemned and eventually demolished. The analysis of the site in the current study shows that the area is classified as having High landslide susceptibility.
Table 6. Factors considered in quantitative Puerto Rico landslide susceptibility maps.

[x, factor considered in study, - , factor not considered in study]

\begin{tabular}{lcc}
\hline \multicolumn{1}{c}{ Factor } & This study & $\begin{array}{c}\text { Lepore and others } \\
\text { study (2012) }\end{array}$ \\
\hline Slope & $\mathrm{x}$ & $\mathrm{x}$ \\
Aspect & - & $\mathrm{x}$ \\
Elevation & - & $\mathrm{x}$ \\
Curvature & $\mathrm{x}$ & $\mathrm{x}$ \\
Distance from faults & - & $\mathrm{x}$ \\
Distance from roads & $\mathrm{x}$ & $\mathrm{x}$ \\
Distance from rivers & $\mathrm{x}$ & - \\
Geology & $\mathrm{x}$ & $\mathrm{x}$ \\
Soil & $\mathrm{x}$ & - \\
Land cover & $\mathrm{x}$ & $\mathrm{x}$ \\
Annual precipitation & $\mathrm{x}$ & - \\
Event soil moisture & $\mathrm{x}$ & - \\
\hline
\end{tabular}

- The Las Lomas Urbanization in the municipality of Ceiba suffered a landslide during October 2015 (fig. 40). The failure left several houses partially hanging over a new headscarp feature. This landslide was surveyed by the lidar campaign of 2015-2016 and the landslide susceptibility model produced by this study classifies the current site as having High to Very High landslide susceptibility. It is likely that the unfailed slope would have been classified as having High susceptibility, given the ranking of slopes adjacent to the failure.

- During the passing of Hurricane María in September 2017, a large landslide at km 56.2 of Highway PR-143 in the municipality of Barranquitas transitioned into a debris flow (figs. 8 and 41). The susceptibility model output of this study shows that the site had Very High to Extremely High landslide potential before the hurricane.

- In the urban center of the town of Utuado, a landslide caused by Hurricane María on a cut-bank between two houses resulted in the death of three elderly sisters (fig. 42; Irizarry Álvarez, 2017). The model output shows this site as having Very High to Extremely High landslide susceptibility prior to the hurricane.

- In December 2017, a cut slope at km 209.8 of Highway PR-2 in the municipality of Guayanilla failed and caused the road to be closed temporarily and traffic was diverted for many months (fig. 43). The model analysis in this study shows that this location registers as a site with Moderate to High landslide potential.

Table 7. Comparison of performance of Puerto Rico landslide susceptibility maps against the Hurricane María inventory.

[ $\mathrm{km}^{2}$, square kilometer; - , not applicable $]$

\begin{tabular}{lcccccc}
\hline \multicolumn{1}{c}{ Classification } & \multicolumn{5}{c}{ Density of Hurricane María landslides $\left(\mathbf{s i t e s} / \mathbf{k m}^{2}\right)^{\mathbf{1}}$} \\
\hline & \multicolumn{2}{c}{ Monroe (1979) } & \multicolumn{2}{c}{ Lepore and others (2012) } & \multicolumn{2}{c}{ This study } \\
\hline Lrea $\left(\mathbf{k m}^{2}\right)$ & Density & Area $\left(\mathbf{k m}^{2}\right)$ & Density & Area $\left(\mathbf{k m}^{2}\right)$ & Density \\
\hline Moderate & 5,051 & 0.3 & 1,617 & 0.1 & 3,481 & 0.2 \\
High & 3,472 & 19.7 & 3,561 & 2.6 & 2,609 & 2.7 \\
Very High & 272 & 4.0 & 1,649 & 12.8 & 1,741 & 12.1 \\
Extremely High & 78 & 6.8 & 1,764 & 23.3 & $783(2870)$ & $40.7(248.9)$ \\
\hline
\end{tabular}

${ }^{1}$ Hurricane María landslides from inventory of Hughes and others (2019).

${ }^{2}$ This is the value of the combination of the Very High and Extremely High classifications from the current study. 

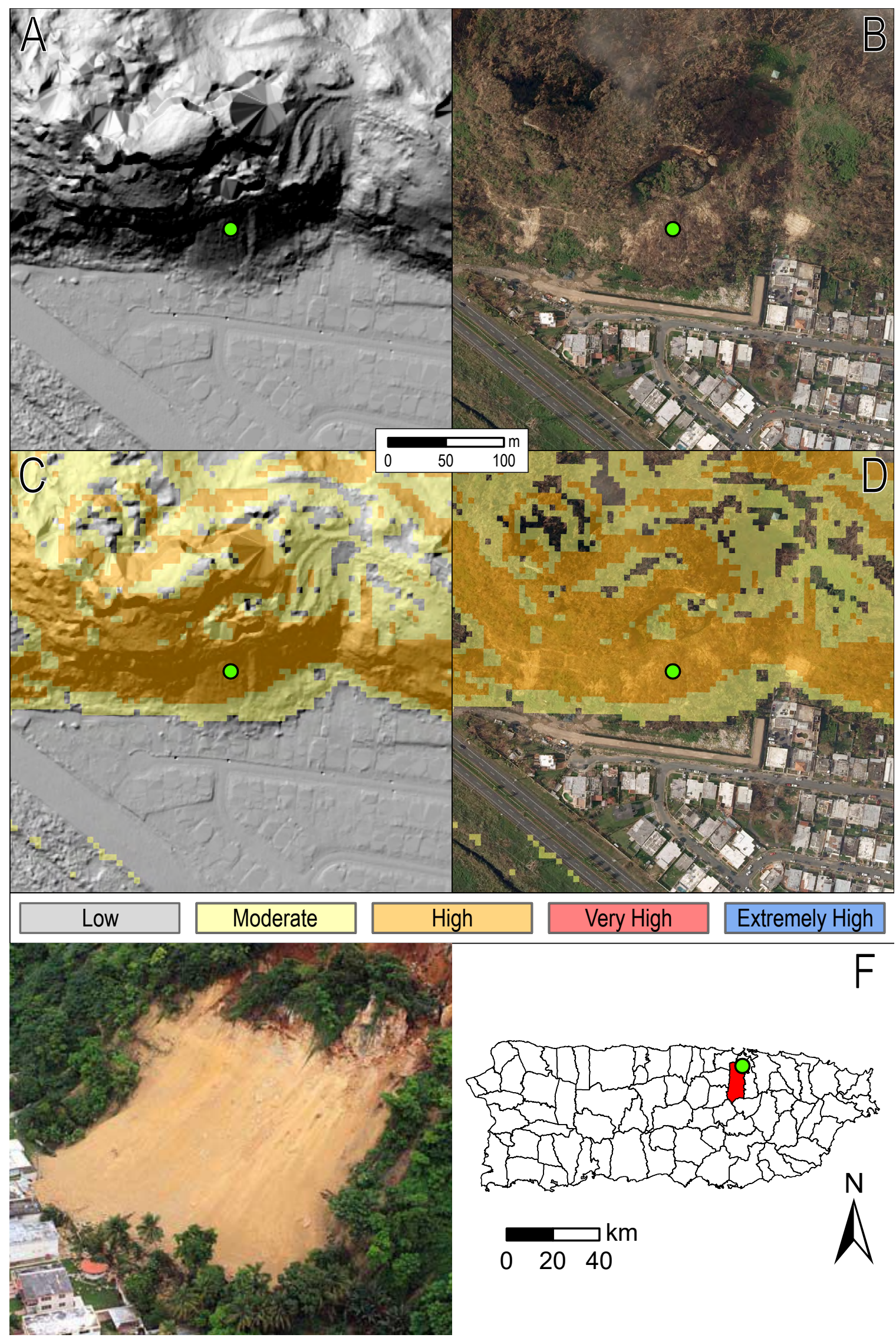
Figure 39 (previous page). Example of the Susceptibility Index model output for the Santa Ana mogote landslide at the Villa España Urbanization in the municipality of Bayamón, Puerto Rico. This site $(18.405,-66.144)$ failed on 20 August 2013. Panes A-D show the same extent. The green marker is presented in the center of each image and does not necessarily correspond to any landslide feature. $A$, Hillshade raster of the 2016 lidar survey data. B, Aerial view of the same location. The imagery was acquired on 80 ctober 2017 and shows the presence of a mitigation berm that was constructed at the site after the demolition of several houses. $C$, The final susceptibility map dataset overlayed on the hillshade raster. The site is classified as having High landslide susceptibility. $D$, The final susceptibility map dataset overlayed on the aerial imagery. $E$, An oblique aerial photograph of the site in 2013, shortly after the failure (Vazquez Torres, 2013). F, Location map of the area with the municipality of Bayamón highlighted in red, and the location of the Villa España site denoted by the green marker. (m, meter; km, kilometer) 

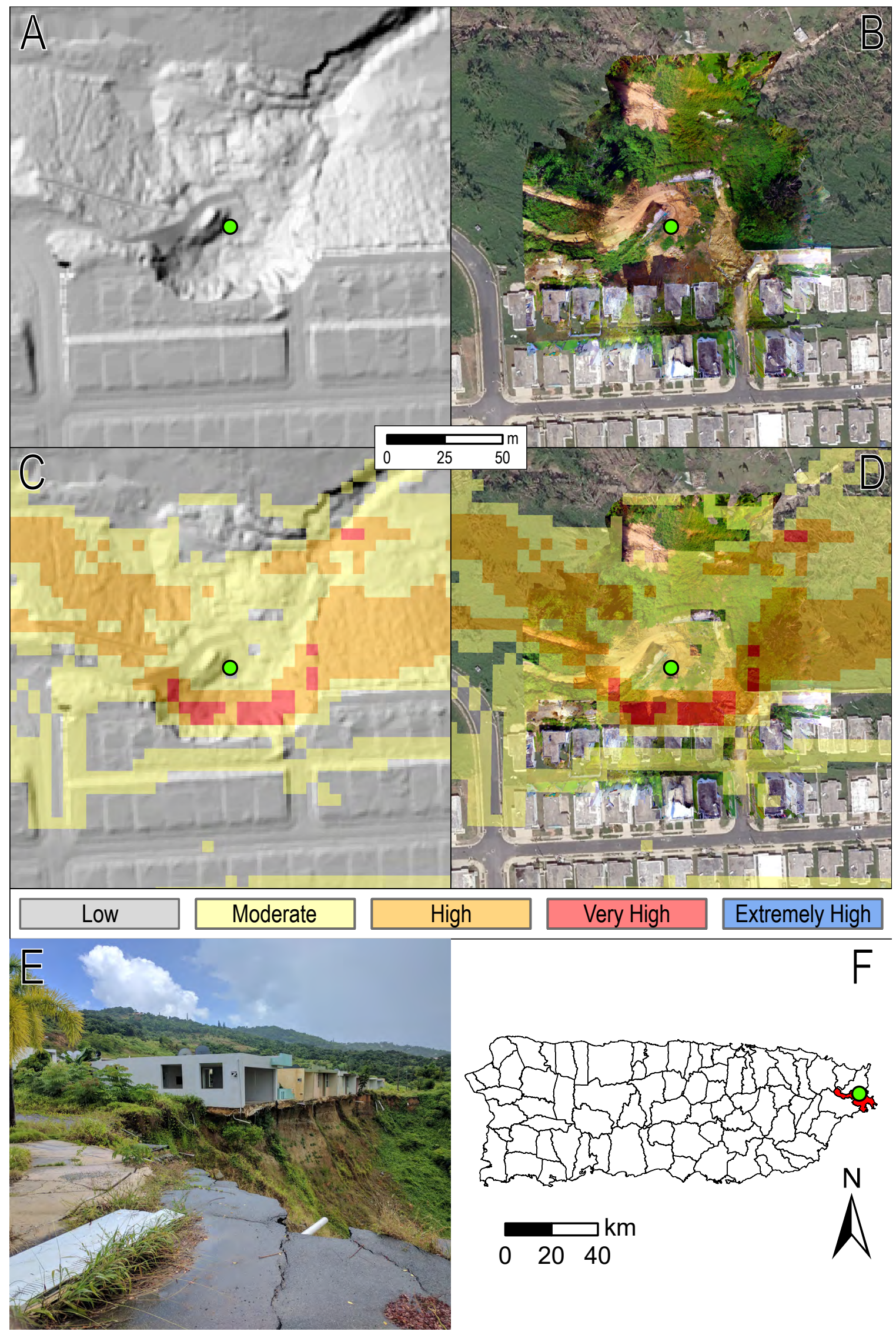
Figure 40 (previous page). Example of the Susceptibility Index model output for the Las Lomas Urbanization failure $(18.2708,-65.6615)$ in the municipality of Ceiba, Puerto Rico. Panes A-D show the same extent. The green marker is presented as the center of the area and does not necessarily correspond to any landslide feature. A, Hillshade raster of the 2016 lidar survey data. The scar where fill material that collapsed on 40 ctober 2015 and undermined several houses is visible. $B$, Aerial view of the same location. The imagery in the center is from a drone survey on 5 February 2017 by K.S. Hughes, and the outer imagery is from Federal Emergency Management Agency imagery of 27 0ctober 2017. C, The final susceptibility map dataset overlayed on the hillshade raster. The headscarp left behind by the 2015 failure registers as a zone of Very High landslide susceptibility, and the adjacent, unfailed slopes register as High susceptibility; it is likely that this High susceptibility zone would have extended across the landslide site prior to its occurrence. D, The final susceptibility map dataset overlayed on the aerial imagery. E, A photograph taken by K.S. Hughes of the headscarp on 17 June 2017. F, Location map of the area with the municipality of Ceiba is highlighted in red and the location of the Las Lomas site is denoted by the green marker. (m, meter; km, kilometer) 

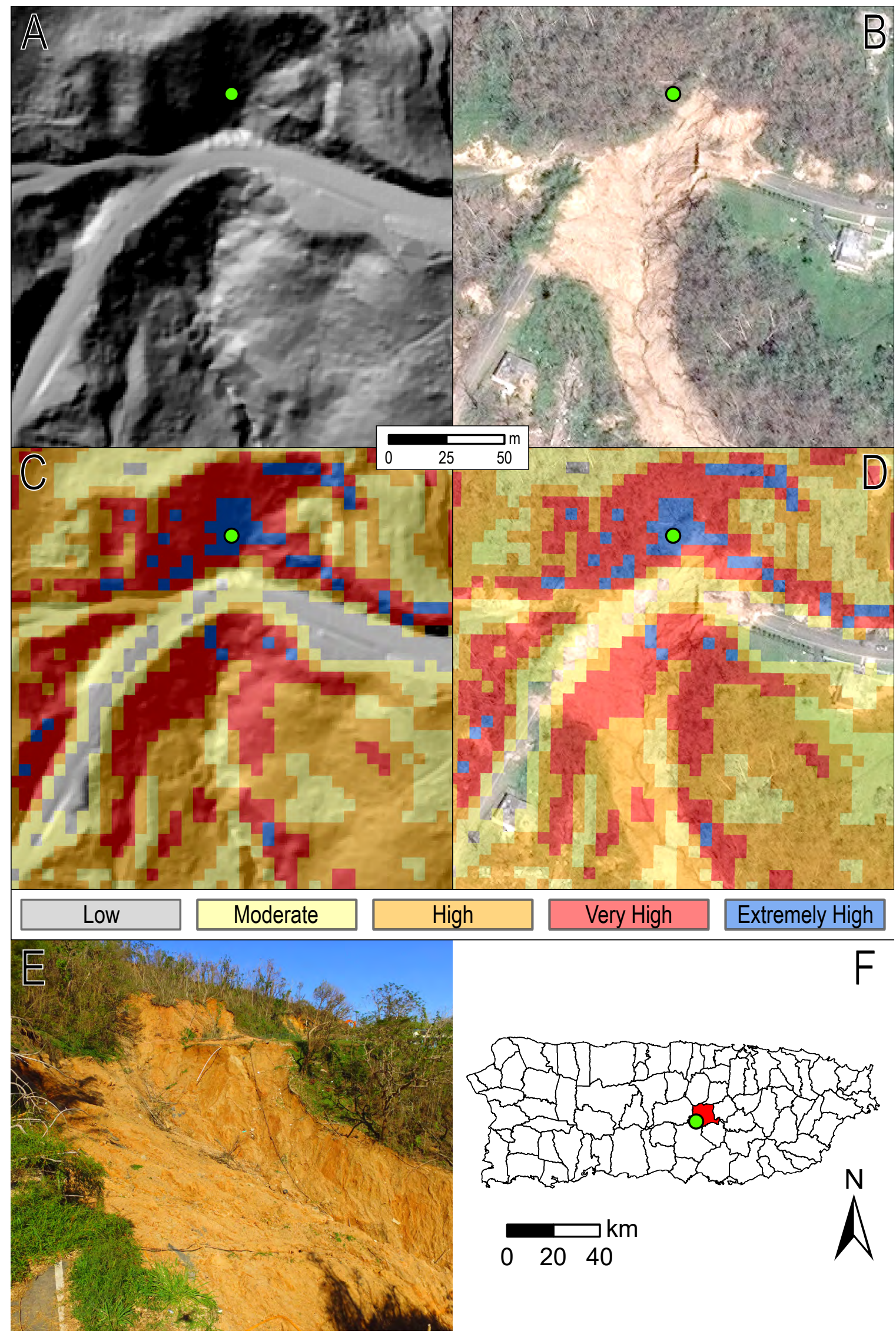
Figure 41 (previous page). Example of the Susceptibility Index model output for the PR-143 kilometer 56.2 landslide site in the municipality of Barranquitas, Puerto Rico. This location (18.176, -66.338) failed during Hurricane María (20 September 2017). Panes A-D show the same extent. The green marker is presented as the same location in each image and does not necessarily correspond to any landslide feature. $A$, Hillshade raster of the 2016 lidar survey data. The site has likely experienced previous landslide events. $B$, Aerial view of the same location. The imagery is a mosaic of photos that were acquired via aerial drone on 2 March 2018 by K.S. Hughes. $C$, The final susceptibility map dataset overlayed on the hillshade raster. The site is classified as having Very High to Extremely High landslide susceptibility. $D$, The final susceptibility map dataset overlayed on the satellite imagery. $E$, A photograph taken by K.S. Hughes looking east across the headscarp on 1 November 2017. The white pipe in the upper center of the image was about 80 meters away from the photographer. F, Location map of the area with the municipality of Barranquitas is highlighted in red and the location of the PR-143 kilometer 56.2 site is denoted by the green marker. This site is also shown in figure 8. (m, meter; km, kilometer) 


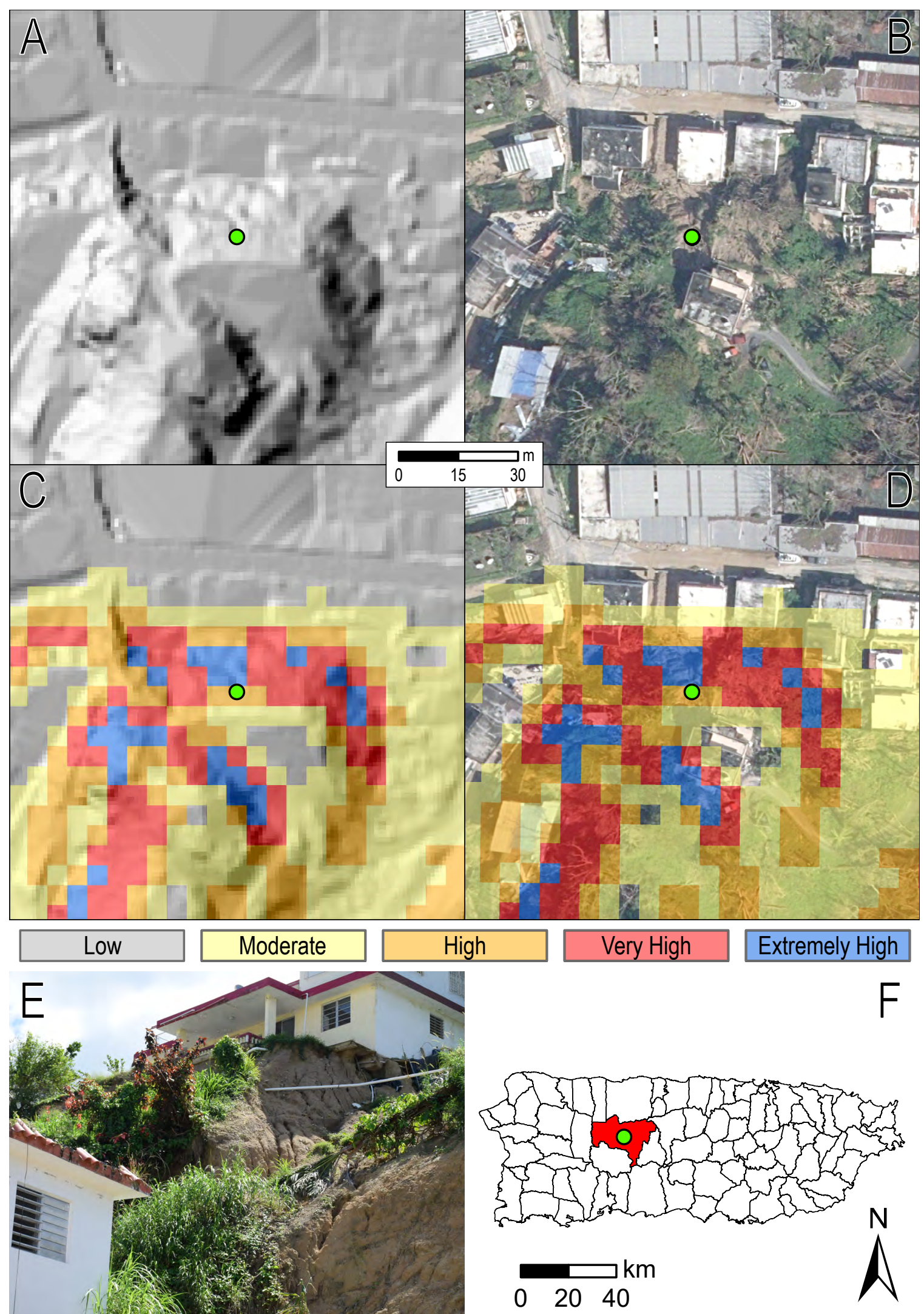


Figure 42 (previous page). Example of the Susceptibility Index model output for a landslide in the urban center of Utuado, Puerto Rico, caused by Hurricane María on 20 September 2017. This site $(18.264,-66.698)$ resulted in the death of three residents when the cut bank behind their house mobilized and filled part of the lower level of the structure. Panes A-D show the same extent. The green marker is presented in the center of each image and does not necessarily correspond to any landslide feature. $A$, Hillshade raster of the 2016 lidar survey data. $B$, Aerial view of the same location. The imagery was acquired on 120 ctober 2017 and shows the scar of the landslide between the upper (south) and lower (north) houses. $C$, The final susceptibility map dataset overlayed on the hillshade raster. This site is classified as having Very High to Extremely High failure susceptibility. $D$, The final susceptibility map dataset overlayed on the aerial imagery. E, Photograph of the site on 2 November 2017 by Dr. Daniel Pradel (photo used with permission). $F$, Location map of the area with the municipality of Utuado is highlighted in red, and the location of the landslide is denoted by the green marker. ( $\mathrm{m}$, meter; $\mathrm{km}$, kilometer) 

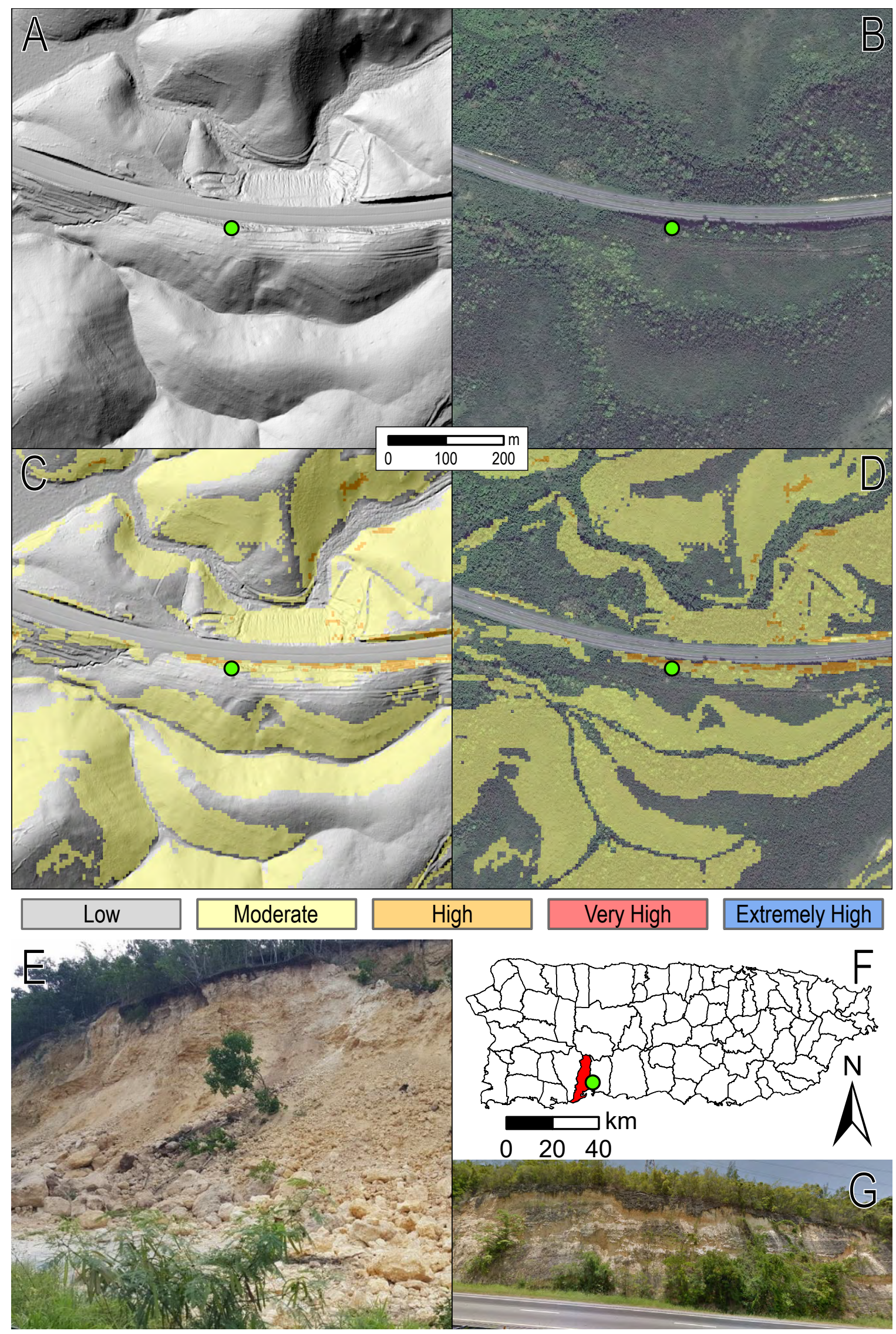
Figure 43 (previous page). Example of the Susceptibility Index model output for a landslide at kilometer 209.3 along Highway PR-2 in the municipality of Guayanilla, Puerto Rico, that occurred on 6 December 2017. This site $(18.0112,-66.7569)$ resulted in the temporary closure of the regional highway, and the headscarp was very near a transmission tower of the electrical distribution system. Panes $\mathrm{A}-\mathrm{D}$ show the same extent. The green marker is presented in the center of each image and does not necessarily correspond to any landslide feature. $A$, Hillshade raster of the 2016 lidar survey data. $B$, Aerial view of the same location. The imagery was acquired between October and December of 2017 by DigitalGlobe. $C$, The final susceptibility map dataset overlayed on the hillshade raster. This site is classified as having Moderate to High susceptibility to landslides. $D$, The final susceptibility map dataset overlayed on the aerial imagery. E, Photograph of the site on 6 December 2017 (Metro Puerto Rico, 2017). F, Location map of the area with the municipality of Guayanilla is highlighted in red, and the location of the landslide is denoted by the green marker. $G$, Image from Google Street View of the future failure site from May 2016. (m, meter; $\mathrm{km}$, kilometer) 


\section{Use and Limitations of the Landslide Susceptibility Map}

Plate 1 and geographic information system (GIS) files that accompany this report (Hughes and Schulz, 2020) depict estimated relative susceptibility to landslide occurrence during or soon after intense rainfall, such as that produced during tropical storms including hurricanes. The data are intended to illustrate relative potential landslide hazard to help guide site-specific landslide susceptibility assessments, and plan for future development and future widespread landslide events. For example, locations with higher landslide susceptibility could (1) be excluded from future development; (2) require slope-stability studies prior to development, and grading, foundation, and drainage design and construction that considers potential slope instability; (3) be targeted for evaluation and mitigation of potentially adverse conditions; (4) be monitored for signs of incipient landsliding, such as cracks in roadways and structures, leaning utility poles and trees, and broken water or sewer lines; and (or) (5) be considered for evacuation prior to forecasted landslide-inducing rainfall events and for emergency response activities after such rainfall. The map is not a substitute for site-specific, slope-stability investigations by licensed geologists and engineers. Additionally, many landslides in Puerto Rico move far from the locations where they originate and can destroy structures and injure and kill people as they move downslope; the map does not depict this significant hazard resulting from mobile landslides. Finally, locations of landslides triggered by earthquakes or prolonged, relatively low-intensity rainfall may significantly differ from High, Very High, and Extremely High susceptibility locations shown on the map.

For best use during emergency response to specific rainfall events, the map should be evaluated alongside event-specific rainfall conditions, with landslides being more likely where higher amounts of rainfall occur in locations with higher landslide susceptibility. As described herein, root-zone soil moisture estimated by the NASA SMAP mission correlated well with landslide locations during Hurricane María, and professionals may utilize event-specific soil moisture for more quantitative assessment of potential locations of landslides that result from future rainfall. Such use requires expertise in GIS data manipulation. Interested professionals may obtain root-zone soil moisture data from the NASA SMAP mission (https://smap.jpl.nasa.gov/, last accessed 26 December 2019), ensure that the data projection matches that of the SI_raster_for_SMAP files available with this report, reclassify the NASA SMAP data to the appropriate $S I$ values provided in table 3, sum the SI_raster_for_SMAP and reclassified NASA SMAP data, and reclassify the sum by area percentile to obtain susceptibility rankings as provided in table 5 .

Most landslides in Puerto Rico triggered by intense rainfall are shallow (to several meters deep) and occur in unconsolidated material (soil and saprolite) overlying rock (for example, Jibson, 1989; Larsen and Torres Sanchez, 1992; Bessette-Kirton and others, 2019). These are the types of landslides most well represented by the landslide susceptibility map because the map was produced using an inventory of landslides triggered by Hurricane María (Hughes and others, 2019) and most of those landslides were shallow. Hurricane María also triggered landslides in rock and some reached depths of approximately $30 \mathrm{~m}$ (Bessette-Kirton and others, 2019), so the map also depicts susceptibility to deeper landslides and those in rock. The tragic landslide that occurred at Mameyes in Ponce municipality during 1985, which killed more than 129 people (Silva-Tulla, 1986), is an example of a type of landslide that is likely poorly represented by the susceptibility map. Additionally, many landslides worldwide are triggered by human activities, such as hillslope grading and redirection of drainage. Local activities such as these cannot be accounted for on the map.

Common to nearly all modeling efforts, accuracy of the landslide susceptibility map relies upon accuracy and completeness of the input data utilized for its development. Among others, we expect that the following omissions and conditions detract from accuracy of the map: (1) variability within given geological terranes of bedrock strength and hydrologic properties, discontinuity orientation, and condition; (2) variability within given soil types of soil strength and hydrologic properties; (3) consideration of only part of the road network, including omission of most undocumented farm roads, paths, and trails; and (4) use of a 2015-2016 topographic model that predates landslides triggered by Hurricane María and other topographic changes.

\section{Conclusion}

Landslides are a common occurrence in Puerto Rico, with nearly two widespread landslide events occurring annually during recent decades. The high susceptibility of landslides in Puerto Rico primarily results from the island's topographic disequilibrium, rapid bedrock weathering, high-frequency intense rainfall events, and intense agrarian and urbanization practices during the past centuries. The high population density of Puerto Rico places many of its citizens and much of its infrastructure at risk to landslide events, as was well illustrated by the more than 70,000 landslides triggered during September 2017 by Hurricane María.

A digital inventory of those landslides was used alongside geospatial data that included land surface slope and curvature calculated from a light detection and ranging digital elevation model, mean annual precipitation, proximity to roadways and streams, geologic terrane, soil classification, land cover, and estimated soil moisture immediately following Hurricane María to develop a map depicting relative susceptibility to landslide occurrence during and following future intense rainfall events. The frequency-ratio statistical approach was utilized to identify relationships between landslide location and the geospatial data attributes and to develop the map. Results from analysis of soil moisture were used in an attempt to generalize the map by removing 
the effects of variable soil moisture resulting from Hurricane María. Analysis using 25 percent of the landslide inventory sites that were not utilized for development of the map demonstrates that the map is statistically viable. Results of the analyses of these specific factors for Puerto Rico may potentially be adaptable for other tropical regions with comparable climate, topography, and geology.

The final map product depicts the susceptibility to landslide occurrence as Low (40 percent of the main island), Moderate (30 percent), High (20 percent), Very High (9 percent), and Extremely High (1 percent). Areas where landslides might travel after they occur are not shown on the map, although hazards may be extremely high in these areas. The map is intended to serve as a general guide for development planning, assessments of potential landslides and mitigation strategies across large areas, and emergency planning. The map is not a replacement for site-specific, slope-stability evaluations that should be performed by licensed geologists and engineers.

\section{References Cited}

Acevido, G., 1982, Soil survey of Arecibo area of northern Puerto Rico: U.S. Department of Agriculture Soil Conservation Service, 169 p. [Also available at https://www.nrcs.usda.gov/Internet/FSE_MANUSCRIPTS/puerto_rico/PR682/0/Arecibo.pdf.]

Bawiec, W.J., 1998, Geologic terranes of Puerto Rico, in Bawiec, W.J., ed., Geology, geochemistry, geophysics, mineral occurrences and mineral resource assessment for the Commonwealth of Puerto Rico: U.S. Geological Survey Open-File Report 98-038, p. 59-71, accessed February 28, 2020, at https://pubs.usgs.gov/of/1998/of98-038/.

Bayouth García, D., Rodríguez Feliciano, C.A., and Hughes, K.S., 2018, Event-specific and annual precipitation controls on mass wasting sites in Puerto Rico after the passage of Hurricane María, in Geological Society of America Annual Meeting, Indianapolis, Ind., 2018, Abstracts with Programs: Boulder, Colo., Geological Society of America, Paper 171-12, v. 50, no. 6, accessed February 28, 2020, at https://doi.org/10.1130/abs/2018AM-320596.

Berryhill, H.L., Jr., 1965, Geology of the Ciales quadrangle, Puerto Rico: U.S. Geological Survey Bulletin 1184, 116 p., 3 pls. [Also available at https://doi.org/10.3133/b1184.]

Bessette-Kirton, E.K., Cerovski-Darriau, C., Schulz, W.H., Coe, J.A., Kean, J.W., Godt, J.W., Thomas, M.A., and Hughes, K.S., 2019, Landslides triggered by Hurricane María — Assessment of an extreme event in Puerto Rico: GSA Today, v. 29, no. 6, p. 4-10. [Also available at https://www.geosociety.org/gsatoday/science/G383A/article.htm.]

Boccheciamp, R.A., 1977, Soil survey of the Humacao area of eastern Puerto Rico: U.S. Department of Agriculture Soil Conservation Service, 103 p. [Also available at https://www.nrcs.usda.gov/Internet/FSE_MANUSCRIPTS/puerto_rico/PR689/0/Humacao.pdf.]

Boccheciamp, R.A., 1978, Soil survey of San Juan area of Puerto Rico: U.S. Department of Agriculture Soil Conservation Service, 141 p. [Also available at https://www.nrcs.usda.gov/Internet/FSE_MANUSCRIPTS/puerto_rico/PR686/0/San_Juan.pdf.]

Brabb, E.E., 1984, Innovative approaches to landslide hazard and risk mapping, in Fourth International Symposium on Landslides, Toronto, Ontario, Canada, 1984, Proceedings: Toronto, Canadian Geotechnical Society, v. 1, p. 307-324.

Briggs, R.P., 1965, Geologic map of the Barceloneta quadrangle, Puerto Rico: U.S. Geological Survey Miscellaneous Geologic Investigations Map I-421, scale 1:20,000. [Also available at https://doi.org/10.3133/i421.]

Briggs, R.P., 1968, Geologic map of the Arecibo quadrangle Puerto Rico: U.S. Geological Survey Miscellaneous Geologic Investigations Map I-551, scale 1:20,000. [Also available at https://doi.org/10.3133/i551.]

Brocard, G.Y., Willenbring, J.K., Scatena, F.N., and Johnson, A.H., 2015, Effects of a tectonically-triggered wave of incision on riverine exports and soil mineralogy in the Luquillo Mountains of Puerto Rico: Applied Geochemistry, v. 63, p. 586-598. [Also available at https://doi.org/10.1016/j.apgeochem.2015.04.001.]

Campbell, R.H., Herd, D.G., and Alonso, R.M., 1985, Preliminary response activities and recommendations of the USGS Landslide Hazard Research Team to the Puerto Rico landslide disaster of October 7, 1985: U.S. Geological Survey Open-File Report 85-719, 13 p. [Also available at https://doi.org/10.3133/ofr85719.]

Carson, M.A., and Petley, D.J., 1970, The existence of threshold hillslopes in the denudation of the landscape: Translations of the Institute of British Geographers, v. 49, p. 71-95. [Also available at http://doi.org/10.2307/621642.] 
Carter, O.R., 1965, Soil survey of the Lajas Valley area, Puerto Rico: U.S. Department of Agriculture Soil Conservation Service, Series 1961, no. 23, 170 p. [Also available at https://www.nrcs.usda.gov/Internet/FSE_MANUSCRIPTS/puerto_rico/ lajasPR1965/Lajas.pdf.]

Chalkias, C., Kalogirou, S., and Ferentinou, M., 2014, Landslide susceptibility, Peloponnese Peninsula in south Greece: Journal of Maps, v. 10, no. 2, p. 211-222. [Also available at https://doi.org/10.1080/17445647.2014.884022.]

Civil Air Patrol, 2017, CAP imagery-Hurricane María: Civil Air Patrol web page, accessed January 13, 2020, at https:/www.arcgis.com/home/webmap/viewer.html?webmap=3218d1cb022d4534be0c7d6833c0adf1.

Deere, D.U., Jimenez, P., and Hernandez, D., 1989, Complex landslides at plateau margins with an example from Puerto Rico, chap. 19 of Cording, E.J., Hall, W.J., Haltiwanger, J.D., Hendron, A.J., Jr., and Mesri, G., eds., The art and science of geotechnical engineering - At the dawn of the twenty-first century-A volume honoring Ralph B. Peck: Englewood Cliffs, N.J., Prentice-Hall, p. 349-366.

Dietz, J.L., 1986, Economic history of Puerto Rico-Institutional change and capitalist development: Princeton, N.J., Princeton University Press, $337 \mathrm{p}$.

Dorsey, C.W., Mesmer, L., and Caine, T.A., 1903, Soil survey from Arecibo to Ponce, Porto Rico: U.S. Department of Agriculture Bureau of Soils Field Operation 1902 Report no. 4, p. 793-839. [Also available at https:/www.nrcs.usda.gov/Internet/ FSE_MANUSCRIPTS/puerto_rico/areciboponcePR1902/areciboponcePR1902.pdf.]

Doser, D.I., Rodríguez, C.M., and Flores, C., 2005, Historical earthquakes of the Puerto Rico-Virgin Islands region (1915-1963), in Mann, P., ed., Active tectonics and seismic hazards of Puerto Rico, the Virgin Islands, and offshore areas: Geological Society of America Special Paper 385, p. 103-114. [Also available at https://doi.org/10.1130/0-8137-2385-X.103.]

Fawcett., T., 2006, An introduction to ROC analysis: Pattern Recognition Letters, v. 27, no. 8, p. 861-874. [Also available at https://doi.org/10.1016/j.patrec.2005.10.010.]

Fick, S.E., and Hijmans, R.J., 2017, WorldClim 2-New 1-km spatial resolution climate surfaces for global land areas: International Journal of Climatology, v. 37, no. 12, p. 4302-4315. [Also available at https://doi.org/10.1002/joc.5086.]

García López, X.A., 2018, Lidar and RTK GPS SfM monitoring of the PR-9 landslide in Ponce, Puerto Rico (2016-2018): University of Puerto Rico at Mayagüez, Undergraduate research thesis, 23 p.

Gierbolini, R.E., 1975, Soil survey of Mayaguez area of western Puerto Rico: U.S. Department of Agriculture Soil Conservation Service, 296 p. [Also available at https://www.nrcs.usda.gov/Internet/FSE_MANUSCRIPTS/puerto_rico/PR684/0/Mayaguez.pdf.]

Gierbolini, R.E., 1979, Soil survey of the Ponce area of southern Puerto Rico: U.S. Department of Agriculture Soil Conservation Service, 80 p. [Also available at https://www.nrcs.usda.gov/Internet/FSE_MANUSCRIPTS/puerto_rico/PR688/0/Ponce.pdf.]

Gould, W.A., Alarcón, C., Fevold, B., Jiménez, M.E., Martinuzzi, S., Potts, G., Quiñones, M., Solórzano, M., and Ventosa, E., 2008, Puerto Rico 2000 GAP Land Cover: U.S. Geological Survey web page, accessed September 12, 2019 , at https://www.sciencebase.gov/catalog/item/560c3b2de4b058f706e5411e.

Grau, H.R., Aide, T.M., Zimmerman, J.K., Thomlinson, J.R., Helmer, E., and Zou, X., 2003, The ecological consequences of socioeconomic and land-use changes in postagriculture Puerto Rico: BioScience, v. 53, no. 12, p. 1159-1168. [Also available at https://doi.org/10.1641/0006-3568(2003)053[1159:TECOSA]2.0.CO;2.]

Grindlay, N.R., Abrams, L.J., Del Greco, L., and Mann, P., 2005, Toward an integrated understanding of Holocene fault activity in western Puerto Rico - Constraints from high-resolution seismic and sidescan sonar data, in Mann, P., ed., Active tectonics and seismic hazards of Puerto Rico, the Virgin Islands, and offshore areas: Geological Society of America Special Paper 385, p. 139-160. [Also available at https://doi.org/10.1130/0-8137-2385-X.139.]

He, Y., and Beighley, R.E., 2008, GIS-based regional landslide susceptibility mapping-A case study in southern California: Earth Surface Processes and Landforms, v. 33, no. 3, p. 380-393. [Also available at https://doi.org/10.1002/esp.1562.]

Huffaker, L., 2002, Soil survey of Caribbean National Forest and Luquillo Experimental Forest, Commonwealth of Puerto Rico: U.S. Department of Agriculture Natural Resources Conservation Service, 181 p. [Also available at https://www.nrcs.usda.gov/ Internet/FSE_MANUSCRIPTS/puerto_rico/caribbeanNF_PR2002/CNF.pdf.] 
Hughes, K.S., Bayouth García, D., Martínez Milian, G.O., Schulz, W.H., and Baum, R.L., 2019, Map of slope-failure locations in Puerto Rico after Hurricane María: U.S. Geological Survey data release, accessed September 12, 2019, at https://doi.org/10.5066/ P9BVMD74.

Hughes, K.S., and Morales Vélez, A.C., 2017, Characterization of landslide sites in Puerto Rico after Hurricanes Irma and María, in American Geophysical Union Fall Meeting 2017, New Orleans, La., 2017, Abstracts: American Geophysical Union, Abstract NH23E-2859.

Hughes, K.S., and Schulz, W.H., 2020, Results from frequency-ratio analyses of soil classification and land use related to landslide locations in Puerto Rico following Hurricane María: U.S. Geological Survey data release, https://www.sciencebase.gov/ catalog/item/5e2f53f5e4b0a79317d42330.

Irizarry Álvarez, F., 2017, Mueren tres hermanas por derrumbe en Utuado tras paso de María: Primera Hora, September 21, 2017, accessed September 12, 2019, at https://www.primerahora.com/noticias/puerto-rico/nota/ muerentreshermanasporderrumbeenutuadotraspasodeMaría -1246727/.

Jennings, L.N., Douglas, J., Treasure, E., and González, G., 2014, Climate change effects in El Yunque National Forest, Puerto Rico, and the Caribbean region: Asheville, N.C., U.S. Department of Agriculture Forest Service, Southern Research Station, General Technical Report SRS-193, 47 p. [Also available at https://www.fs.usda.gov/treesearch/pubs/45918.]

Jibson, R.W., 1986, Evaluation of landslide hazards resulting from the 5-8 October 1985 storm in Puerto Rico: U.S. Geological Survey Open-File Report 86-26, 40 p. [Also available at https://doi.org/10.3133/ofr8626.]

Jibson, R.W., 1987, Landslide hazards of Puerto Rico, in Hays, W.W., and Gori, P.L., eds., Proceedings of Conference XXXVI—A workshop on "Assessment of geologic hazards and risk in Puerto Rico": U.S. Geological Survey Open-File Report 87-008, p. 183-188. [Also available at https://pubs.usgs.gov/of/1987/0008/report.pdf.]

Jibson, R.W., 1989, Debris flows in southern Puerto Rico, in Schultz, A.P., and Jibson, R.W., eds., Landslide processes of the eastern United States and Puerto Rico: Geological Society of America Special Paper 236, p. 29-55. [Also available at https://doi.org/10.1130/SPE236-p29.]

Jolly, W.T., Lidiak, E.G., Dickin, A.P., and Wu, T., 1998a, Geochemical diversity of Mesozoic island arc tectonic blocks in eastern Puerto Rico, in Lidiak, E.G., and Larue, D.K., eds., Tectonics and geochemistry of the northeastern Caribbean: Geological Society of America Special Paper 322, p. 67-98. [Also available at https://doi.org/10.1130/0-8137-2322-1.67.]

Jolly, W.T., Lidiak, E.G., Schellekens, J.H., and Santos, H., 1998b, Volcanism, tectonics, and stratigraphic correlations in Puerto Rico, in Lidiak, E.G., and Larue, D.K., eds., Tectonics and geochemistry of the northeastern Caribbean: Geological Society of America Special Paper 322, p. 1-34. [Also available at https://doi.org/10.1130/0-8137-2322-1.1.]

Kamal, S.A., 2008, Development of a landslide hazard map for the island of Puerto Rico: Massachusetts Institute of Technology, M.S. thesis, 58 p. [Also available at http://hdl.handle.net/1721.1/43886.]

Keellings, D., and Hernández Ayala, J.J., 2019, Extreme rainfall associated with Hurricane María over Puerto Rico and its connections to climate variability and change: Geophysical Research Letters, v. 46, no. 5, p. 2964-2973. [Also available at https://doi.org/10.1029/2019GL082077.]

Knutson, T.R., McBride, J.L, Chan, J., Emanuel, K., Holland, G., Landsea, C., Held, I., Kossin, J.P., Srivastava, A.K., and Sugi, M., 2010, Tropical cyclones and climate change: Nature Geoscience, v. 3, p. 157-163. [Also available at https://doi.org/10.1038/ngeo779.]

Larsen, M.C., 2012, Landslides and sediment budgets in four watersheds in eastern Puerto Rico, chap. F of Murphy, S.F., and Stallard, R.F., eds., Water quality and landscape processes of four watersheds in eastern Puerto Rico: U.S. Geological Survey Professional Paper 1789, p. 153-178. [Also available at https://doi.org/10.3133/pp1789F.]

Larsen, M.C., and Parks, J.E., 1997, How wide is a road? The association of roads and mass-wasting in a forested montane environment: Earth Surface Processes and Landforms, v. 22, no. 9, p. 835-848. [Also available at https://doi.org/10.1002/ (SICI)1096-9837(199709)22:9\%3C835::AID-ESP782\%3E3.0.CO;2-C.]

Larsen, M.C., and Parks, J.E., 1998, Map showing landslide susceptibility in the Comerio municipality, Puerto Rico: U.S. Geological Survey Open-File Report 98-566, 1 map sheet, scale 1:20,000. [Also available at https://doi.org/10.3133/ofr98566.] 
Larsen, M.C., and Santiago Román, A., 2001, Mass wasting and sediment storage in a small montane watershed—An extreme case of anthropogenic disturbance in the humid tropics, in Dorava, J. M., Fitzpatrick, F., Palcsak, B.B., and Montgomery, D.R., eds., Geomorphic processes and riverine habitat: American Geophysical Union, Water Science and Application Series, v. 4, p. 119-138. [Also available at https://pdfs.semanticscholar.org/6c39/1b6cb4c6de01c1f0468851df37e84a0f2ced.pdf.]

Larsen, M.C., Santiago, M., Jibson, R., and Questell, E., 2004, Map showing susceptibility to rainfall-triggered landslides in the municipality of Ponce, Puerto Rico: U.S. Geological Survey Scientific Investigations Map I-2818, 1 pl., scale 1:30,000. [Also available at https://pubs.usgs.gov/sim/2005/2818/.]

Larsen, M.C., and Simon, A., 1990, Landslide processes in saprolitic soils of a tropical rain forest, Puerto Rico in Larue, D.K., and Draper, G., eds., Transactions of the 12th Caribbean Conference, August 7-11, 1989, St. Croix, V.I.: Miami Geological Society, p. 217-222.

Larsen, M.C., and Simon, A., 1993, A rainfall intensity-duration threshold for landslides in a humid-tropical environment, Puerto Rico: Geografiska Annaler, Series A-Physical Geography, v. 75, no. 1-2, p. 13-23.

Larsen, M.C., and Torres-Sanchez, A.J., 1992, Landslides triggered by Hurricane Hugo in eastern Puerto Rico, September 1989: Caribbean Journal of Science, v. 28, no. 3-4, p. 113-125.

Lee, S., and Pradhan, B., 2006, Probabilistic landslide hazards and risk mapping on Penang Island, Malaysia: Journal of Earth System Science, v. 115, no. 6, p. 661-672. [Also available at https://doi.org/10.1007/s12040-006-0004-0.]

Lee, S., Ryu, J.H., and Kim, I.S., 2007, Landslide susceptibility analysis and its verification using likelihood ratio, logistic regression, and artificial neural network models - Case study of Youngin, Korea: Landslides, v. 4, no. 4, p. 327-338. [Also available at https://doi.org/10.1007/s10346-007-0088-x.]

Lepore, C., Kamal, S.A., Shanahan, P., and Bras, R.L., 2012, Rainfall-induced landslide susceptibility zonation of Puerto Rico: Environmental Earth Sciences, v. 66, p. 1667-1681. [Also available at https://doi.org/10.1007/s12665-011-0976-1.]

Li, L., Lan, H., Guo, C., Zhang, Y., Li, Q., and Wu, Y., 2016, A modified frequency ratio method for landslide susceptibility assessment: Landslides, v. 14, no. 2, p. 727-741. [Also available at https://doi.org/10.1007/s10346-016-0771-x.]

Lobeck, A.K., 1922, The physiography of Porto Rico: New York Academy of Sciences, Scientific Survey of Porto Rico and the Virgin Islands, v. 1, no. 4, p. 301-379.

López, A.M., Hughes, K.S., and Vanacore, E., 2020, Puerto Rico's winter 2019-2020 seismic sequence leaves the island on edge: Temblor, January 7, 2020, accessed January 13, 2020, at http://doi.org/10.32858/temblor.064. [Also available at https://temblor.net/earthquake-insights/puerto-ricos-winter-2019-2020-seismic-sequence-leaves-the-island-on-edge-10321/.]

Lugo Bendezú, R., Martinez, G., Ortiz Carrero, P., Torres Angleró, K.H., and Hughes, K.S., 2018, Assessing Puerto Rico's physical topography in relation to rainfall-induced mass wasting sites post Hurricane María, in Geological Society of America Annual Meeting, Indianapolis, Ind., 2018, Abstracts with Programs: Boulder, Colo., Geological Society of America, Paper 171-12, v. 50, no. 6, accessed February 28, 2020, at https://doi.org/10.1130/abs/2018AM-320601.

Lugo-Camacho, J.L., 2008, Soil survey of San Germán area, Puerto Rico: U.S. Department of Agriculture Natural Resources Conservation Service, 964 p. [Also available at https://www.nrcs.usda.gov/Internet/FSE_MANUSCRIPTS/puerto_rico/ PR787/0/SanGerman.pdf.]

Mann, P., Prentice, C.S., Hippolyte, J.C., Grindlay, N.R., Abrams, L.J., and Laó-Dávila, D., 2005, Reconnaissance study of Late Quaternary faulting along Cerro Goden fault zone, western Puerto Rico, in Mann, P., ed., Active tectonics and seismic hazards of Puerto Rico, the Virgin Islands, and offshore areas, Geological Society of America Special Paper 385, p. 115-138. [Also available at https://doi.org/10.1130/0-8137-2385-X.115.]

Mattson, P.H., 1968, Geologic map of the Adjuntas quadrangle, Puerto Rico: U.S. Geological Survey Miscellaneous Geologic Investigations Map IMAP 519, 1 pl., scale 1:20,000. [Also available at https://doi.org/10.3133/i519.]

McIntyre, D.H., Geologic map of the central La Plata quadrangle, Puerto Rico: U.S. Geological Survey Miscellaneous Geologic Investigations Map IMAP 660, 1 pl., scale 1:20,000. [Also available at https://doi.org/10.3133/i660.]

Metro Puerto Rico, 2017, Derrumbe en carretera de Guayanilla hacia Peñuelas: Metro Puerto Rico, December 6, 2017, accessed September 12, 2019, at https://www.metro.pr/pr/noticias/2017/12/06/derrumbe-carretera-guayanilla-hacia-penuelas.html. 
Meyerhoff, H.A., 1927, Tertiary physiographic development of Porto Rico and the Virgin Islands: Geological Society of America Bulletin, v. 38, no. 4, p. 557-576. [Also available at https://doi.org/10.1130/GSAB-38-557.]

Milken Institute School of Public Health, 2018, Ascertainment of the estimated excess mortality from Hurricane María in Puerto Rico: Washington, D.C., George Washington University, 69 p. [Also available at https://www.preventionweb.net/publications/ view/60237.]

Monroe, W.H., 1963, Geology of the Camuy quadrangle, Puerto Rico: U.S. Geological Survey Map GQ-197, 1 pl., scale 1:20,000. [Also available at https://doi.org/10.3133/gq197.]

Monroe, W.H., 1964, Large retrogressive landslides in north-central Puerto Rico, in U.S. Geological Survey, Geological Survey Research 1964 - Chapter B: U.S. Geological Survey Professional Paper 501-B, p. B123-B125. [Also available at https://doi.org/10.3133/pp501B.]

Monroe, W.H., 1967, Geologic map of the Quebradillas quadrangle, Puerto Rico: U.S. Geological Survey Miscellaneous Geologic Investigations Map IMAP 498, 1 pl., scale 1:20,000. [Also available at https://doi.org/10.3133/i498.]

Monroe, W.H., 1969a, Geologic map of the Aguadilla quadrangle, Puerto Rico: U.S. Geological Survey Miscellaneous Geologic Investigations Map IMAP 569, 1 pl., scale 1:20,000. [Also available at https://doi.org/10.3133/i569.]

Monroe, W.H., 1969b, Geologic map of the Moca and Isabela quadrangles, Puerto Rico: U.S. Geological Survey Miscellaneous Geologic Investigations Map IMAP 565, 1 pl., scale 1:20,000. [Also available at https://doi.org/10.3133/i565.]

Monroe, W.H., 1979, Map showing landslides and areas of susceptibility to landsliding in Puerto Rico: U.S. Geological Survey IMAP 1148, 1 pl., scale 1:240,000. [Also available at https://doi.org/10.3133/i1148.]

Monroe, W.H., 1980a, Geology of the middle Tertiary formations of Puerto Rico: U.S. Geological Survey Professional Paper 953, 1 pl., 93 p. [Also available at https://doi.org/10.3133/pp953.]

Monroe, W.H., 1980b, Some tropical landforms of Puerto Rico: U.S. Geological Survey Professional Paper 1159, 1 pl., 39 p. [Also available at https://doi.org/10.3133/pp1159.]

Morales-Vélez, A.C., and Hughes, K.S., 2018, Comprehensive Hurricane María mass wasting inventory and improved frequency ratio landslide hazard mapping - Status update from the University of Puerto Rico at Mayagüez: Dimension, Colegio de Ingenieros y Agrimensores de Puerto Rico, v. 1, p. 23-26. [Also available at https://docs.google.com/a/upr.edu/ viewer? $\mathrm{a}=\mathrm{v} \&$ pid=sites\&srcid=dXByLmVkdXxnZW9sb2d5fGd4OjY5MDk0MWM0OTg0OGRIZDE.]

Moul-Bogunovic, M., 2019, Timing and modern character of the western Puerto Rico fault system using carbonate stratigraphy and fluvial terrace chronology for the Río Culebrinas fault valley: University of Puerto Rico at Mayagüez, M.S. thesis, 105 p. [Also available at https://scholar.uprm.edu/handle/20.500.11801/2442.]

Muñoz, M.A., Lugo, W.I., Santiago, C., Matos, M., Ríos, S., and Lugo, J., 2018, Taxonomic classification of the soils of Puerto Rico, 2017: San Juan, Puerto Rico, University of Puerto Rico, Mayagüez Campus, College of Agricultural Sciences, Agricultural Experiment Station, Bulletin 313, 73 p. [Also available at https://scholar.uprm.edu/handle/20.500.11801/817.]

National Aeronautics and Space Administration [NASA], 2017, SMAP L4 Global 3-hourly 9 km EASE-Grid Surface and Root Zone Soil Moisture Analysis Update, Version 4: National Snow \& Ice Data Center web page, accessed September 12, 2019, at https://nsidc.org/data/SPL4SMAU/versions/4.

National Weather Service, 2017, Update-Impacts of TJUA NEXRAD outage on quantitative precipitation estimates: San Juan, Puerto Rico, National Weather Service Public Information Sheet, October 3, 2017, accessed September 12, 2019, at http://www.weather.gov/media/serfc/PNSQPESJU2.pdf.

NationMaster, 2017, Transport > Road density $>$ Km of road per 100 sq. km of land area-Countries compared: Nation Master website, accessed September 12, 2019, at http://www.nationmaster.com/country-info/stats/Transport/Road-density/ Km-of-road-per-100-sq.-km-of-land-area.

Nelson, A.E., 1967, Geologic map of the Corozal quadrangle, Puerto Rico: U.S. Geological Survey Miscellaneous Geologic Investigations Map IMAP 473, 1 pl., scale 1:20,000. [Also available at https://doi.org/10.3133/i473.]

Nelson, A.E., and Tobisch, O.T., 1968, Geologic map of the Bayaney quadrangle, Puerto Rico: U.S. Geological Survey Miscellaneous Geologic Investigations Map IMAP 525, 1 pl., scale 1:20,000. [Also available at https://doi.org/10.3133/i525.] 
Ortega-Ariza, D., Franseen, E.K., Santos-Mercado, H., Ramírez-Martínez, W.R., and Core-Suárez, E.E., 2015, Strontium isotope stratigraphy for Oligocene-Miocene carbonate systems in Puerto Rico and the Dominican Republic-Implications for Caribbean processes affecting depositional history: The Journal of Geology, v. 123, no. 6, p. 539-560. [Also available at https://www.journals.uchicago.edu/doi/abs/10.1086/683335.]

Pando, M.A., Ruiz, M.E., and Larsen, M.C., 2005, Rainfall-induced landslides in Puerto Rico-An overview in Geo-Frontiers Congress 2005, Austin, Tex., 2005, Abstracts: Reston, Va., American Society of Civil Engineers, p. 2911-2925. [Also available at https://doi.org/10.1061/40787(166)25.]

Pease, M.H., Jr., 1968, Geologic map of the Naranjito quadrangle, Puerto Rico: U.S. Geological Survey Miscellaneous Geologic Investigations Map IMAP 508, 1 pl., scale 1:20,000. [Also available at https://doi.org/10.3133/i508.]

Philpott, S.M., Lin, B.B., Jha, S., and Brines, S.J., 2008, A multi-scale assessment of hurricane impacts on agricultural landscapes based on land use and topographic features: Agriculture, Ecosystems \& Environment, v. 128, no. 1-2, p. 12-20. [Also available at https://doi.org/10.1016/j.agee.2008.04.016.]

Porder, S., Johnson, A.H., Xing, H.X., Brocard, G., Goldsmith, S., and Pett-Ridge, J., 2015, Linking geomorphology, weathering and cation availability in the Luquillo Mountains of Puerto Rico: Geoderma, v. 249-250, p. 100-110. [Also available at https://doi.org/10.1016/j.geoderma.2015.03.002.]

Prentice, C.S., and Mann, P., 2005, Paleoseismic study of the South Lajas fault-First documentation of an onshore Holocene fault in Puerto Rico, in Mann, P., ed., Active tectonics and seismic hazards of Puerto Rico, the Virgin Islands, and offshore areas, Geological Society of America Special Paper 385, p. 215-222. [Also available at https://doi.org/10.1130/0-8137-2385-X.215.]

Puerto Rico Centro de Recaudación de Ingresos Municipales, 1998, Mapa base del CRIM (1996-98), accessed September 12, 2019, at http://gis.otg.pr.gov/downloads/CRIM_Basemap_Project_1996-98/DEM_CRIM.zip.

Puerto Rico Oficina de Gerencia y Presupuesto, 2018, Geología detallada: Government of Puerto Rico, accessed September 12, 2019, at http://gis.otg.pr.gov/downloads/geology/geology20k20181031_gdb.zip.

Ramos-Scharrón, C.E., and Arima, E., 2019, Hurricane María's precipitation signature in Puerto Rico-A conceivable presage of rains to come: Scientific Reports, v. 9, no. 1, article no. 15612, accessed February 28, 2020, at https://doi.org/10.1038/ s41598-019-52198-2.

Ramos-Scharrón, C.E., and LaFevor, M.C., 2016, The role of unpaved roads as active source areas of precipitation excess in small watersheds drained by ephemeral streams in the northeastern Caribbean: Journal of Hydrology, v. 533, p. 168-179. [Also available at https://doi.org/10.1016/j.jhydrol.2015.11.051.]

Regmi, A.D., and Poudel, K., 2016, Assessment of landslide susceptibility using GIS-based evidential belief function in Patu Khola watershed, Dang, Nepal: Environmental Earth Sciences, v. 75, article no. 743, accessed February 28, 2020, at https://doi.org/10.1007/s12665-016-5562-0.

Reid, H.F., and Taber, S., 1919, The Porto Rico earthquake of 1918 with descriptions of earlier earthquakes-Report of the Earthquake Investigation Commission: Washington, D.C., Government Printing Office, 74 p.

Rivera-Santiago, F.O., 2015, High precision GPS monitoring for landslide hazard and land stability evaluation in the Cerca del Cielo urbanization, Ponce, Puerto Rico: University of Puerto Rico at Mayagüez, M.S. thesis, 144 p. [Also available at https://scholar.uprm.edu/handle/20.500.11801/56.]

Roberts, R.C., 1942, Soil survey of Puerto Rico: U.S. Department of Agriculture Bureau of Plant Industry, Series 1936, no. 8, 253 p. [Also available at https://www.nrcs.usda.gov/Internet/FSE_MANUSCRIPTS/puerto_rico/PR1942/puertorico1942a.pdf.]

Rodríguez Feliciano, C.A., Bayouth García, D., and Hughes, K.S., 2019, Volume of slope failures caused by Hurricane María in Puerto Rico using lidar and SfM, in Geological Society of America Annual Meeting, Phoenix, Az., 2019, Abstracts with Programs: Boulder, Colo., Geological Society of America, Paper 42-2, v. 51, no. 5, accessed February 28, 2020, at https://doi.org/10.1130/abs/2019AM-335978.

Rodríguez-Pérez, C., Vázquez Castillo, L., Rodriguez-Molina, C., and Vázquez Castillo, A., 1988, A study of a road landslide in Puerto Rico, in Second International Conference on Case Histories in Geotechnical Engineering, St. Louis, Mo., 1988, Proceedings: St. Louis, Mo., Missouri University of Science and Technology, Paper 2.16, p. 151-157. [Also available at https://scholarsmine.mst.edu/cgi/viewcontent.cgi?article=1440\&context=icchge.] 
Sanger, J.P., Gannett, H., Willcox, W.F., and United States War Department, 1900, Report on the census of Porto Rico, 1899: Washington, D.C., Government Printing Office, 417 p.

Santiago, M., and Larsen, M.C., 2001, Map showing susceptibility to earthquake-induced landsliding, San Juan metropolitan area, Puerto Rico: U.S. Geological Survey Open-File Report 2001-39, 2 pls., scale 1:20,000, accessed February 28, 2020, at https://doi.org/10.3133/ofr200139.

Santiago-Pérez, Y., Odom, W.E., III, and Hughes, K.S., 2019, Relict Caribbean topography and tectonically triggered erosion rates in the Cordillera Central of Puerto Rico in Geological Society of America Annual Meeting, Phoenix, Az., 2019 Abstracts with Programs: Boulder, Colo., Geological Society of America, Paper 263-7, v. 51, no. 5, accessed February 28, 2020, at https://doi.org/10.1130/abs/2019AM-338288.

Schulz, W.H., 2007, Landslide susceptibility revealed by lidar imagery and historical records, Seattle, Washington: Engineering Geology, v. 89, no. 1-2, p. 67-87. [Also available at https://doi.org/10.1016/j.enggeo.2006.09.019.]

Schwartz, S.B., 1992, The Hurricane of San Ciriaco-Disaster, politics, and society in Puerto Rico, 1899-1901: Hispanic American Historical Review, v. 72, no. 3, p. 303-334. [Also available at http://doi.org/10.2307/2515987.]

Sidle, R.C., and Ochiai, H., 2006, Landslides_-Processes, prediction, and land use: Washington, D.C., American Geophysical Union, Water Resources Monograph 18, 312 p. [Also available at http://doi.org/10.1029/WM018.]

Silva-Tulla, F., 1986, The October 1985 landslide at Barrio Mameyes, Ponce, Puerto Rico: Washington, D.C., National Academies Press, $14 \mathrm{p}$.

Silva-Tulla, F., Pando, M.A., Soto, A.E., Morales, A., Pradel, D., Inci, G., Sasanakul, I., Bernal, J.R., Kayen, R., Hughes, S., Adams, T., and Park, Y., 2018, Geotechnical impacts of Hurricane María in Puerto Rico: Geotechnical Extreme Events Reconnaissance, Association Report No. GEER-057, 120 p. [Also available at http://www.geerassociation.org/administrator/components/ com_geer_reports/geerfiles/180629_GEER_PR_Report_No_GEER-057.pdf.]

Simon, A., Larsen, M.C., and Hupp, C.R., 1990, The role of soil processes in determining mechanisms of slope failure and hillslope development in a humid-tropical forest, eastern Puerto Rico: Geomorphology, v. 3, no. 3-4, p. 263-286. [Also available at https://doi.org/10.1016/0169-555X(90)90007-D.]

Soler-López, L.R., 2000, Sedimentation survey of Lago Dos Bocas, Puerto Rico, October 1999: U.S. Geological Survey Water Resources Investigations Report 00-4234, 19 p. [Also available at https://pubs.usgs.gov/wri/2000/4234/report.pdf.]

Taggart, B.E., and Joyce, J., 1990, Radiometrically dated marine terraces on northwestern Puerto Rico, in Larue, D.K., and Draper, G., eds., Transactions of the 12th Caribbean Conference, August 7-11, 1989, St. Croix, V.I.: Miami Geological Society, p. 248-258.

Terzaghi, K., 1950, Mechanism of landslides, in Paige, S., ed., Application of geology to engineering practice - Berkey volume: New York, Geological Society of America, p. 83-124. [Also available at https://doi.org/10.1130/Berkey.1950.]

Tobisch, O.T., and Turner, M.D., 1971, Geologic map of the San Sebastián quadrangle, Puerto Rico: U.S. Geological Survey Miscellaneous Geologic Investigations Map IMAP 661, 1 pl., scale 1:20,000. [Also available at https://doi.org/10.3133/i661.]

U.S. Census Bureau, 2010, 2010 Census-Population density data (text version): United States Census Bureau web page, accessed January 13, 2020, at https://www.census.gov/data/tables/2010/dec/density-data-text.html.

U.S. Census Bureau, 2015, 2015 TIGER/Line Shapefiles, State, Puerto Rico, primary and secondary roads State-based Shapefile: United States Census Bureau, accessed September 12, 2019, at http:/www2.census.gov/geo/tiger/TIGER2015/ PRISECROADS/tl_2015_72_prisecroads.zip.

U.S. Department of Agriculture [USDA], 2018, Web soil survey: U.S. Department of Agriculture Natural Resources Conservation Service web page, accessed September 12, 2019, at https://websoilsurvey.sc.egov.usda.gov/App/WebSoilSurvey.aspx.

U.S. Geological Survey [USGS], 2017, 2015-2016 USGS Puerto Rico lidar: U.S. Geological Survey, accessed September 12, 2019, at ftp://rockyftp.cr.usgs.gov/vdelivery/Datasets/Staged/Elevation/OPR/PR_PuertoRico_2015/.

U.S. Geological Survey [USGS], 2019, NHD 20190815 for Puerto Rico State or territory Shapefile model version 2.2.1: U.S. Geological Survey web page, accessed September 12, 2019, at https://www.sciencebase.gov/catalog/item/5a96cdc6e4b06990606c4d7c. 


\section{Map Depicting Susceptibility to Landslides Triggered by Intense Rainfall, Puerto Rico}

Varnes, D.J., 1984, Landslide hazard zonation-A review of principles and practice: Paris, United Nations, Natural Hazards, no. $3,63 \mathrm{p}$.

Vazquez Torres, J., 2013, Tremenda desgracia en Bayamón—Fotos y videos: Primera Hora, August 21, 2013, accessed September 12, 2019, at https://www.primerahora.com/noticias/policia-tribunales/nota/tremendadesgraciaenbayamon-fotosyvideos-947498/.

Wang, G., 2012, Kinematics of the Cerca del Cielo, Puerto Rico landslide derived from GPS observations: Landslides, v. 9 , no. 1, p. 117-130. [Also available at https://doi.org/10.1007/s10346-011-0277-5.]

Wang, G., 2013, Millimeter-accuracy GPS landslide monitoring using Precise Point Positioning with Single Receiver Phase Ambiguity (PPP-SRPA) resolution-A case study in Puerto Rico: Journal of Geodetic Science, v. 3, no. 1, p. 22-31. [Also available at https://doi.org/10.2478/jogs-2013-0001.]

Wang, G., Joyce, J., Phillips, D., Shrestha, R., and Carter, W., 2013, Delineating and defining the boundaries of an active landslide in the rainforest of Puerto Rico using a combination of airborne and terrestrial lidar data: Landslides, v. 10, no. 4, p. 503-513. [Also available at https://doi.org/10.1007/s10346-013-0400-x.]

White, A.F., and Blum, A.E., 1995, Effects of climate on chemical weathering in watersheds: Geochimica et Cosmochimica Acta, v. 59, no. 9, p. 1729-1747. [Also available at https://doi.org/10.1016/0016-7037(95)00078-E.]

White, A.F., Blum, A.E., Schulz, M.S., Vivit, D.V., Stonestrom, D.A., Larsen, M., Murphy, S.F., and Eberl, D., 1998, Chemical weathering in a tropical watershed, Luquillo Mountains, Puerto Rico-I. Long-term versus short-term weathering fluxes: Geochimica et Cosmochimica Acta, v. 62, no. 2, p. 209-226. [Also available at https://doi.org/10.1016/S0016-7037(97)00335-9.]

Xu, C., Xu, X., Dai, F., and Saraf, A.K., 2012, Comparison of different models for susceptibility mapping of earthquake triggered landslides related with the 2008 Wenchuan earthquake in China: Computers \& Geosciences, v. 46, p. 317-329. [Also available at https://doi.org/10.1016/j.cageo.2012.01.002.]

Zachariasen, J., and von Hillebrandt-Andrade, C.G., 2005, Holocene faulting of the Cero Goden fault, western Puerto Rico: National Earthquake Hazards Reduction Program, Final Technical Report, Grant Award Number 05HQGR0082, 27 p., accessed February 5, 2020, at https://earthquake.usgs.gov/cfusion/external_grants/reports/05HQGR0082.pdf.

Publishing support provided by the Science Publishing Network,

Denver Publishing Service Center

For more information concerning the research in this report, contact the

Center Director, USGS Geologic Hazards Science Center

Box 25046, Mail Stop 966

Denver, CO 80225

(303) 273-8579

Or visit Geologic Hazards Science Center website at

https://www.usgs.gov/centers/geohazards 


\section{Appendix 1. Key for Municipality Abbreviations}

\begin{tabular}{llllll}
\hline \multicolumn{1}{c}{ Abbreviation } & \multicolumn{1}{c}{ Name } & \multicolumn{1}{c}{ Abbreviation } & \multicolumn{1}{c}{ Name } & \multicolumn{1}{c}{ Abbreviation } & \multicolumn{1}{c}{ Name } \\
\hline ADJ & Adjuntas & FLO & Florida & NAR & Naranjito \\
AGA & Aguada & GUA & Guánica & ORO & Orocovis \\
AGL & Aguadilla & GMA & Guayama & PAT & Patillas \\
AGB & Aguas Buenas & GNA & Guayanilla & PEN & Peñuelas \\
AIB & Aibonito & GYB & Guaynabo & PON & Ponce \\
ARE & Arecibo & GUR & Gurabo & QUE & Quebradillas \\
ARY & Arroyo & HAT & Hatillo & RIN & Rincón \\
ANA & Añasco & HOR & Hormigueros & RIO & Rio Grande \\
BAR & Barceloneta & HUM & Humacao & SAL & Salinas \\
BAQ & Barranquitas & ISA & Isabela & SAB & Sabana Grande \\
BAY & Bayamón & JAY & Jayuya & SGM & San Germán \\
CAG & Caguas & JDZ & Juana Díaz & SJU & San Juan \\
CBR & Cabo Rojo & JUN & Juncos & SLO & San Lorenzo \\
CAM & Camuy & LAJ & Lajas & SSB & San Sebastián \\
CAN & Canóvanas & LAR & Lares & SIB & Santa Isabel \\
CAR & Carolina & LMA & Las Marías & TAL & Toa Alta \\
CAT & Cataño & LPI & Las Piedras & TBA & Toa Baja \\
CAY & Cayey & LOI & Loíza & TRU & Trujillo Alto \\
CEI & Ceiba & LUQ & Luquillo & UTU & Utuado \\
CIA & Ciales & MAN & Manatí & VAL & Vega Alta \\
CID & Cidra & MAR & Maricao & VBA & Vega Baja \\
COA & Coamo & MAU & Maunabo & VIL & Villalba \\
COM & Comerío & MAY & Mayagüez & YAB & Yabucoa \\
COR & Corozal & MOC & Moca & YAU & Yauco \\
DOR & Dorado & MOR & Morovis & & \\
FAJ & Fajardo & NAG & Naguabo & & \\
\hline
\end{tabular}




\section{Appendix 2. Results from Analyses of Land Cover}

$\left[\mathrm{km}^{2}\right.$, square kilometer; \%, percent; \#, number; FR, frequency ratio; SI, Susceptibility Index $]$

\begin{tabular}{|c|c|c|c|c|c|c|c|}
\hline VALUE & CLASS_NAME & $\begin{array}{l}\text { Area } \\
\left(\mathrm{km}^{2}\right)\end{array}$ & $\begin{array}{l}\text { Area } \\
(\%)\end{array}$ & $\begin{array}{l}\text { Landslides } \\
\qquad(\#)\end{array}$ & $\begin{array}{l}\text { Landslides } \\
\quad(\%)\end{array}$ & FR & SI \\
\hline 43 & Montane wet evergreen abandoned and active coffee plantation & 548.9 & 0.063 & 13920 & 0.2598 & 4.12 & 1.42 \\
\hline 38 & Young secondary montane wet noncalcareous evergreen forest & 216.7 & 0.0249 & 4018 & 0.075 & 3.02 & 1.1 \\
\hline 32 & Montane wet alluvial shrubland and woodland & 9 & 0.001 & 120 & 0.0022 & 2.17 & 0.77 \\
\hline 29 & Lowland moist abandoned and active coffee plantations & 110.8 & 0.0127 & 1269 & 0.0237 & 1.86 & 0.62 \\
\hline 33 & Mature secondary montane wet noncalcareous evergreen forest & 252.3 & 0.029 & 2672 & 0.0499 & 1.72 & 0.54 \\
\hline 31 & Young secondary montane wet alluvial evergreen forest & 9.9 & 0.0011 & 92 & 0.0017 & 1.51 & 0.41 \\
\hline 36 & $\begin{array}{l}\text { Mature primary Sierra Palm and secondary montane wet noncalcareous } \\
\text { evergreen forest }\end{array}$ & 119.7 & 0.0137 & 869 & 0.0162 & 1.18 & 0.17 \\
\hline 27 & Young secondary lowland moist noncalcareous evergreen forest & 530.5 & 0.0609 & 3077 & 0.0574 & 0.94 & -0.06 \\
\hline 40 & Mature secondary montane wet serpentine evergreen forest & 33.8 & 0.0039 & 198 & 0.0037 & 0.95 & -0.05 \\
\hline 26 & Mature secondary lowland moist noncalcareous evergreen forest & 378.5 & 0.0434 & 1671 & 0.0312 & 0.72 & -0.33 \\
\hline 41 & Young secondary montane wet serpentine evergreen forest & 6.5 & 0.0007 & 25 & 0.0005 & 0.62 & -0.47 \\
\hline 64 & Low-density urban development & 369.3 & 0.0424 & 990 & 0.0185 & 0.44 & -0.83 \\
\hline 22 & Lowland moist alluvial shrubland and woodland & 51.2 & 0.0059 & 123 & 0.0023 & 0.39 & -0.94 \\
\hline 65 & Artificial barrens & 85.8 & 0.0098 & 198 & 0.0037 & 0.38 & -0.98 \\
\hline 20 & Mature secondary lowland moist alluvial evergreen forest & 21.3 & 0.0024 & 49 & 0.0009 & 0.37 & -0.98 \\
\hline 37 & $\begin{array}{l}\text { Mature primary elfin woodland and secondary montane wet } \\
\text { noncalcareous evergreen cloud forest }\end{array}$ & 15.4 & 0.0018 & 34 & 0.0006 & 0.36 & -1.02 \\
\hline 21 & Young secondary lowland moist alluvial evergreen forest & 66.7 & 0.0077 & 137 & 0.0026 & 0.33 & -1.1 \\
\hline 34 & $\begin{array}{l}\text { Mature primary Tabonuco and secondary montane wet noncalcareous } \\
\text { evergreen forest }\end{array}$ & 87.3 & 0.01 & 177 & 0.0033 & 0.33 & -1.11 \\
\hline 35 & $\begin{array}{l}\text { Mature primary Palo Colorado and secondary montane wet } \\
\text { noncalcareous evergreen forest }\end{array}$ & 37.2 & 0.0043 & 49 & 0.0009 & 0.21 & -1.54 \\
\hline 16 & Mature secondary dry and moist serpentine semideciduous forest & 18.4 & 0.0021 & 22 & 0.0004 & 0.19 & -1.64 \\
\hline 24 & Young secondary moist limestone evergreen and semideciduous forest & 155 & 0.0178 & 136 & 0.0025 & 0.14 & -1.95 \\
\hline 17 & Young secondary dry and moist serpentine semideciduous forest & 19.6 & 0.0023 & 10 & 0.0002 & 0.08 & -2.49 \\
\hline 18 & Dry and moist serpentine woodland and shrubland & 8.4 & 0.001 & 4 & 0.0001 & 0.08 & -2.56 \\
\hline 25 & Moist limestone shrubland and woodland & 103.4 & 0.0119 & 58 & 0.0011 & 0.09 & -2.39 \\
\hline 7 & Lowland dry limestone woodland and shrubland & 50 & 0.0057 & 18 & 0.0003 & 0.06 & -2.84 \\
\hline 23 & Mature secondary moist limestone evergreen and semideciduous forest & 464.6 & 0.0533 & 130 & 0.0024 & 0.05 & -3.09 \\
\hline 6 & Young secondary lowland dry limestone semideciduous forest & 39.1 & 0.0045 & 8 & 0.0001 & 0.03 & -3.4 \\
\hline
\end{tabular}




\begin{tabular}{|c|c|c|c|c|c|c|c|}
\hline VALUE & CLASS_NAME & $\begin{array}{l}\text { Area } \\
\left(\mathbf{k m}^{2}\right)\end{array}$ & $\begin{array}{c}\text { Area } \\
(\%)\end{array}$ & $\begin{array}{l}\text { Landslides } \\
\text { (\#) }\end{array}$ & $\begin{array}{c}\text { Landslides } \\
(\%)\end{array}$ & $\mathbf{F R}$ & SI \\
\hline 15 & Lowland dry noncalcareous shrubland and woodland & 104.7 & 0.012 & 21 & 0.0004 & 0.03 & -3.42 \\
\hline 13 & Mature secondary lowland dry noncalcareous semideciduous forest & 21.6 & 0.0025 & 3 & 0.0001 & 0.02 & -3.79 \\
\hline 14 & Young secondary lowland dry noncalcareous semideciduous forest & 36.1 & 0.0041 & 3 & 0.0001 & 0.01 & -4.3 \\
\hline 59 & Fine to coarse sandy beaches, mixed sand and gravel beaches & 6.7 & 0.0008 & 1 & 0 & 0.02 & -3.71 \\
\hline 48 & Dry grasslands and pastures & 406.9 & 0.0467 & 36 & 0.0007 & 0.01 & -4.24 \\
\hline 3 & Lowland dry alluvial shrubland and woodland & 42.4 & 0.0049 & 5 & 0.0001 & 0.02 & -3.95 \\
\hline 66 & Freshwater & 44.2 & 0.0051 & 5 & 0.0001 & 0.02 & -4 \\
\hline 63 & High-density urban development & 522.8 & 0.06 & 38 & 0.0007 & 0.01 & -4.44 \\
\hline 53 & Seasonally flooded herbaceous nonsaline wetlands & 182.4 & 0.0209 & 15 & 0.0003 & 0.01 & -4.31 \\
\hline 55 & Hay and row crops & 257.9 & 0.0296 & 16 & 0.0003 & 0.01 & -4.6 \\
\hline 5 & Mature secondary lowland dry limestone semideciduous forest & 93.4 & 0.0107 & 6 & 0.0001 & 0.01 & -4.56 \\
\hline 1 & Mature secondary lowland dry alluvial semideciduous forest & 5.1 & 0.0006 & 0 & 0 & 0 & -5 \\
\hline 2 & Young secondary lowland dry alluvial semideciduous forest & 28.8 & 0.0033 & 0 & 0 & 0 & -5 \\
\hline 4 & Mature secondary lowland dry limestone evergreen forest & 8.8 & 0.001 & 0 & 0 & 0 & -5 \\
\hline 8 & Lowland dry limestone shrubland & 36.8 & 0.0042 & 0 & 0 & 0 & -5 \\
\hline 10 & Coastal dwarf woodland and shrubland & 0.1 & 0 & 0 & 0 & 0 & -5 \\
\hline 44 & Mangrove forest and shrubland & 76 & 0.0087 & 0 & 0 & 0 & -5 \\
\hline 45 & Freshwater Pterocarpus swamp & 2.6 & 0.0003 & 0 & 0 & 0 & -5 \\
\hline 46 & Lowland dry riparian forest & 6.9 & 0.0008 & 0 & 0 & 0 & -5 \\
\hline 47 & Lowland dry riparian shrubland and woodland & 4.2 & 0.0005 & 0 & 0 & 0 & -5 \\
\hline 49 & Dry cactus grassland and shrubland & 2.1 & 0.0002 & 0 & 0 & 0 & -5 \\
\hline 51 & Emergent herbaceous nonsaline wetlands & 11 & 0.0013 & 0 & 0 & 0 & -5 \\
\hline 52 & Emergent herbaceous saline wetlands & 8.8 & 0.001 & 0 & 0 & 0 & -5 \\
\hline 54 & Seasonally flooded herbaceous saline wetlands & 48.5 & 0.0056 & 0 & 0 & 0 & -5 \\
\hline 56 & Woody agriculture and plantations: Palm plantations & 4.9 & 0.0006 & 0 & 0 & 0 & -5 \\
\hline 57 & Rocky cliffs and shelves & 1.4 & 0.0002 & 0 & 0 & 0 & -5 \\
\hline 58 & Gravel beaches and stony shoreline & 0.3 & 0 & 0 & 0 & 0 & -5 \\
\hline 60 & Riparian and other natural barrens & 4.5 & 0.0005 & 0 & 0 & 0 & -5 \\
\hline 61 & Salt and mudflats & 12.4 & 0.0014 & 0 & 0 & 0 & -5 \\
\hline 62 & Salt production & 0.2 & 0 & 0 & 0 & 0 & -5 \\
\hline 67 & Salt water & 32.6 & 0.0037 & 0 & 0 & 0 & -5 \\
\hline 68 & Lowland moist riparian forest & 9.1 & 0.001 & 0 & 0 & 0 & -5 \\
\hline 69 & Lowland moist riparian shrubland and woodland & 5.1 & 0.0006 & 0 & 0 & 0 & -5 \\
\hline 70 & Aquiculture & 1 & 0.0001 & 0 & 0 & 0 & -5 \\
\hline
\end{tabular}




\section{Appendix 3. Results from Analyses of Soil Class}

[MUKEY, mapunit key; MUSYM, mapunit symbol; MUNAME, mapunit name; km², square kilometer; \%, percent; \#, number; FR, frequency ratio; SI, Susceptibility Index; >, greater than]

\begin{tabular}{|c|c|c|c|c|c|c|c|c|}
\hline MUKEY & MUSYM & MUNAME & $\begin{array}{l}\text { Area } \\
\left(\mathrm{km}^{2}\right)\end{array}$ & $\begin{array}{c}\text { Area } \\
(\%)\end{array}$ & $\begin{array}{c}\text { Landslides } \\
\text { (\#) }\end{array}$ & $\begin{array}{c}\text { Landslides } \\
(\%)\end{array}$ & FR & SI \\
\hline 326463 & $\mathrm{PeF}$ & Pellejas clay loam, 40 to 60 percent slopes & 98.9 & 0.0114 & 8524 & 0.1591 & 14.01 & 2.64 \\
\hline 326577 & $\mathrm{MrF} 2$ & Maricao clay, 20 to 60 percent slopes & 3.8 & 0.0004 & 295 & 0.0055 & 12.65 & 2.54 \\
\hline 326445 & LcF2 & Lirios clay loam, 40 to 60 percent slopes, eroded & 59.1 & 0.0068 & 3802 & 0.071 & 10.47 & 2.35 \\
\hline 326566 & LuF2 & Los Guineos clay, 20 to 60 percent slopes, eroded & 6.9 & 0.0008 & 374 & 0.007 & 8.78 & 2.17 \\
\hline 1386404 & $\mathrm{MkF}$ & Maricao clay, 20 to 60 percent slopes & 11.1 & 0.0013 & 452 & 0.0084 & 6.63 & 1.89 \\
\hline 326414 & $\mathrm{CoF}$ & Consejo clay, 40 to 60 percent slopes & 9.1 & 0.001 & 361 & 0.0067 & 6.42 & 1.86 \\
\hline 326702 & $\mathrm{PeF}$ & Pellejas clay loam, 40 to 60 percent slopes & 2.7 & 0.0003 & 105 & 0.002 & 6.3 & 1.84 \\
\hline 326437 & InE & Ingenio clay loam, 20 to 40 percent slopes & 1.7 & 0.0002 & 66 & 0.0012 & 6.22 & 1.83 \\
\hline 326530 & $\mathrm{CoF} 2$ & Consumo clay, 40 to 60 percent slopes & 157.6 & 0.0181 & 4863 & 0.0908 & 5.02 & 1.61 \\
\hline 326550 & $\mathrm{HmF} 2$ & Humatas clay, 40 to 60 percent slopes & 120 & 0.0138 & 3594 & 0.0671 & 4.87 & 1.58 \\
\hline 1385065 & $\mathrm{HmF}$ & Humatas clay, 40 to 60 percent slopes & 6.4 & 0.0007 & 191 & 0.0036 & 4.84 & 1.58 \\
\hline 326435 & $\mathrm{HmF}$ & Humatas clay, 40 to 60 percent slopes & 82.9 & 0.0095 & 2468 & 0.0461 & 4.84 & 1.58 \\
\hline 326608 & RsF2 & Rosario clay, 40 to 60 percent slopes, eroded & 0.1 & 0 & 3 & 0.0001 & 4.77 & 1.56 \\
\hline 1379812 & $\mathrm{CsF}$ & Consumo clay, 40 to 60 percent slopes & 5.6 & 0.0006 & 161 & 0.003 & 4.64 & 1.54 \\
\hline 326656 & $\mathrm{CuF}$ & Consumo clay, 40 to 60 percent slopes & 68.6 & 0.0079 & 1946 & 0.0363 & 4.61 & 1.53 \\
\hline 1385087 & $\mathrm{AbF}$ & Agueybana clay, 12 to 60 percent slopes & 13.1 & 0.0015 & 351 & 0.0066 & 4.35 & 1.47 \\
\hline 326591 & $\mathrm{MxF}$ & Mucara clay, 40 to 60 percent slopes & 20 & 0.0023 & 475 & 0.0089 & 3.87 & 1.35 \\
\hline 326830 & $\mathrm{MkF} 2$ & Maricao clay, 20 to 60 percent slopes & 34 & 0.0039 & 615 & 0.0115 & 2.94 & 1.08 \\
\hline 326587 & MwF2 & Morado clay loam, 40 to 60 percent slopes & 26.7 & 0.0031 & 466 & 0.0087 & 2.84 & 1.04 \\
\hline 326447 & $\operatorname{LgE}$ & Los Guineos clay, 20 to 40 percent slopes & 9.4 & 0.0011 & 156 & 0.0029 & 2.71 & 1 \\
\hline 326449 & $\mathrm{MaF} 2$ & Maraguez silty clay loam, 40 to 60 percent slopes, eroded & 24.5 & 0.0028 & 393 & 0.0073 & 2.61 & 0.96 \\
\hline 326511 & AoF2 & Anones clay loam, 40 to 60 percent slopes, eroded & 10.5 & 0.0012 & 166 & 0.0031 & 2.56 & 0.94 \\
\hline 326812 & $\mathrm{HmF} 2$ & Humatas clay, 40 to 60 percent slopes & 66.6 & 0.0076 & 1047 & 0.0195 & 2.56 & 0.94 \\
\hline 326458 & $\mathrm{MuF}$ & Mucara clay, 40 to 60 percent slopes & 54.3 & 0.0062 & 816 & 0.0152 & 2.45 & 0.89 \\
\hline 326415 & $\mathrm{CpE}$ & Consumo clay, 20 to 40 percent slopes & 0.6 & 0.0001 & 9 & 0.0002 & 2.42 & 0.88 \\
\hline 326517 & $\mathrm{CbF}$ & Caguabo clay loam, 20 to 60 percent slopes & 51.1 & 0.0059 & 753 & 0.0141 & 2.4 & 0.87 \\
\hline 326507 & AdE2 & Aibonito clay, 20 to 40 percent slopes, eroded & 0.5 & 0.0001 & 7 & 0.0001 & 2.39 & 0.87 \\
\hline 326701 & $\mathrm{PaF}$ & Pandura sandy loam, 40 to 60 percent slopes & 52.6 & 0.006 & 697 & 0.013 & 2.16 & 0.77 \\
\hline 326413 & $\mathrm{CoE}$ & Consejo clay, 20 to 40 percent slopes & 0.7 & 0.0001 & 9 & 0.0002 & 2.08 & 0.73 \\
\hline 328582 & NOTCOM & No Digital Data Available & 1.6 & 0.0002 & 20 & 0.0004 & 2.02 & 0.7 \\
\hline
\end{tabular}




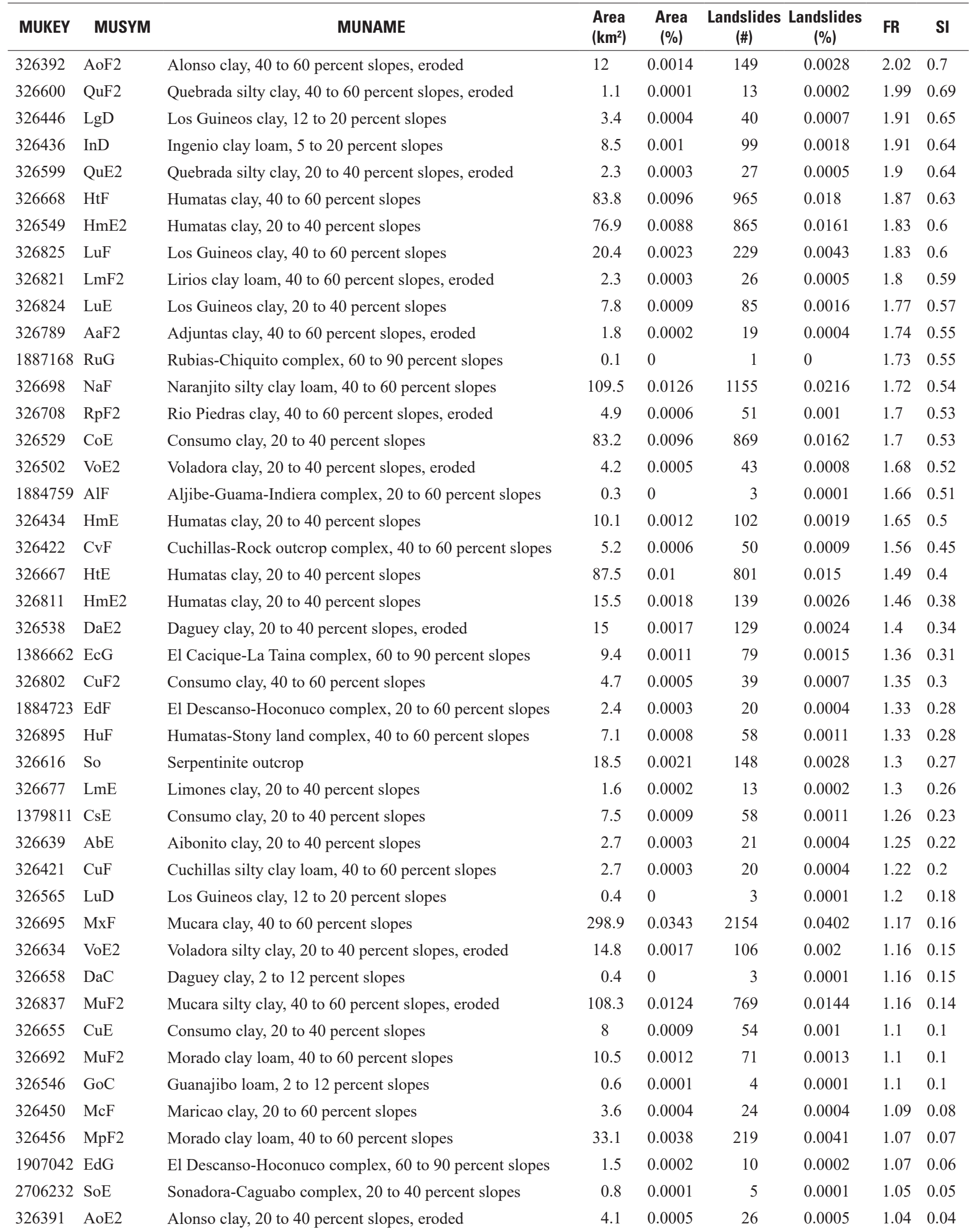




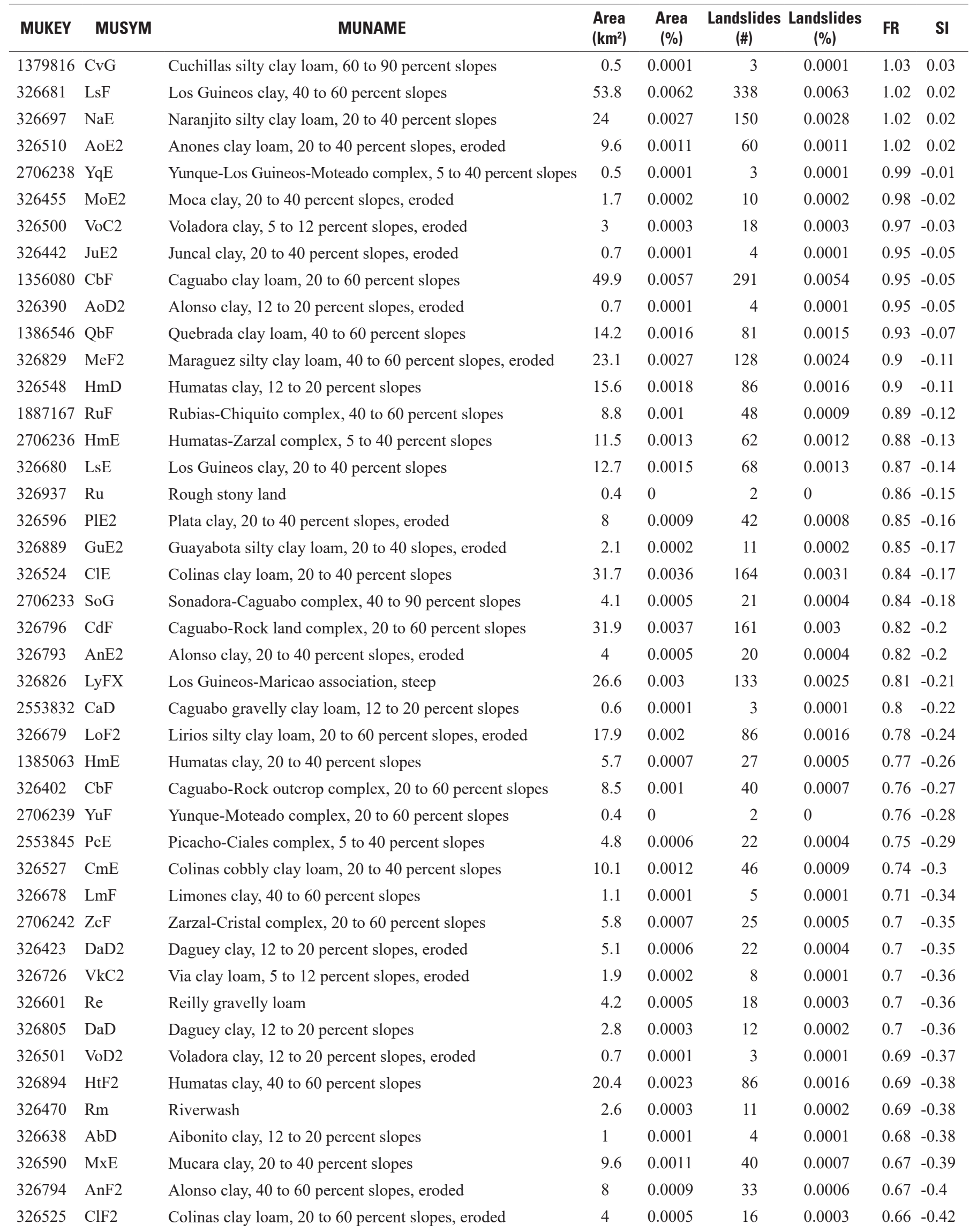




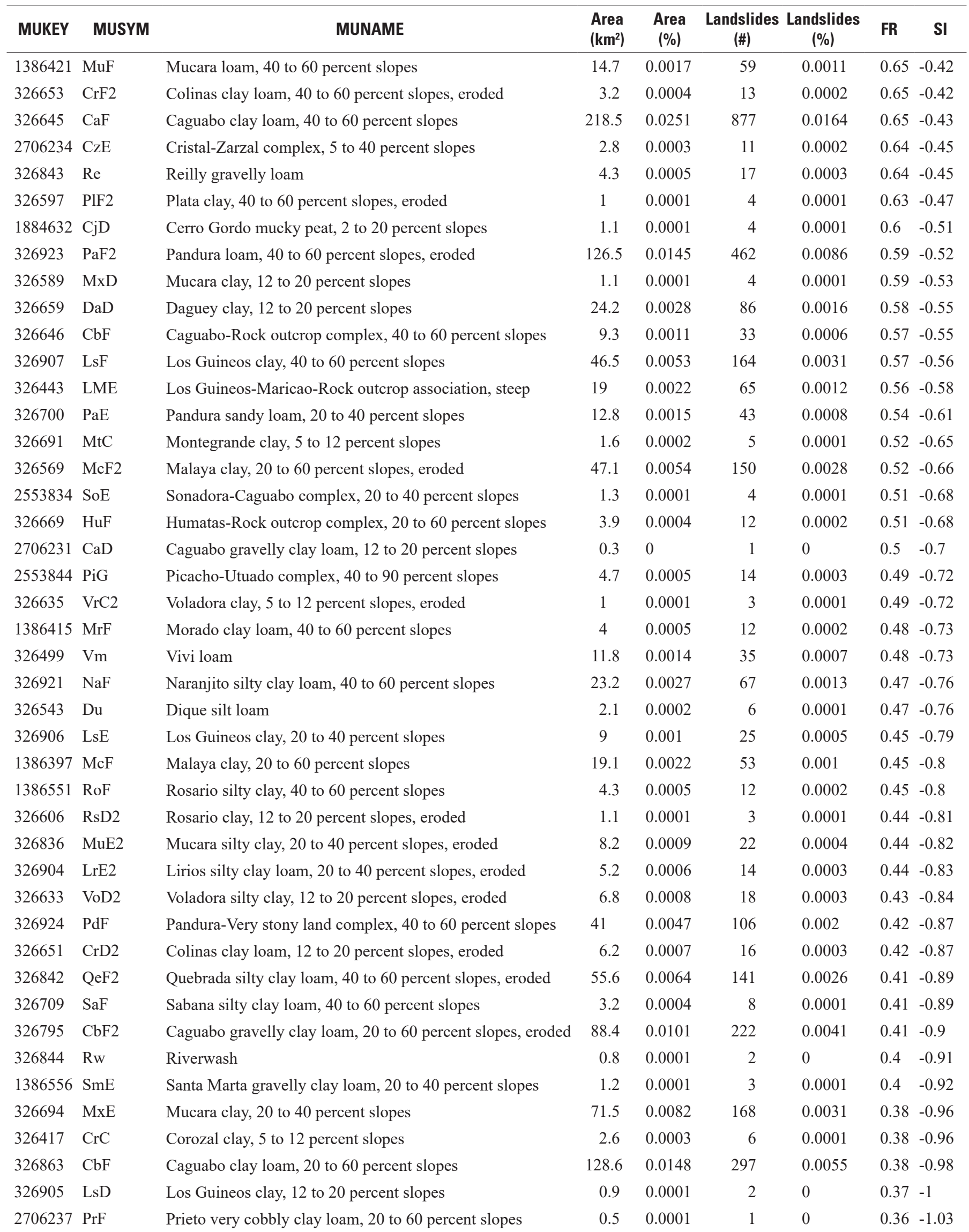









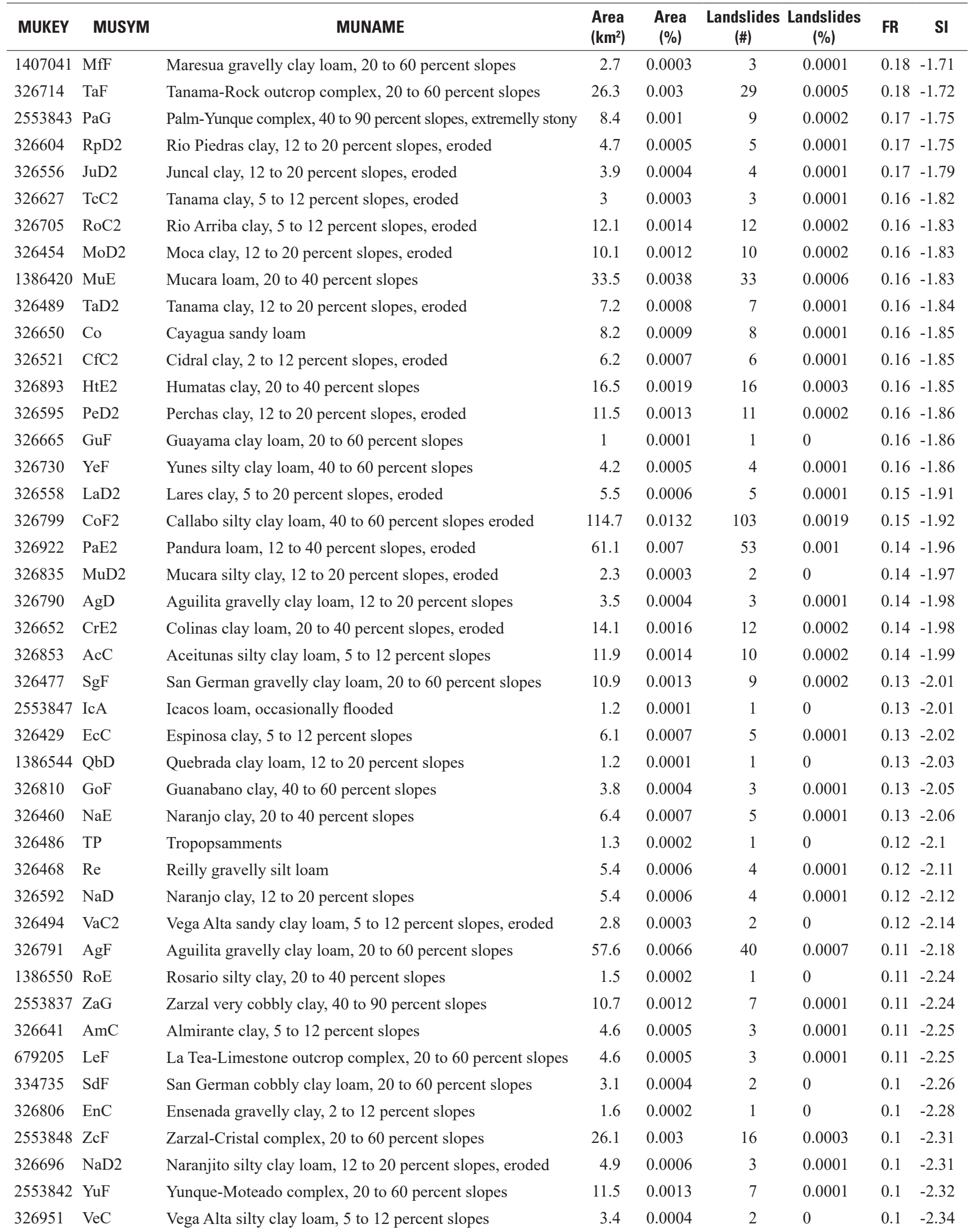




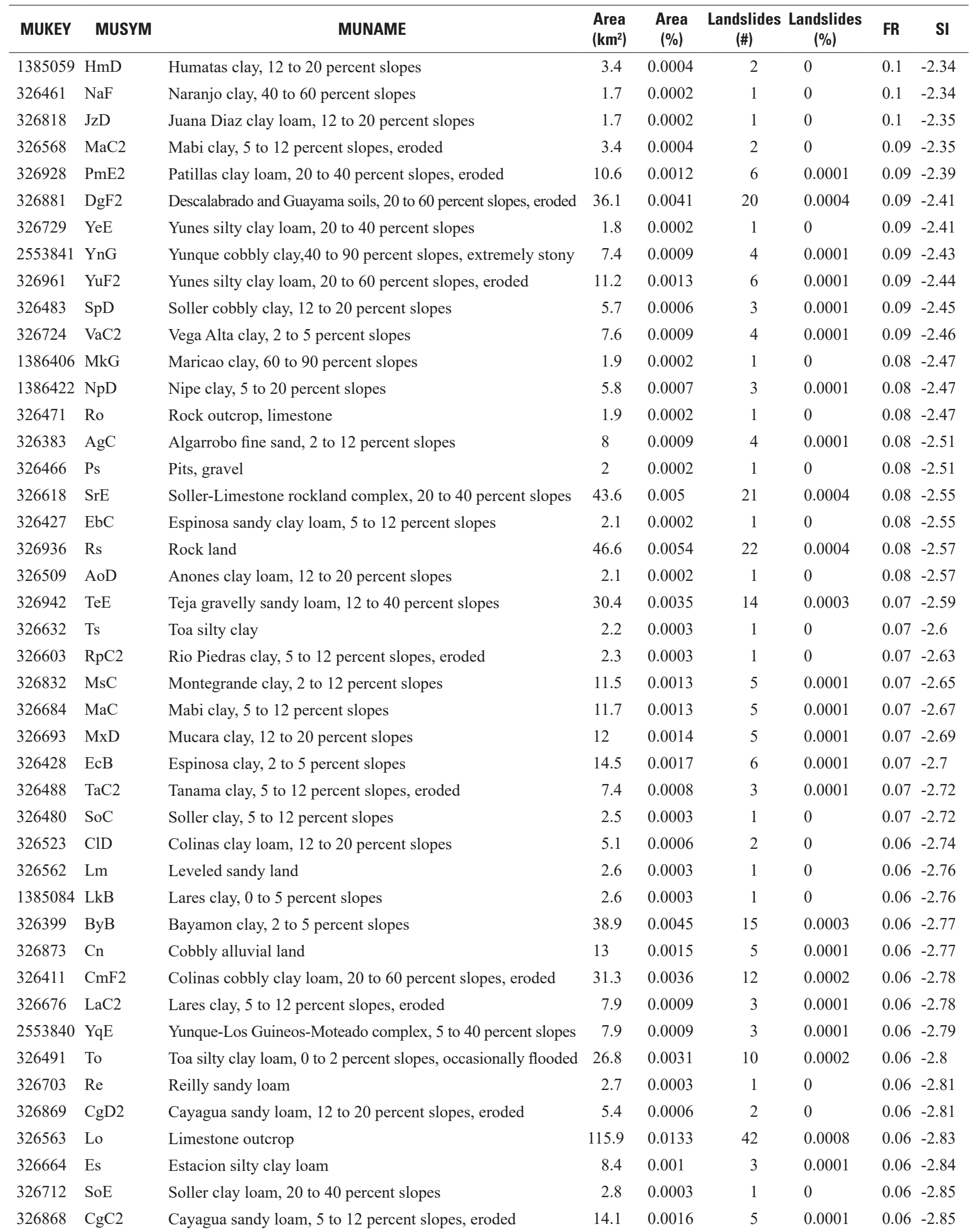




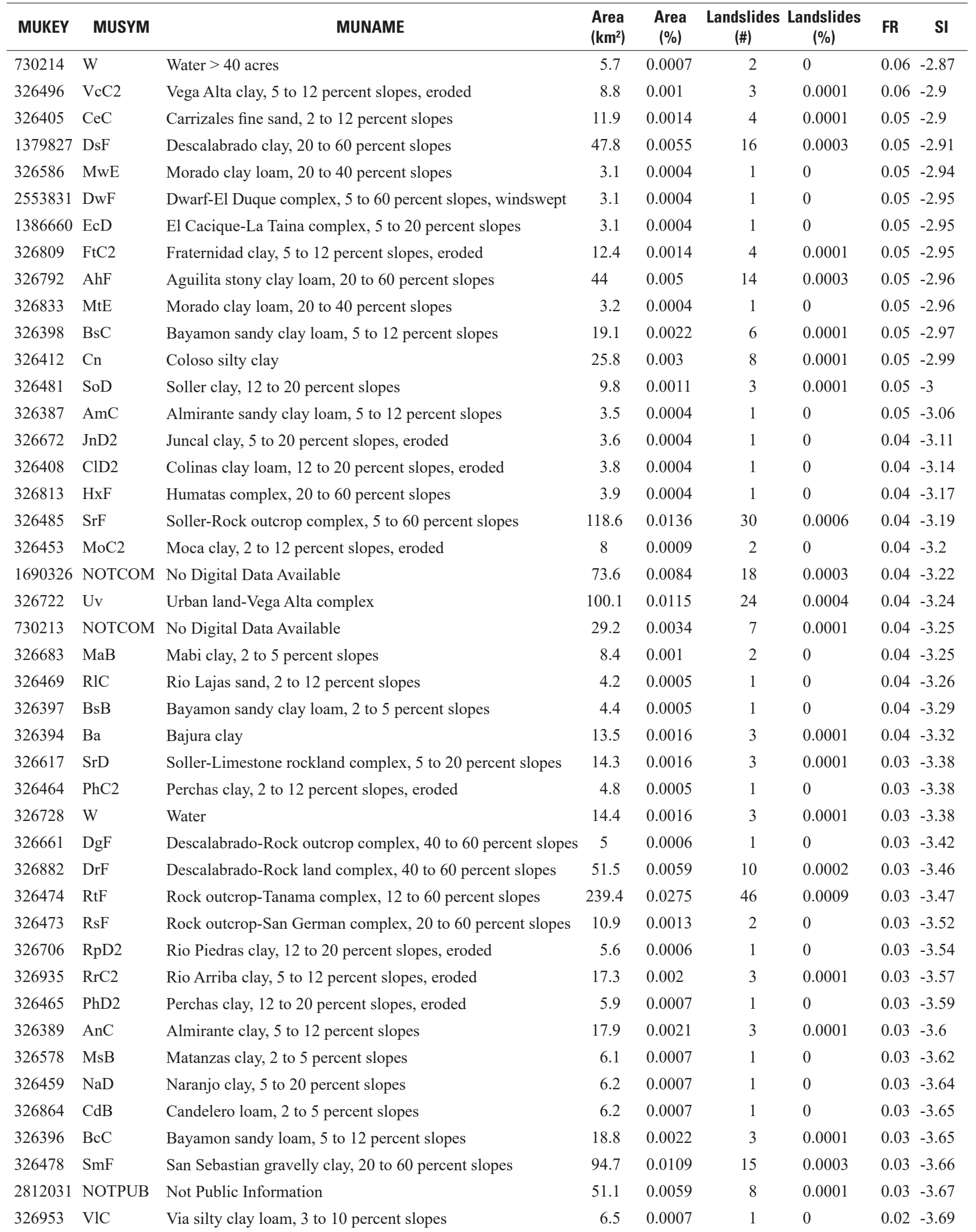




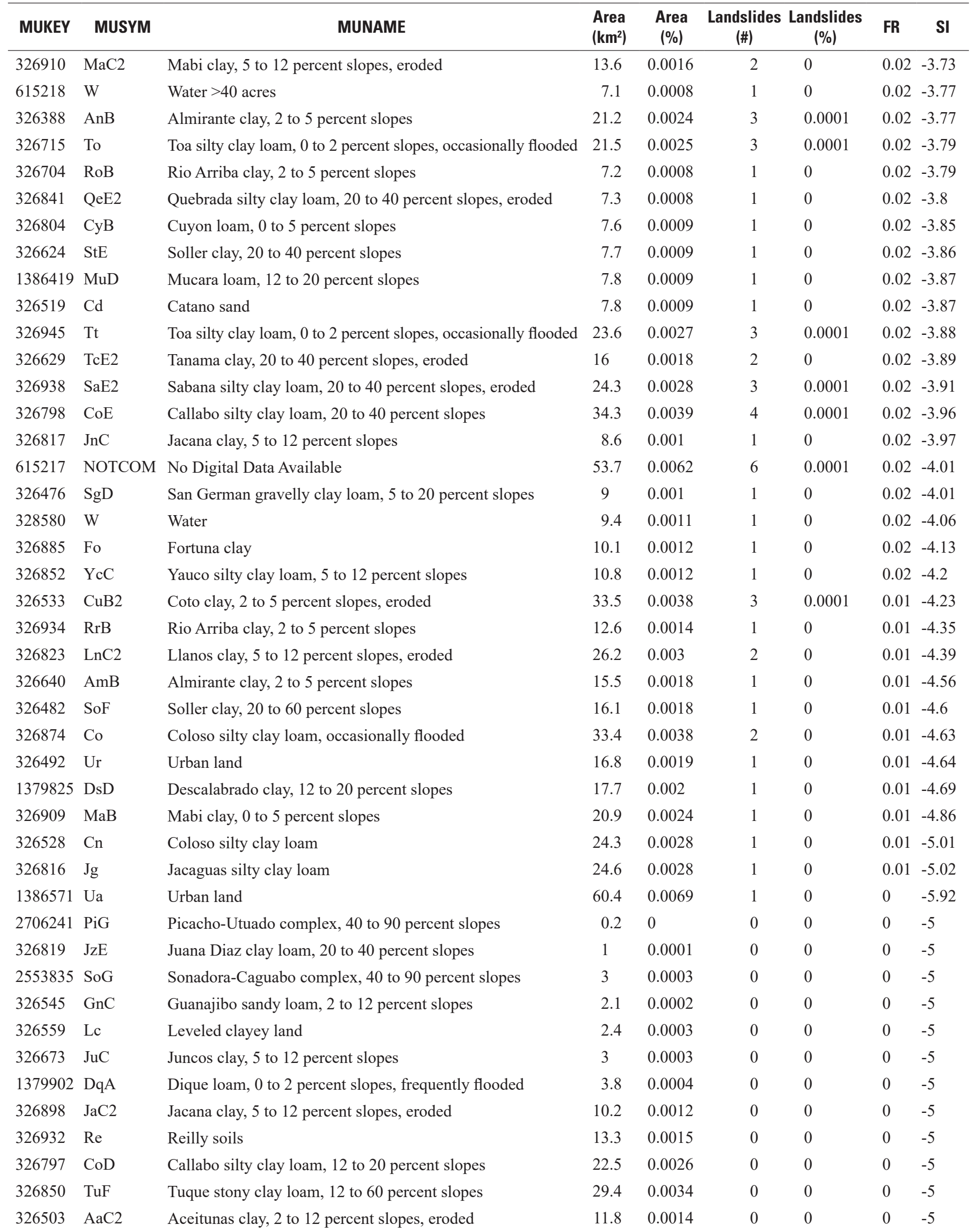




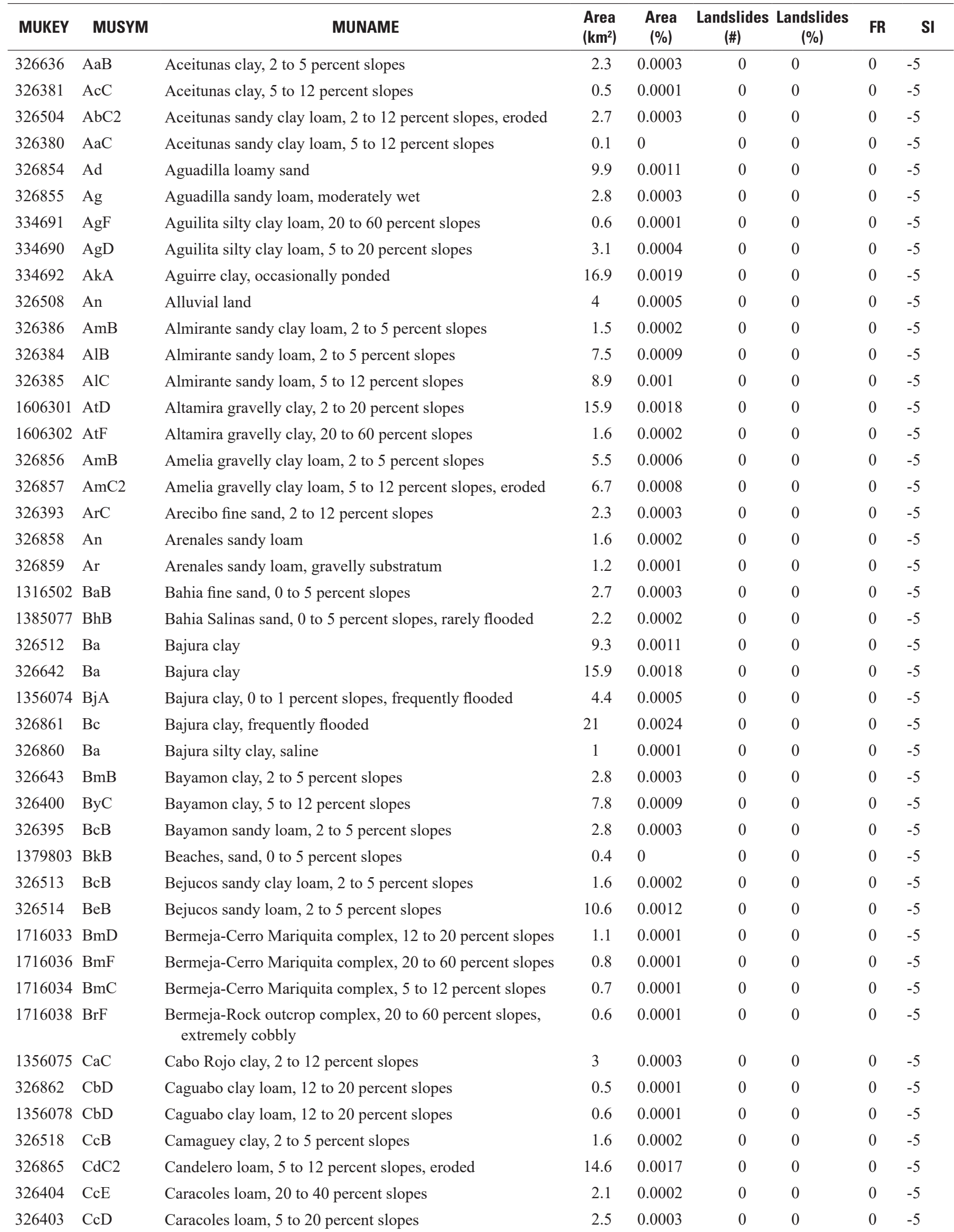




\begin{tabular}{|c|c|c|c|c|c|c|c|c|}
\hline MUKEY & MUSYM & MUNAME & $\begin{array}{l}\text { Area } \\
\left(\mathrm{km}^{2}\right)\end{array}$ & $\begin{array}{c}\text { Area } \\
(\%)\end{array}$ & $\begin{array}{l}\text { Landslides } \\
\text { (\#) }\end{array}$ & $\begin{array}{l}\text { Landslides } \\
(\%)\end{array}$ & FR & SI \\
\hline 326866 & $\mathrm{Ce}$ & Cartagena clay & 5.9 & 0.0007 & 0 & 0 & 0 & -5 \\
\hline 2023625 & $\mathrm{CgF}$ & Casabe clay, 20 to 60 percent slopes & 0.7 & 0.0001 & 0 & 0 & 0 & -5 \\
\hline 1884546 & $\mathrm{CgD}$ & Casabe clay, 5 to 20 percent slopes & 1.7 & 0.0002 & 0 & 0 & 0 & -5 \\
\hline 326406 & $\mathrm{Cf}$ & Catano sand & 2.7 & 0.0003 & 0 & 0 & 0 & -5 \\
\hline 1379802 & ChA & Catano sand, 0 to 2 percent slopes & 0.9 & 0.0001 & 0 & 0 & 0 & -5 \\
\hline 326520 & $\mathrm{Ce}$ & Catano sandy clay loam & 1 & 0.0001 & 0 & 0 & 0 & -5 \\
\hline 1716016 & $\mathrm{CkD}$ & Cerro Mariquita gravelly clay loam, 12 to 20 percent slopes & 1.8 & 0.0002 & 0 & 0 & 0 & -5 \\
\hline 1379810 & $\mathrm{CmB}$ & Coamo clay loam, 2 to 5 percent slopes & 0.2 & 0 & 0 & 0 & 0 & -5 \\
\hline 326522 & $\mathrm{Ch}$ & Coastal beach & 1.8 & 0.0002 & 0 & 0 & 0 & -5 \\
\hline 326407 & $\mathrm{Cg}$ & Coastal beaches & 0.9 & 0.0001 & 0 & 0 & 0 & -5 \\
\hline 326872 & $\mathrm{Cm}$ & Coastal beaches & 2.7 & 0.0003 & 0 & 0 & 0 & -5 \\
\hline 326409 & $\mathrm{ClE} 2$ & Colinas clay loam, 20 to 40 percent slopes, eroded & 10.4 & 0.0012 & 0 & 0 & 0 & -5 \\
\hline 326526 & $\mathrm{CmD}$ & Colinas cobbly clay loam, 12 to 20 percent slopes & 0.5 & 0.0001 & 0 & 0 & 0 & -5 \\
\hline 1379808 & $\mathrm{CoA}$ & Coloso clay, 0 to 2 percent slopes, occasionally flooded & 15.9 & 0.0018 & 0 & 0 & 0 & -5 \\
\hline 326875 & $\mathrm{Cr}$ & Coloso silty clay & 9.5 & 0.0011 & 0 & 0 & 0 & -5 \\
\hline 326654 & Cs & Coloso silty clay loam & 11 & 0.0013 & 0 & 0 & 0 & -5 \\
\hline 1386555 & $\mathrm{CtA}$ & $\begin{array}{l}\text { Cortada silty clay loam, } 0 \text { to } 2 \text { percent slopes, occasionally } \\
\text { flooded }\end{array}$ & 1 & 0.0001 & 0 & 0 & 0 & -5 \\
\hline 1716031 & $\mathrm{CuF}$ & Costa-Pitahaya complex, 20 to 60 percent slopes & 17.8 & 0.002 & 0 & 0 & 0 & -5 \\
\hline 1716030 & $\mathrm{CuD}$ & Costa-Pitahaya complex, 5 to 20 percent slopes & 6.1 & 0.0007 & 0 & 0 & 0 & -5 \\
\hline 326532 & $\mathrm{CtB} 2$ & Cotito clay, 0 to 5 percent slopes, eroded & 2.7 & 0.0003 & 0 & 0 & 0 & -5 \\
\hline 326419 & $\mathrm{CtB}$ & Coto clay, 2 to 5 percent slopes & 0.2 & 0 & 0 & 0 & 0 & -5 \\
\hline 326420 & $\mathrm{CtC}$ & Coto clay, 5 to 12 percent slopes & 0 & 0 & 0 & 0 & 0 & -5 \\
\hline 326534 & $\mathrm{CuC} 2$ & Coto clay, 5 to 12 percent slopes, eroded & 16.3 & 0.0019 & 0 & 0 & 0 & -5 \\
\hline 326535 & $\mathrm{CvB}$ & Coto sandy clay loam, 2 to 5 percent slopes & 0.7 & 0.0001 & 0 & 0 & 0 & -5 \\
\hline 326877 & $\mathrm{DaC}$ & Daguao silty clay loam, deep variant, 2 to 12 percent slopes & 1.3 & 0.0001 & 0 & 0 & 0 & -5 \\
\hline 1379822 & DeD & Delicias clay, 5 to 20 percent slopes & 2 & 0.0002 & 0 & 0 & 0 & -5 \\
\hline 326880 & DeE2 & Descalabrado clay loam, 20 to 40 percent slopes, eroded & 14.3 & 0.0016 & 0 & 0 & 0 & -5 \\
\hline 326879 & 43801 & Descalabrado clay loam, 5 to 12 percent slopes, eroded & 3.4 & 0.0004 & 0 & 0 & 0 & -5 \\
\hline 1379824 & $\mathrm{DsC}$ & Descalabrado clay, 2 to 12 percent slopes & 8 & 0.0009 & 0 & 0 & 0 & -5 \\
\hline 326662 & $\mathrm{Dm}$ & Dique loam & 1.3 & 0.0001 & 0 & 0 & 0 & -5 \\
\hline 326663 & Dr & Durados sandy loam & 1.3 & 0.0001 & 0 & 0 & 0 & -5 \\
\hline 1884721 & EdD & El Descanso-Hoconuco complex, 5 to 20 percent slopes & 0.1 & 0 & 0 & 0 & 0 & -5 \\
\hline 1690984 & EpD & El Papayo gravelly clay loam, 12 to 20 percent slopes & 4.6 & 0.0005 & 0 & 0 & 0 & -5 \\
\hline
\end{tabular}




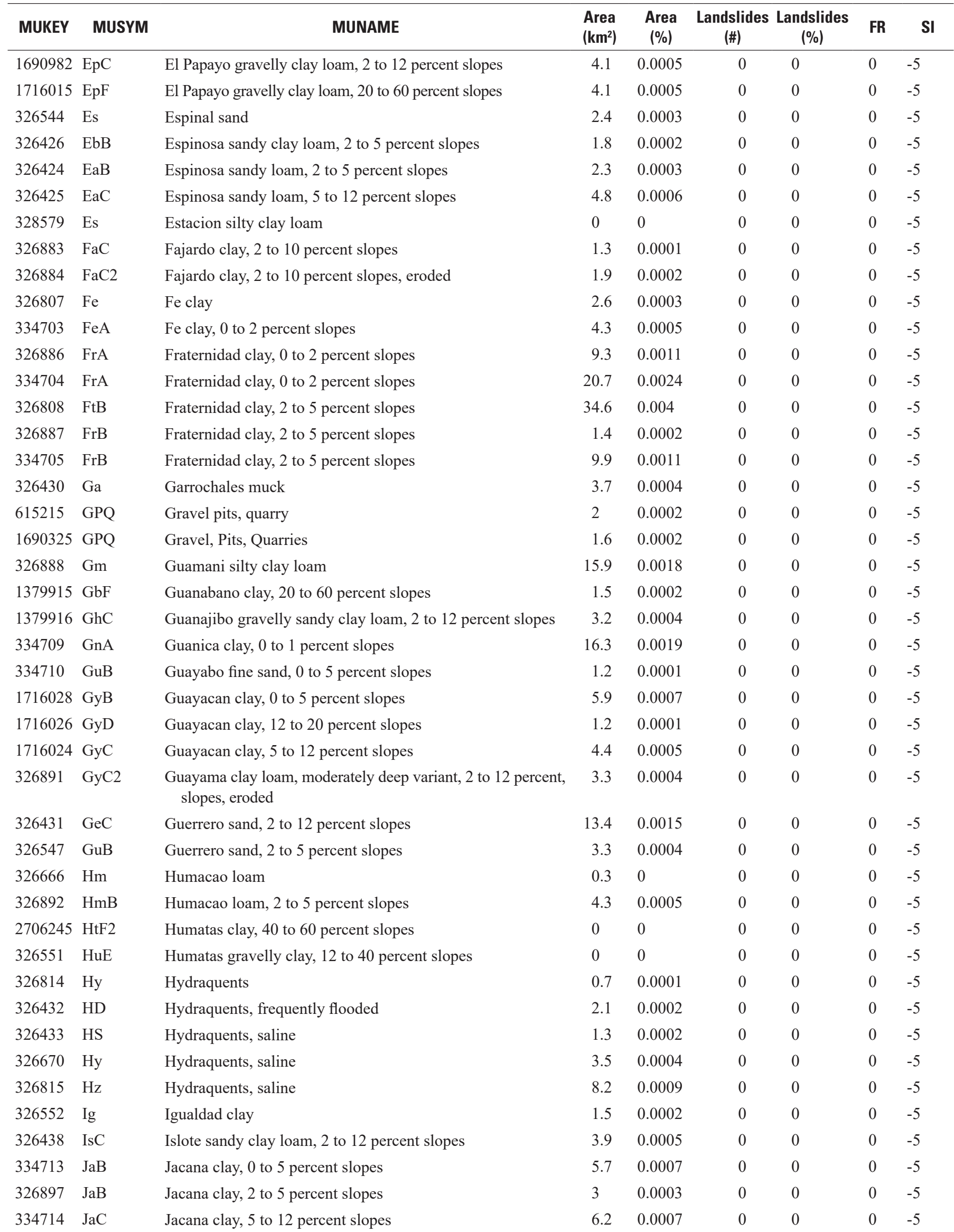




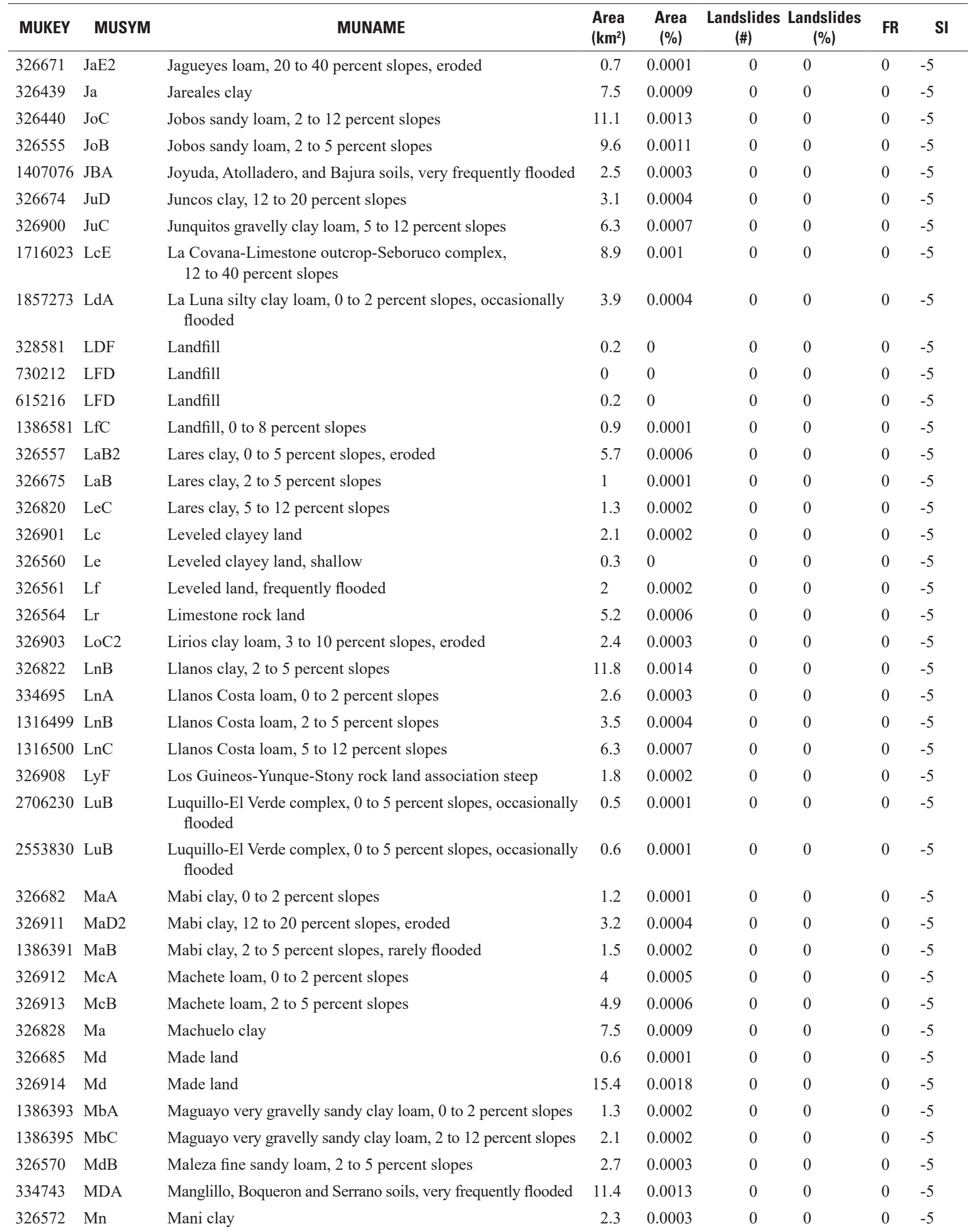




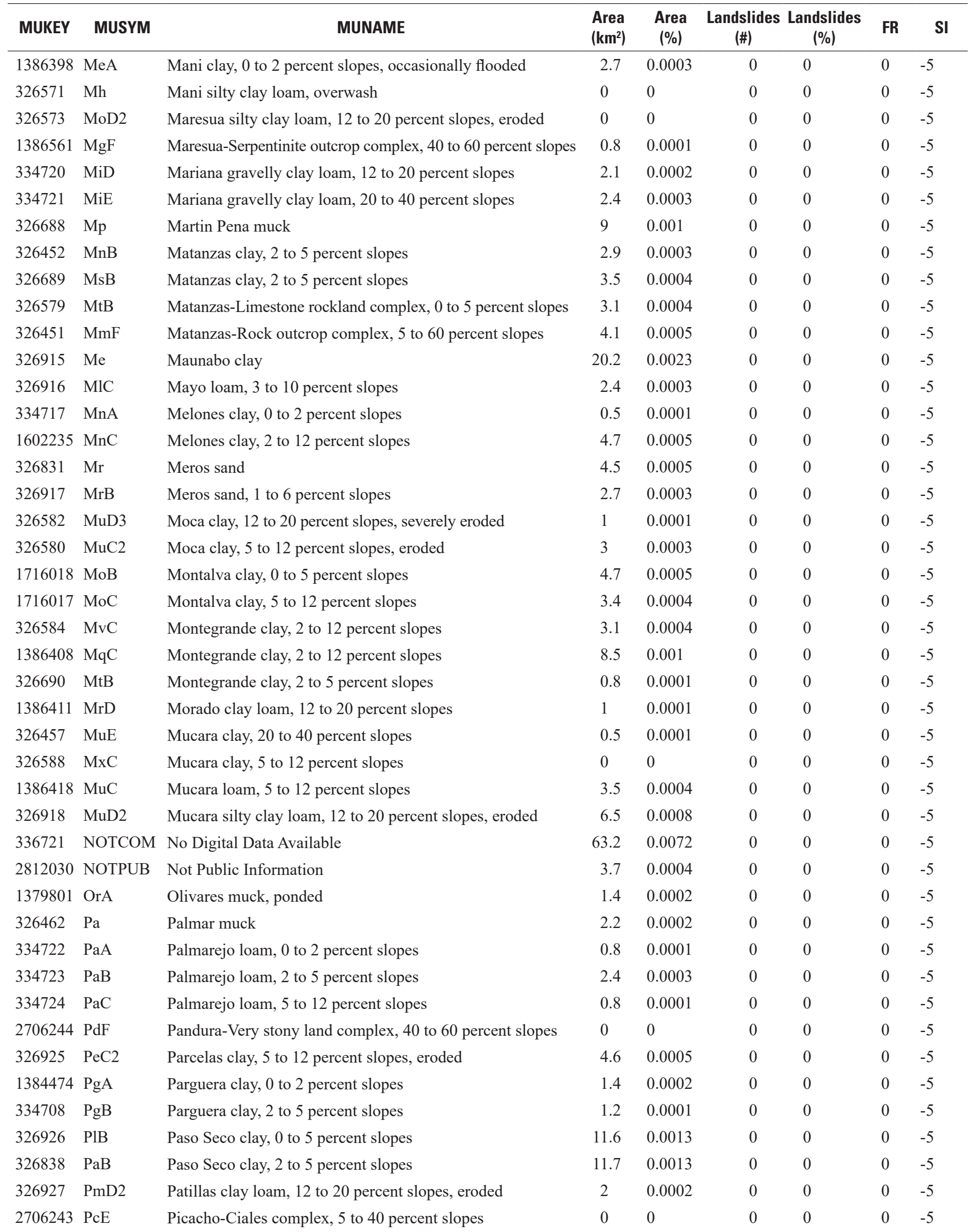




\begin{tabular}{|c|c|c|c|c|c|c|c|c|}
\hline MUKEY & MUSYM & MUNAME & $\begin{array}{l}\text { Area } \\
\left(\mathbf{k m}^{2}\right)\end{array}$ & $\begin{array}{c}\text { Area } \\
(\%)\end{array}$ & $\begin{array}{l}\text { Landslides } \\
\text { (\#) }\end{array}$ & $\begin{array}{l}\text { Landslides } \\
(\%)\end{array}$ & FR & SI \\
\hline 326929 & $\mathrm{Pn}$ & Pinones silty clay & 3.6 & 0.0004 & 0 & 0 & 0 & -5 \\
\hline 1887151 & PsG & $\begin{array}{l}\text { Pitahaya-Limestone outcrop-Seboruco complex, } \\
60 \text { to } 90 \text { percent slopes }\end{array}$ & 1.7 & 0.0002 & 0 & 0 & 0 & -5 \\
\hline 326930 & Po & Poncena clay & 9.8 & 0.0011 & 0 & 0 & 0 & -5 \\
\hline 326931 & $\mathrm{PrC} 2$ & Pozo Blanco clay loam, 5 to 12 percent slopes, eroded & 1.9 & 0.0002 & 0 & 0 & 0 & -5 \\
\hline 334728 & $\mathrm{PzB}$ & Pozo Blanco clay, 0 to 5 percent slopes & 0.7 & 0.0001 & 0 & 0 & 0 & -5 \\
\hline 334730 & $\mathrm{PzD}$ & Pozo Blanco clay, 12 to 20 percent slopes & 0.2 & 0 & 0 & 0 & 0 & -5 \\
\hline 1386547 & $\operatorname{ReA}$ & Reilly sandy loam, 0 to 2 percent slopes, frequently flooded & 5.5 & 0.0006 & 0 & 0 & 0 & -5 \\
\hline 326933 & $\mathrm{Rp}$ & Reparada clay & 0.9 & 0.0001 & 0 & 0 & 0 & -5 \\
\hline 326602 & R1B & Rio Lajas sand, 2 to 5 percent slopes & 4.5 & 0.0005 & 0 & 0 & 0 & -5 \\
\hline 326707 & RpE2 & Rio Piedras clay, 20 to 40 percent slopes, eroded & 3.3 & 0.0004 & 0 & 0 & 0 & -5 \\
\hline 326605 & $\mathrm{Rr}$ & Riverwash & 0 & 0 & 0 & 0 & 0 & -5 \\
\hline 326472 & $\mathrm{Rr}$ & Rock outcrop, sandstone & 0.6 & 0.0001 & 0 & 0 & 0 & -5 \\
\hline 1386549 & RoD & Rosario silty clay, 12 to 20 percent slopes & 1.2 & 0.0001 & 0 & 0 & 0 & -5 \\
\hline 326475 & $\mathrm{SaB}$ & Sabana Seca clay, 2 to 5 percent slopes & 5.3 & 0.0006 & 0 & 0 & 0 & -5 \\
\hline 326710 & $\mathrm{ScB}$ & Sabana Seca clay, 2 to 8 percent slopes & 3 & 0.0003 & 0 & 0 & 0 & -5 \\
\hline 334734 & $\mathrm{SdD}$ & San German cobbly clay loam, 5 to 20 percent slopes & 0.2 & 0 & 0 & 0 & 0 & -5 \\
\hline 326611 & $\mathrm{ScB}$ & San German cobbly sandy loam, 0 to 5 percent slopes & 0.1 & 0 & 0 & 0 & 0 & -5 \\
\hline 326609 & $\mathrm{SaD}$ & San German gravelly clay loam, 12 to 20 percent slopes & 14.2 & 0.0016 & 0 & 0 & 0 & -5 \\
\hline 326610 & $\mathrm{SaE}$ & San German gravelly clay loam, 20 to 40 percent slopes & 8.3 & 0.001 & 0 & 0 & 0 & -5 \\
\hline 1407068 & $\mathrm{SgF}$ & San German-Duey complex, 20 to 60 percent slopes & 18.7 & 0.0021 & 0 & 0 & 0 & -5 \\
\hline 1407070 & $\operatorname{SgD}$ & San German-Duey complex, 5 to 20 percent slopes & 1 & 0.0001 & 0 & 0 & 0 & -5 \\
\hline 326479 & $\mathrm{SnC}$ & Santa Clara clay, 2 to 12 percent slopes & 5 & 0.0006 & 0 & 0 & 0 & -5 \\
\hline 326613 & $\mathrm{SeB}$ & Santa Clara silty clay loam, 2 to 5 percent slopes & 2.1 & 0.0002 & 0 & 0 & 0 & -5 \\
\hline 334737 & $\mathrm{SiA}$ & Santa Isabel clay, 0 to 2 percent slopes & 2 & 0.0002 & 0 & 0 & 0 & -5 \\
\hline 326615 & $\mathrm{Sn}$ & Santoni clay & 3.5 & 0.0004 & 0 & 0 & 0 & -5 \\
\hline 1379905 & SoC & Seboruco silty clay loam, 2 to 12 percent slopes & 2 & 0.0002 & 0 & 0 & 0 & -5 \\
\hline 326846 & $\mathrm{Se}$ & Serrano sand & 3.4 & 0.0004 & 0 & 0 & 0 & -5 \\
\hline 326623 & StD & Soller clay, 12 to 20 percent slopes & 4 & 0.0005 & 0 & 0 & 0 & -5 \\
\hline 326621 & StB & Soller clay, 2 to 5 percent slopes & 0 & 0 & 0 & 0 & 0 & -5 \\
\hline 326622 & $\mathrm{StC}$ & Soller clay, 5 to 12 percent slopes & 1.3 & 0.0002 & 0 & 0 & 0 & -5 \\
\hline 326620 & $\mathrm{SsE} 2$ & Soller cobbly clay, 20 to 40 percent slopes, eroded & 1.6 & 0.0002 & 0 & 0 & 0 & -5 \\
\hline 334739 & $\mathrm{SsB}$ & Sosa sandy loam, 2 to 5 percent slopes & 6.5 & 0.0007 & 0 & 0 & 0 & -5 \\
\hline
\end{tabular}




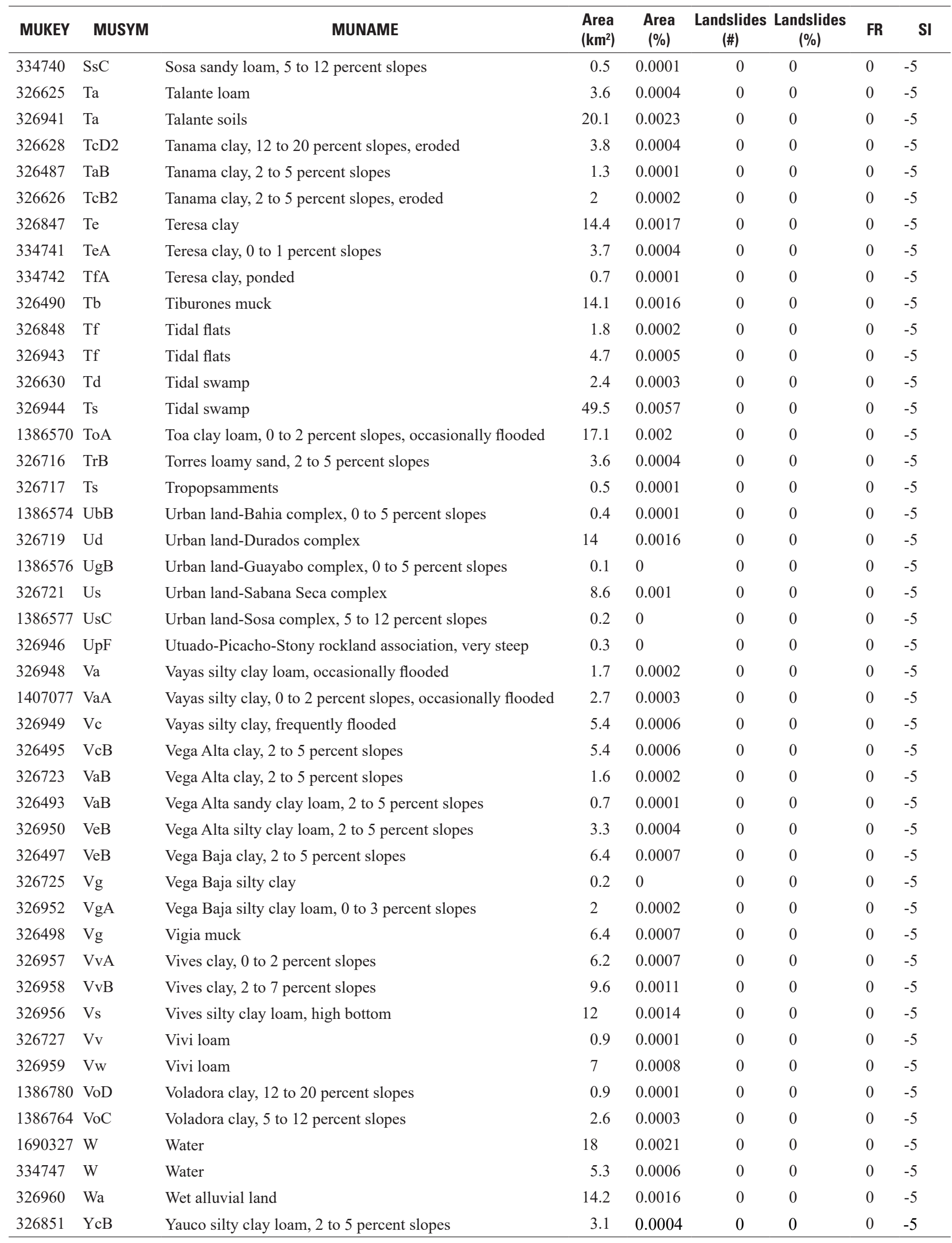




\section{$\frac{\mathbb{2}}{3}$}

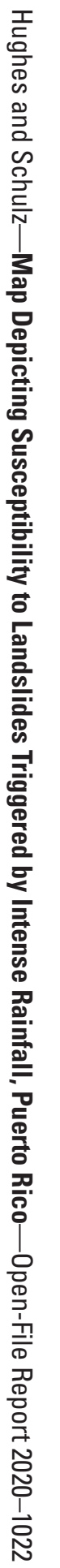

